\title{
ENVIRONMENTAL ASSESSMENT:
}

Cassia County, Idaho

\section{Raft River Geothermal Project Pilot Plant}

DOE/EA- 0090

DE85 012616

September 1979

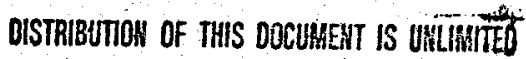




\section{DISCLAIMER}

This report was prepared as an account of work sponsored by an agency of the United States Government. Neither the United States Government nor any agency Thereof, nor any of their employees, makes any warranty, express or implied, or assumes any legal liability or responsibility for the accuracy, completeness, or usefulness of any information, apparatus, product, or process disclosed, or represents that its use would not infringe privately owned rights. Reference herein to any specific commercial product, process, or service by trade name, trademark, manufacturer, or otherwise does not necessarily constitute or imply its endorsement, recommendation, or favoring by the United States Government or any agency thereof. The views and opinions of authors expressed herein do not necessarily state or reflect those of the United States Government or any agency thereof. 


\section{DISCLAIMER}

Portions of this document may be illegible in electronic image products. Images are produced from the best available original document. 


\section{SUMMARY}

The action assessed here ts the construction and operation of a 5- to 6-MW(e) (gross) geothermel pllot plant in the Raft River Valley of southern Idaho. This project was originally planned as a thermal test loop using a turbine simulator valve for which an environmental assessment (DOE/EA-0008, Merch 1978) was previously published. The test loop facility (without the simulator valve) is now under construction. The current enviromental assessment addresses the complete system (hereinafter referred to as the pilot plant) including the addition of a turbinegenerator and 1 ts associated swltching gear (authorized by Congress in 1978) In place of the simulator valve. The addition of the turbinegenerator will result in a net production of 2.5 to $3.5 \mathrm{MW}(e)$ with a comensurate reduction in waste hest to the cooling tower and will require the upgrading of existing trassuission lines for offaite delivery of generated power.

The following sumary is largely a recepitulation of enviromentel impacts Identifled in the earlier assessment, the only additions being features directly related to power generation capab1lity. Construction of the facility will require disturbance of approximately 20 ha (50 ecres) for the facility Itself and approximately 22.5 ha (57 acres) for construction of drilling pads and ponds, pipelines, and roads. Existing transmission lines will be upgraded for the utility oystem interface. Interference with alternste land uses w1Il be minimal. Loss of wildIIfe hab1tet will be acceptable, and D.S. F1sh and Wildilfe Service recomendations for protection of raptor nesting sites, riparian vegetat10n, and other important habltats will be observed. During construction, nolse levels may reach 100 dBA at 15 m (50 ft) from well sites, but wildilfe and local residents should not be significantly affected if extended construction 15 not carried out within $0.5 \mathrm{~km}$ ( 0.3 miles) of residences or sensitive wildilfe habitat. Provision will be made to protect personnel on the sites from excessive nolse levels according to standard practices and procedures defined by OSEA and DOE. Water use during construction will not be large and impacts on competing uses are unlikely. Laying of pipelines under the Raft River will be done 
in a manner which will minfmize siltation and will be cleared with the Idaho Department of Water Resources. Because the constructton project w111 not employ a large number of Raft River Valley residents, and few construction workers will need to find housing in the valley, socioeconomic impacts should be small.

Revegetation will reduce the land area comitted to project activities to 8 ha (20 acres) during the operation period, thereby reducing the loss of wildilfe habitat and competition with other land uses. Afr pollution by the facility should not be sufficlent to affect humans, plants, or wildiffe. The effects of water withdrawal and injection are difficult to predict because the extent of connection between aquifers is poorly defined. Potential effects include decline in the water table, ground surface subsidence, contamination of shallow aquifers, and induced seismicity. Monitoring programs have been established to detect each of these effects. Operation of the facillty will bring a few new residents to the Raft River Valley but no significant changes In the socioeconomic character of the area are expected.

The most likely accident resulting from operation of the facility Is uncontrolled release of geothermal fluids due to a plpeline rupture, loss of control at the wellhead (blowout), or fallure of the well casing. Such accidents could result in destruction of vegetation and contamination of air, surface water, and groundwater. 
CONIENTS

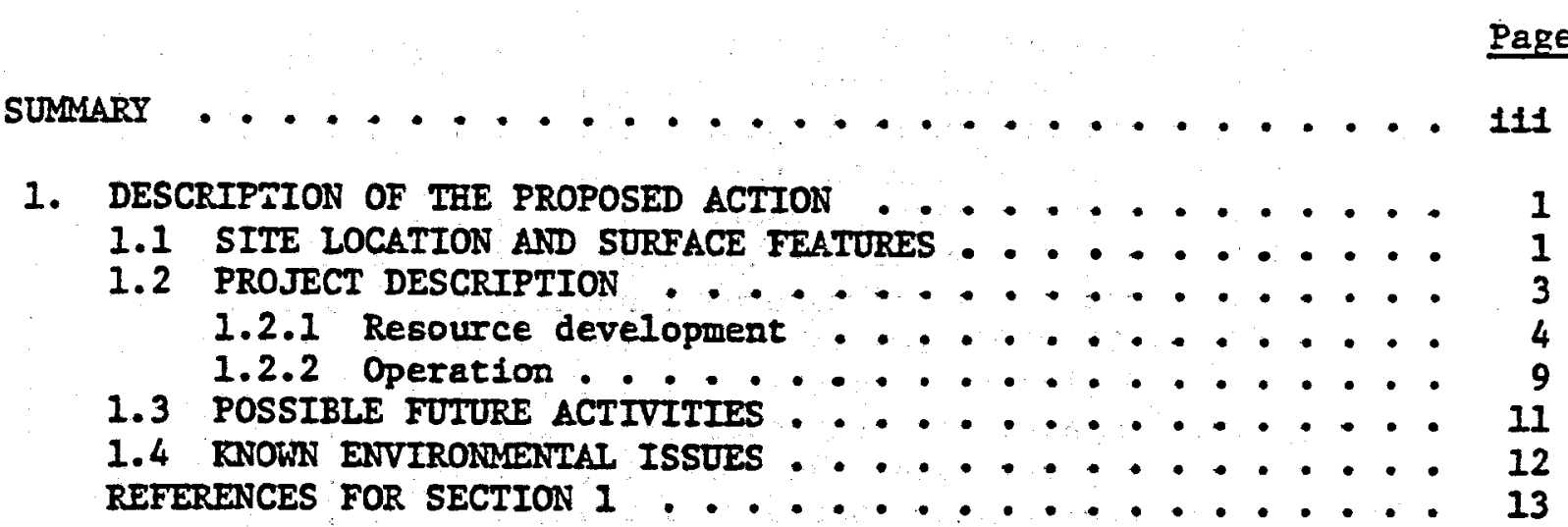

2. DESCRIPTION OF THE EXISTING ENVRIONMIENT . . . . . . . . 15

2.1 GEOLOGY, SOIIS, AND GEOTHERMAL RESOURCES . . . . . . 15

2.1 .1 Geology . . . . . . . . . . . . 15

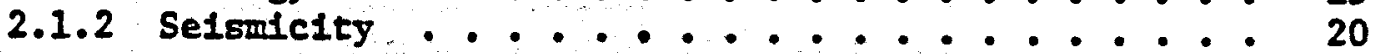

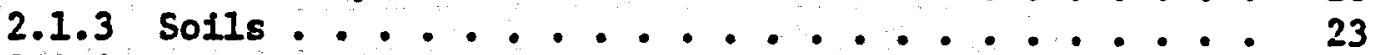

2.1 .4 Geothermal resources ............ . . 27

2.2 HYDROLOGY AND WATER QUALITY . . . . . . . . . . 29

2.2 .1 Surface water............... 29

2.2 .2 Groundwater . . . . . . . . . . 33

2.3 ATMOSPEERIC CHARACTERISTICS . . . . . . . . 36

2.3 .1 Climate . . . . . . . . . . 36

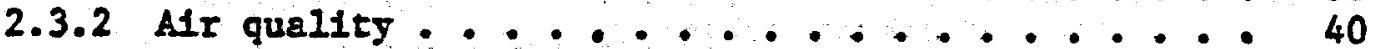

2.4 NOISE . . . . . . . . . 43

2.4.1 Nolse characteristics of the site ....... 45

2.4 .2 No1se regulations ............... 45

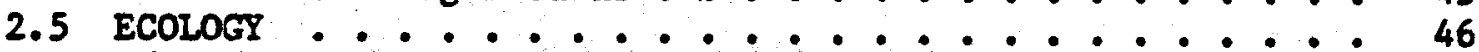

2.5 .1 Terrestrial ecology .............. 46

2.5 .2 Aquatic ecology ............... 49

2.5.3 Endangered spectes............. 50

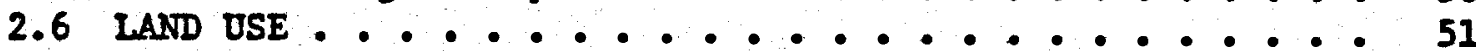

2.6.1 Prime and unique farmlands .......... 53

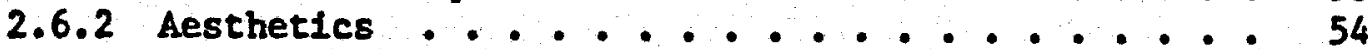

2.7 WATER USE . . . . . . . . . . . . . 54

2.8 DEMOGRAPHY AND SOCIOECONOMICS ........... 56

2.9 HISTORIC AND ARCHAEOLOGIC SITES AND NATURAI

LANDMARRS . . . . . . . . ........ 59

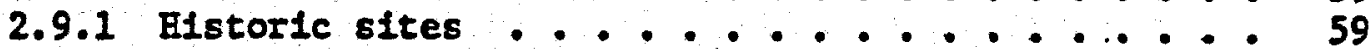

2.9.2 Archaeologic sites ............. 61

2.9.3 Naturel landmarks . . . . . . . . . . 62

REFERENCES FOR SECTION 2 .................. 63

3. POTENTIAL ENTIRONMENTAL IMPACTS . . . . . . . . . 67

3.1 IMPACTS OF DEVELOPMENT ............... 67

3.1.1 Geological impacts .............. 67

3.1 .2 Impacts on water quality ........... 67 
3.1.3 Impacts on air quality . . . . . . . . 69

3.1 .4 Ecological impacts . . . . . . . . 71

3.1 .5 Impacts on land use ............ 73

3.1 .6 Impacts on water use . . . . . . . . . 76

3.1.7 Socloeconomic Impacts . . . . . . . . 77

3.1.8 Impacts on historlcal and archaeological

resources and natural landmarks ........ 78

3.2 IMPACTS OF OPERATION ............................... 78

3.2 .1 Geological impacts ................ 78

3.2 .2 Impacts on water quality .............. 82

3.2 .3 Impacts on alr quality ........... 83

3.2 .4 Ecological Impacts . . . . . . . . . 84

3.2.5 Impacts on land use . . . . . ..... 85

3.2 .6 Impacts on water use ............. 86

3.2 .7 Socioeconomic impacts . . . . . . . . 87

3.2.8 Impacts on historical and archaeologic

resources and natural landmarks ......... 88

3.3 SITE RESTORATION .................. 88

3.4 ACCIDENTS ..................... 89

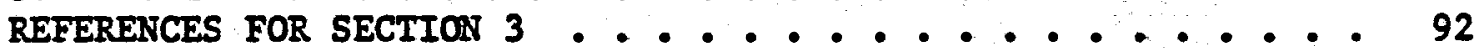

4. COORDINATION WITH FEDERAL, STATE, AND LOCAI PLANS . . . . . 95

5. ALTERRATIVES . . . . . . . . . . . . . . . . . 97

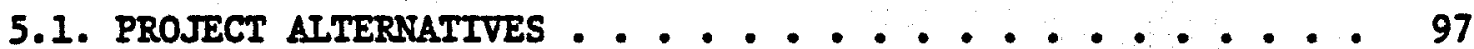

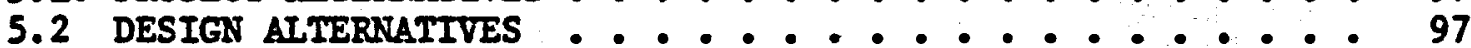

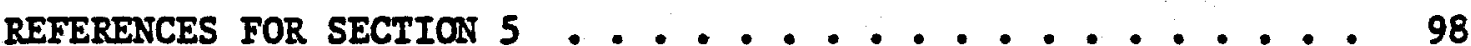

APPENDIX A ......................... A-1 


\section{DESCRIPTION OF THE PROPOSED ACIION}

The proposed action addressed by this Environmental Impact Assessment (EIA) is the design, construction, and operation of 8 5- to 6-MW(e) (gross) pilot plant for evaluating the geothermal energy potential of moderate-temperature hydrothermal resources. The Department of Energy (DOE) plans to construct and operate this fac1lify to evaluate the geothermal fluid properties and the heat exchanger characteristics for a dual-boiling binary hest transfer system in which a low-bolling fluid such as a fluorocarbon or hydrocarbon is used to extract heat from the geothermal fluid and produce electricity. The following description is basically the same as the one provided in a previous environmental assessment (DOE/EA-0008) for the originally planned thermal test loop facllity. The only changes or additions relate to the turbine-generator and its anclllary installations.

\subsection{SITE LOCATION AND SURFACE FEATURES}

The Raft River Geothermal Development is located in Cassia County in southcentral Idaho, near the Dteh-Idaho border (FIg.1.1). An appl1cation to withdraw approximately 2000 ha (5000 acres) of land adminlstered by the Bureau of Land Manggement (BLM) for the purposes of geothermal development has been submitted and is currently under review by the BLM. The project has recelved use permits for the individual activities while the withdrawal permit 16 being considered.

For the purposes of this report, it 15 assumed that al1 development will occur within the boundarles of the area, which is referred to in this report as the geothermal withdrawal. This area Includes the 2000 ha (5000 acres) of BLM land plus approximately 1500 ha (3640 acres) of privately owned land. All but 227 ha (560 acres) of the withdrawn land lies in Township 15 South, Range 26 East (Boise Meridian). The latitude and longitude of the Raft Rtver Geothermal Exploration well No. 1 (RRGE-1) near the center of the withdrawal are $42^{\circ} 06^{\prime} 09^{\prime \prime} \mathrm{N}$ and $113^{\circ} 23^{\prime} 01^{\prime \prime}$ $W$, respectively. The Universal Transverse Mercator (UTM) coordinates for this well are $4,664,951$ in $N$ and 302,598 m $\mathrm{E}$. The nearest sizable 


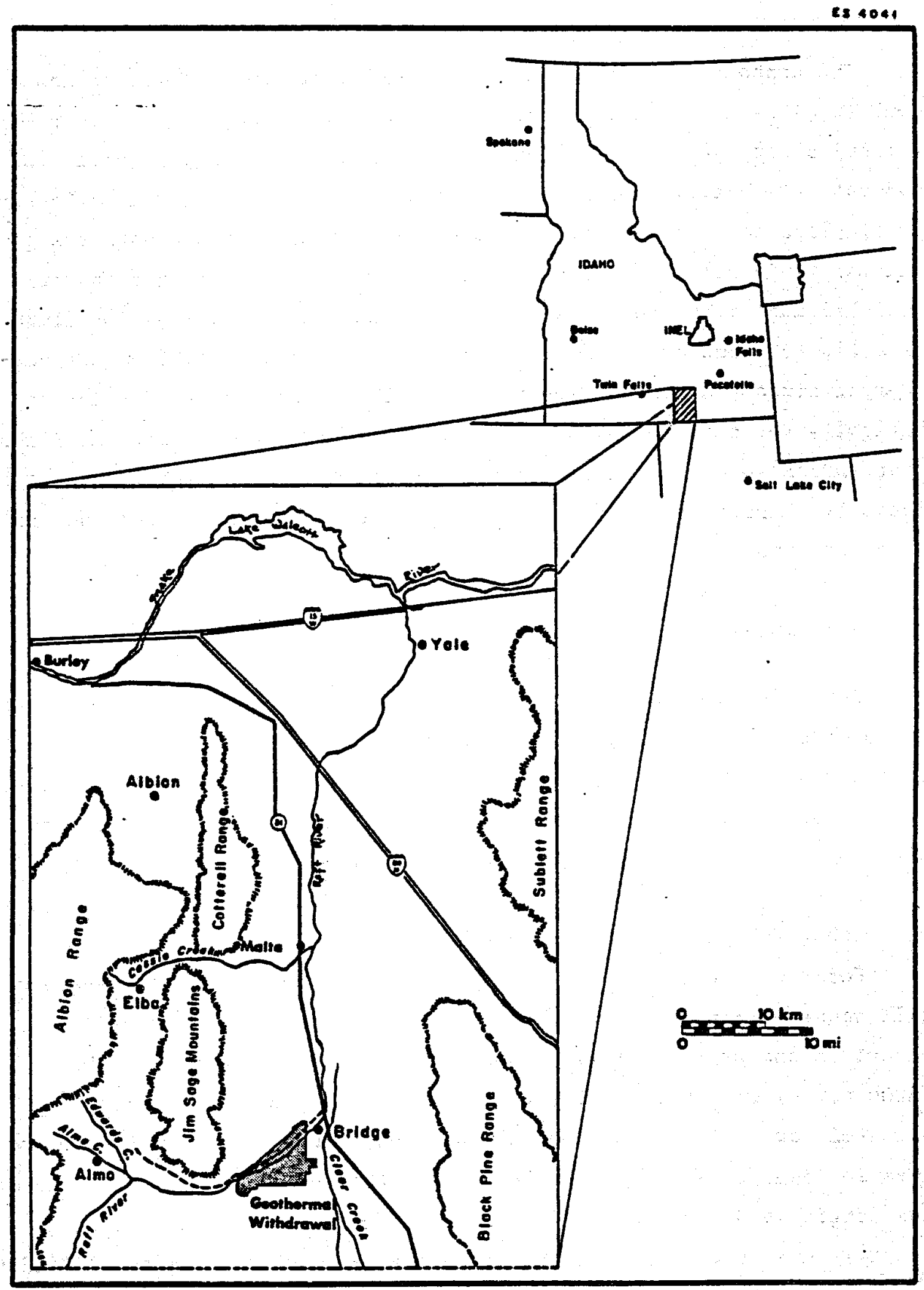

Fig. 1.1. Map showing location of the geothermal withdrawal area. Source: Idaho National Engineering Laboratory, Enviromental Report, Raft River Thermal Loop Facility, TREE-1144, 1977. 
population centers are Malta (population 196), $24 \mathrm{~km}$ (15 miles) to the north, and Burley (populat1on 8,820$), 84 \mathrm{~km}$ (52 miles) to the northwest. Salt Lake City, Otah is approximately 200 bo (125 miles) to the southeast and Bolse, Idaho is $342 \mathrm{~km}$ (210 miles) to the northwest.

The geothermal withdrawal is located in the drainage of the Raft River, a tributery of the Snake River. The elevation of the valley floor in the goethermal withdrawal is $1950 \mathrm{~m}(4800 \mathrm{ft})$. The valley is surrounded by five mountain ranges: Jim Sage - $2453 \mathrm{~m}$ (8048 ft), Reft River - $3016 \mathrm{~m}(9892 \mathrm{ft})$, Black PIne - $2860 \mathrm{~m}$ (9385 ft), Sublett $2600 \mathrm{~m}(8500 \mathrm{~m})$, and Cotterell Range $-2167 \mathrm{~m}$ (7110 ft).

\subsection{PROJECT DESCRIPTION}

The proposed project will consist of up to seven geothermal fluld wells for production and Infection of geothermal fluids. These wells will be connected to a heat trensfer loop by underground piping. The heat transfer loop w1ll be capable of transferring $40 \mathrm{MW}(t)$ of heat from the goethermel flulds to a secondary isobutane fluld system. (Other flulds such as propane, pentane, water, and fluorocarbons may be used as the secondary fluld during the life of the facllity.) The vaporized binary fluid will expand through the turbine-generator system to produce a gross output of 5 to $6 \mathrm{MW}(e)$. Net power to the utility grid will be 2.5 to $3.5 \mathrm{MW}(\mathrm{e})$.

The Inttial objectives of the project are to complete the well drillIng and facility construction activities for operation to start at the beginning of 1980. Later objectives will be to operate the facility for approximately five years (perhaps on a cost-sharing basis between DOE and a ut1lity group) to effect resource development, component and system testing, and heat transfer capability studies for the binary cycle. It Is also expected the cooled geothermal fluids released from the plant will be used in nonelectric heat applications such as aquaculture and ground heating.

Th1s EIA will evaluate the project in two phases: resource development and plant operation. 


\subsubsection{Resource development}

Initial exploration activities were conducted by the Raft River Rural Electrical Cooperative, Idaho National Engineering Laboratory, and the U.S. Geological Survey (USGS) from 1971 to 1974. Since then, exploration activities have been confined to microselsmic, heat flow, and chemical studies.

\subsubsection{Drilling and flow-testing}

These exploration activities resulted in the drilling of four test wells by ERDA (the subjects of previous enviromental assessments). These wells (RRGE-1, $-2,-3,-4$ ) and the USGS exploration wells (USGS-1, $-2,-3,-4,-5)$ are shown on F1g. 1.2. In order to meet a geothermal fluid flow requirement of approximately 140 liters/sec (2250 gpm), four production wells will be necessary. All geothermal flulds not evaporated in the cooling tower or diverted to other uses will be injected into three infection wells. This brings the total number of wells to seven, of which three have yet to be drilled.

Drilling will be performed with a standard rotary drill rig $52 \mathrm{~m}$ (170 ft) high. This operation will require the construction of access roads and a level drilling pad for each well drilled. Access raods will be constructed to use existing roadways when possible. New roads will require the clearing and graveling of 0.2 ha ( 0.5 acres) per well. The drilling pad will require a cleared and level area of approximately 0.8 ha ( 2 acres) that will be compacted and graveled.

A reserve pit with a volume of $3700 \mathrm{~m}^{3}$ ( 3 acre-ft) will be provided at each well site. This pit will be used to hold the fluids from drilling and flow-testing. Figure 1.3 shows a typical drill site plan indicating the auxilliary facillties required to support drilling operations.

The drilling operations to be used are typical of current geothermal drilling practice. A hole of decressing diameter will be drflled, and a conductor plpe and surface casing will be installed as a part of the drilling operation. The annulus between the bore hole and casing will be properly cemented to prevent geothermal fluids from contaminating 
ES-4119

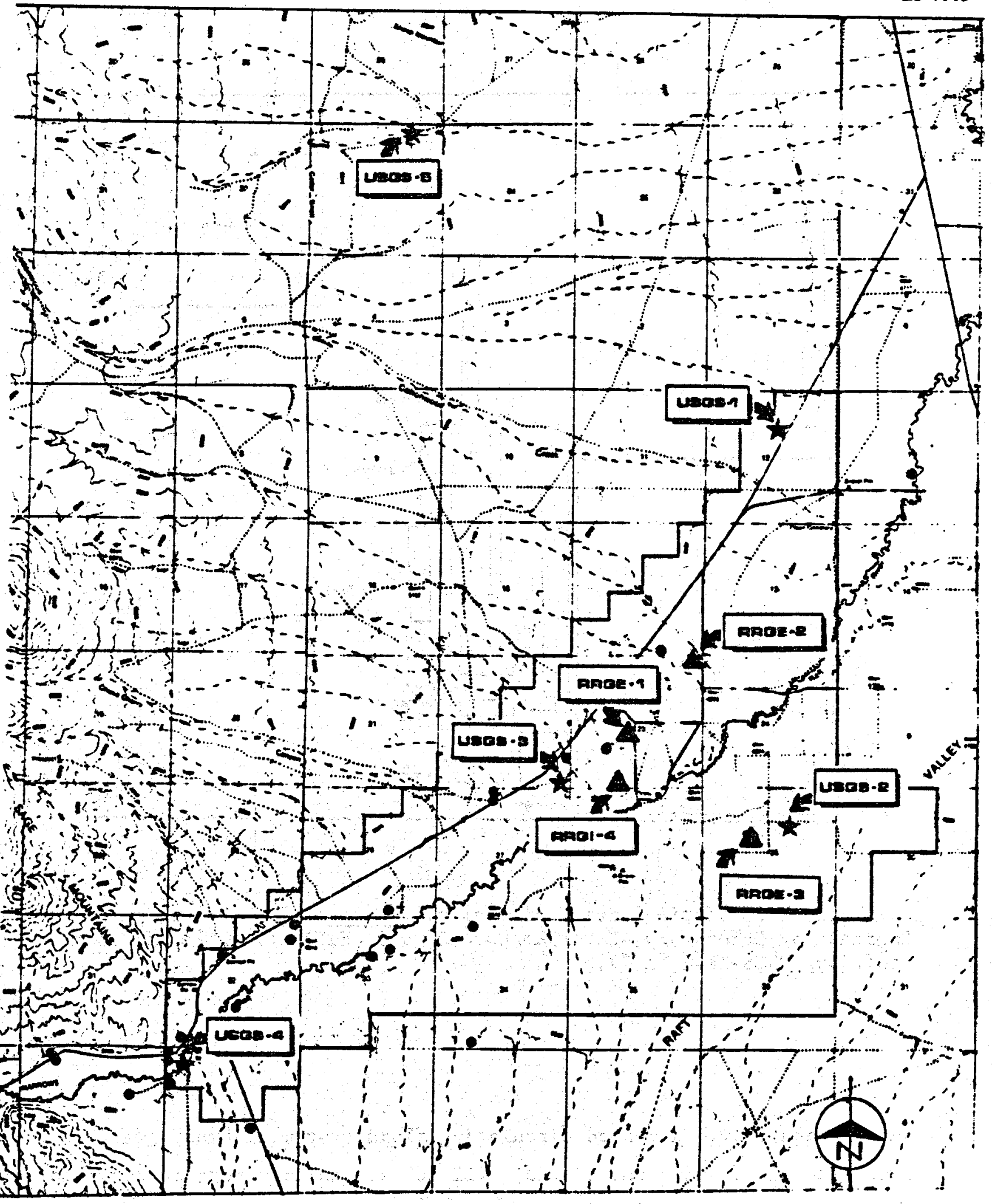

F1g. 1.2. Map showing location of RRGE and USGS wells. Source: Idaho Nat1onal Engineering Laboratory, Environental Report, Raft River Thermal Loop Facility, TREE-1144, 1977. 
ES-4120

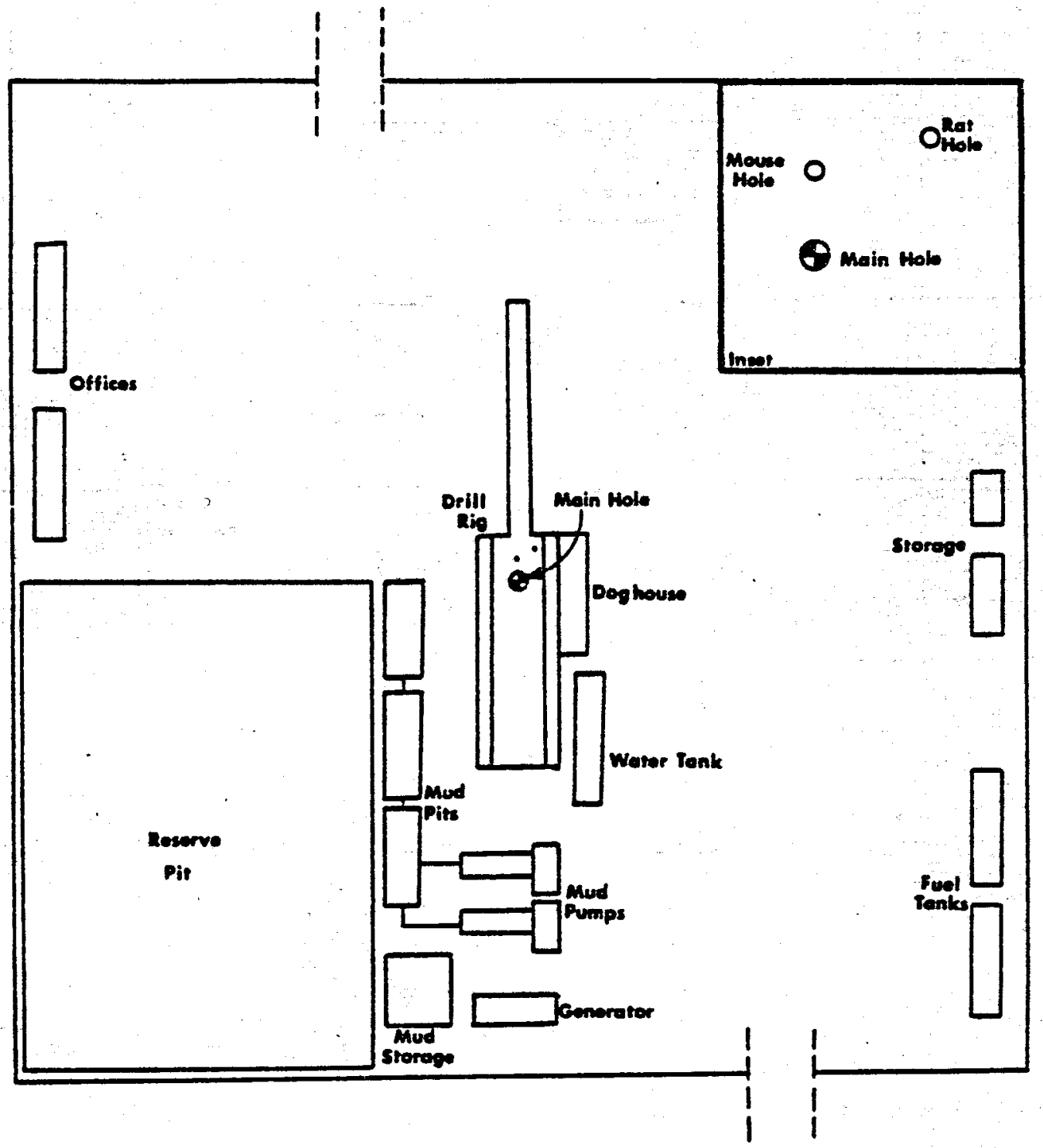

Fig. 1.3. Typical drill site plan. Source: Idaho National Engineering Laboratory, Enviromental Report, Raft River Thermal Loop Facility, TREE-1144, 1977.

shallow aquifers. A closed circulating fluid system of "mud" (water, bentonite clay, and caustic soda) will be used to transport cuttings to the surface and to cool and Iubricate the drill string for the first $500 \mathrm{~m}$ (1600 ft). Mud or water w111 be used between 500 and $1300 \mathrm{~m}$ 
(4300 ft), and only water w1ll be used below $1300 \mathrm{~m}$ (4300 ft). Approximately 25,000 I1ters $(6300 \mathrm{gal})$ of water per day w11l be required for the "mud."

Flow-testing of wells w1ll be performed after completion of the well to clean out the well and to evaluate the resource. All fluids generated during flow-testing will either be injected into another well or collected in the reserve pit for evaporation and seepage.

\subsubsection{Construction}

While the production and injection wells are being confirmed, the construction of the pilot plant will begin. This will involve the fabrication of piping to interconnect the wells and the fibrication of the pllot plant faclilty.

Aboveground steel geothermal fluid supply lines will be $20 \mathrm{~cm}$ (8 in.) and $25 \mathrm{~cm}(10 \mathrm{ln}$.$) in diameter; burled asbestos concrete lines$ will be $25 \mathrm{~cm}$ (10 in.), $30 \mathrm{~cm}$ (12 in.), $35 \mathrm{~cm}$ (14 in.), and $40 \mathrm{~cm}$ (16 in.) In diameter. The lines will be burled a minimum of $1 \mathrm{~m}$ (3 ft) deep with expansion loops at 60-m (200-ft) Intervals. One or more we11s w1ll be on the other side of the Raft RIver, requiring that geothermal Iines cross the river. These ines will be burled in the streambed at a single crossing location in accordance with Idaho Department of Water Resources requirements. Construction at the river crossIng may require several days. The production 1 ines will be insulated with a minimum thickness of $5 \mathrm{~cm}$ ( 2 in.) of industrial insulation material. The average length of line will be $1.6 \mathrm{~km}$ ( 1 mile). Fluid flow will be augumented by downhole pumps in the wells. Individual Iines will be manifolded into a $30.5-\mathrm{cm}(12-$ in. $)$ diameter leader before they enter the pilot plant.

The pilot plant itself will consist of a fenced area of 2.4 he ( 6 acres) containing the heat exchanger equipment, turbine-generator and assoclated electrical swltchgear, control and support bulldings, cooling tower, evaporative ponds, and roadways. A general arrangement is shown in Fig. 1.4. Bulldings will be prefabricated metal structures on concrete foundations and will be painted in shades that blend with the 
ES-4121

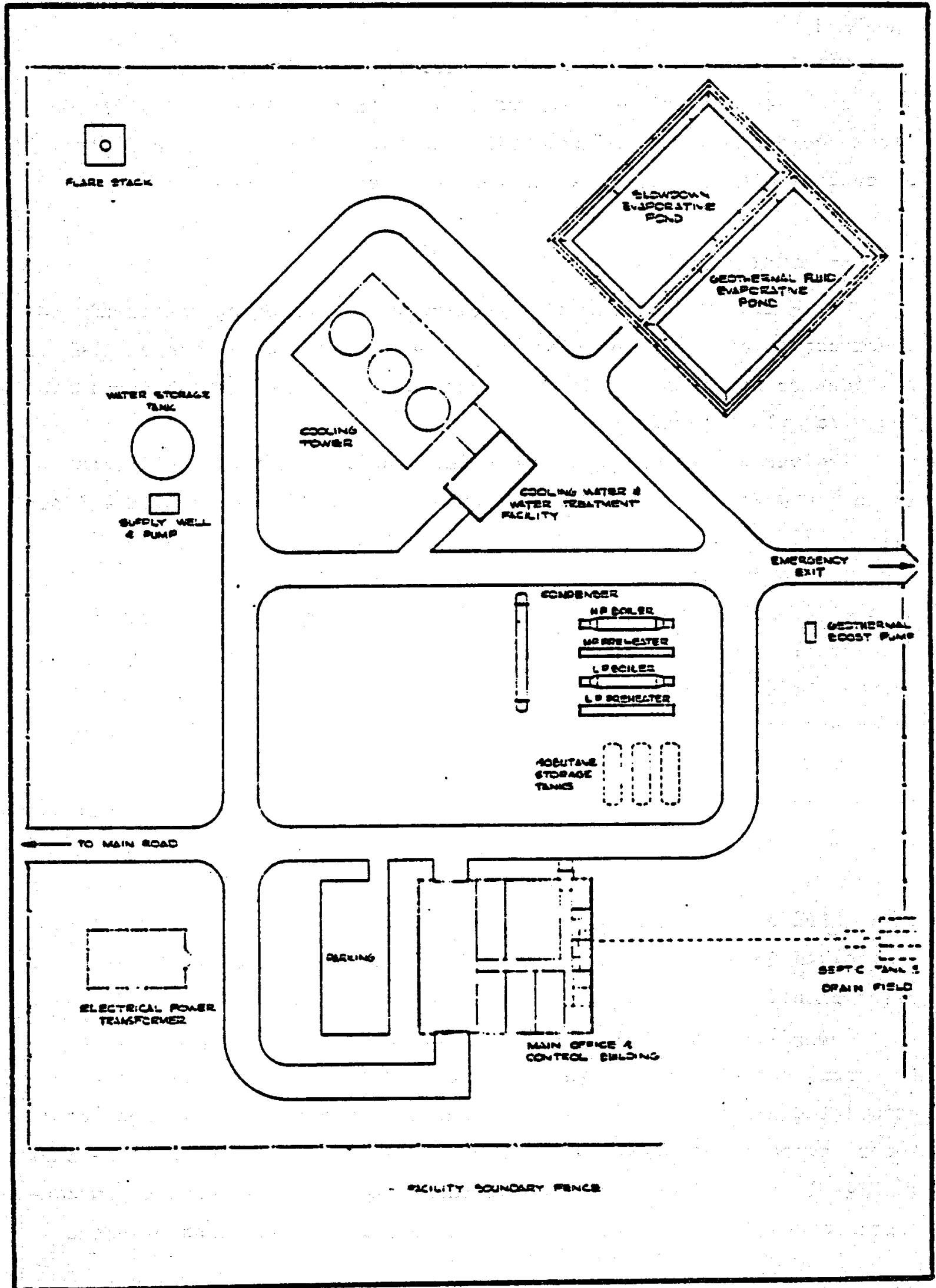

Fig. 1.4. Site plan. Source: Idaho National Engineering Laboratory, Environmental Report, Raft River Thermal Loop Facility, TREE-1144, 1977. 
surrounding landscape. All structures will be designed to meet the Uniform Bullding Code requirements for seismic zone III.

The cooling tower will be an induced draft wooden structure $24 \times 21 \times 15 \mathrm{~m}(80 \times 70 \times 50 \mathrm{ft})$ with two $75-\mathrm{kw}(100-\mathrm{hp})$ fans.

The pllot plant facility consists of four heat exchangers, a condenser, the turbine-generator system, assoclated fluid piping and controls for the goethermal fluid and the binary fluld, and blowdown evaporative ponds to collect all wastes not injected with the geothermal fluid.

The Initial binary fluid will be 1sobutane. Storage vessels for the fluid will be underground within the fenced area. Isobutane will be Isolated from the main plant as much as possible by locating the heat exchangers on the lowest ground within the site. The main plant will be located on a terrace deposit about $5 \mathrm{~m}(15 \mathrm{ft})$ above the heat exchangers. Since isobutane is heavier than air, it would be unlikely to come in contact with other facilities in the event of a leak at the heat exchangers. The piping and equipment for the 1sobutane will be specifically designed and manufactured to safely contain the fluld under all normal operating conditions and for abnormal temperature cycles that might result from fast shutdown. Other fluids possible in the binary cycle are propane, refrigerant No. $31 / 114$ ( 75 mole $\% \mathrm{R}-31$ and 25 mole $\%$ R-114), pentane, and water.

The generating gystem w111 consist of a dual entry turbine and a generator. In addit1on, there are associated control equipment, transformers, relays, and assoclated electrlcal swltchgear.

Existing transmission lines of approximately $5 \mathrm{~km}$ ( $3 \mathrm{miles}$ ) in length will be used to carry the electricity produced into the power grid. These IInes w111 be upgraded auring the spring of 1978 to $14.4 / 24.9 \mathrm{kV}$. The IInes tie Into the $138-\mathrm{kV}$ main IIne at the Bridge substation northesst of the plant. Electrical power will be supplied to the facillty, when required, by these upgraded transmission lines.

\section{2 .2 Operation}

Plant operation will normally consist of flowing geothermal fluld through one side of the heat exchangers, bolling the binary fluld contained 
on the other side, flowing the vaporized binary fluld through the turbinegenerator to produce electricity, and then flowing the binary fluid to the condenser and back to a storage tank.

\subsubsection{Geothermal fluid}

Eot geothermal fluld will be supplied by the wells at a rate of 140 liters/sec (2250 $\mathrm{gpm})$ and w111 pass through the heat exchangers in the thermal loop. The inlet design conditions are $1310 \mathrm{kPa}$ (190 psi) and $143^{\circ} \mathrm{C}\left(290^{\circ} \mathrm{F}\right)$, and the exit conditions are $1000 \mathrm{kPa}$ (145 psi) and $<63^{\circ} \mathrm{C}\left(145^{\circ} \mathrm{F}\right)$. The cooled geothermal fluld is pumped at a rate of from 120 to 13211 ters/sec ( 1900 to $2100 \mathrm{gPm}$ ) to the injection wells, where injection pumps are capable of handling up to $15811 \mathrm{ters} / \mathrm{sec}(2500 \mathrm{gpm})$. The system is designed to bypass the heat exchangers if necessary, in which case the infected fluid would be near the inlet conditions.

\subsubsection{Binary Eluid}

The binary fluld system is based on isobutane. A dual-boiling Rankine cycle wlll be capable of extracting $40 \mathrm{MW}(t)$ [equivalent to $5 \mathrm{MW}(e)]$ from the geothermal fluld. The isobutane is completely enclosed in a flow loop separate from the geothermal fluid; only heat is exchanged between them. The geothermal heat causes the binary fluid to boil in the heat exchangers, from which vapor is conducted to the turbine-generator, and then to a condenser. The condensed fluid is then returned to the heat exchangers by pumps to repeat the cycle.

The condenser for the binary fluid will require a cooling water circulation rate of about 840 1iters/sec $(13,000 \mathrm{gpm})$. The cooling water will be circulated through the cooling tower, where maximum total evaporation and blowdown are about 25 Iiters/sec (420 gpm). Makeup water for these losses will come from the geothermal fluids prior to infection. The treated cooling tower blowdown of 7 11ters/sec (115 gpm) will be reinjected with the geothermal fluld if water quality regulations will permit reinjection of the treated effluent. 


\section{2 .2 .3 Other fluids}

A separate well for fresh water will supply fire and sanitary water for the facility.

IIquid wastes consisting of floor drains, fystem flushes, hot water dumps, and all other nonchemical drains will be routed to the evaporative pond. In addition, if the geothermal monftoring system detects binary fluid in the geothermal fluld, it will be routed to this pond also. All other IIquid wastes will be routed to a sealed blowdown pond, except for cooling tower blowdown which will be routed to a treatment facility. Sludge from the blowdown treatment facllity will be transferred to a landfill in accordance with state and local requirements.

\subsubsection{Generating system}

The generating system w1l consist of a dual entry turbine and a generator. The turbine-generator w1ll have a comblned gross output rating of nominally $5 \mathrm{MW}(e)$ in sumer and $6 \mathrm{MW}(\mathrm{e})$ in winter. Net output of the plant, which will go into the power grid, will be approximately 2.5 to $3.5 \mathrm{MW}(\mathrm{e}) .1$

\subsection{POSSIBLE FUTURE ACTIVITIES}

The only important addition to the pllot plant presently under consideration is a 500-kW direct contact heat exchanger system. This add-on feature would not significantly increase the demand for geothermal fluid, and there is 11ttle likelihood of a significantly Increased environmental impact.

Some of the conceivable future activities (not necessarily DOE related) are: (1) blomass ( 5011 warming) experiments, (2) aquaculture (flsh farm) experiments, (3) gasohol experiments, in which sugar beets would be converted to ethanol by using a geothermal heat source, and (4) the drying of potato waste products for consumption by fish or livestock. These activities may intermittently use geothermal fluids airectly from existing wells or after it passes through the pilot plant. None of 
these activities would require signiflcantly increased fluid product lon. Also construction and operational activities would be limited.

An in-progress aquaculture experiment is a good example of the level of activity to be expected from projects of the type 11sted above. This project is not related to the p1lot plant and will be terminated (Fall 1979) prior to plant startup. The aquaculture facility consists of a series of raceways, fish ponds, and cooling system. It requires 7 Itters $/ \mathrm{sec}(110 \mathrm{gpm})$ of geothermal fluld at $27^{\circ} \mathrm{C}\left(80^{\circ} \mathrm{F}\right)$. This amounts to about $10 \%$ of the production from a single geothermal well. With the presence of a pllot plant no additional geothermal flutd would be required because refect water from the plant could be used.

Privately owned commercial geothermal-electric power generation in the Raft River region is also conceivable if the pllot plant proves the technical and economic feasibility of such projects. The enviromental impacts of comercial power generation would be substantially greater than that for the proposed pllot plant. Much larger well flelds, site construction, and new transmission lines would be required, and impacts on groundwater and the Raft River would have to be reconsidered.

Because of the similarity of the currently proposed factlity and possible future activities, some sharing of wells, pipelines, and transmission lines may be possible; otherwise, a proportional increase in enviromental effects resulting from this project would be expected.

\subsection{KNOWN ENVIRONMENTAI ISSUES}

Environmental concerns relative to the geothermal profect have been expressed by the U.S. Fish and Wildilfe Service (USFWS) and by residents of the Raft River Valley. In a memorandum to the BIM District Office in Burley, Richard Fisher of the USIWS expressed concern for the preservation of the following fish and wildiffe resources: (1) the Cassia Creek f1shery, (2) riparian vegetation, (3) wlldife watering areas, (4) antelope kldding areas, (5) sage grouse strutting grounds, (6) raptor nesting areas, and (7) ground squirrel colonies (Appendix A).

On February 26, 1977, members of the Raft River Electric Co-op were surveyed to determine their feelings about geothermal development in the 


\section{DESCRIPTION OF THE EXISTING ENVIRONMENT}

The proposed action will be accomplished within the reglon typified by the enviroment described in this section. A general description of the region and a detailed description of the site will be presented with respect to geology, terrestrial ecology, aquatic ecology, rare and endangered species, demography, and socloeconomics.

\subsection{GEOLOGY, SOILS, AND GEOTEERMAL RESOURCES}

\section{1 .1 Geology}

\subsubsection{Structure}

The Raft River Basin is a graben bounded by normal faults (FIg. 2.1). It is flanked on the west by the Jin Sage anticline (a broad, gentle upwarp) and on the east and south by low-angle thrust sheets consisting of Paleozolc and Mesozolc strata which overlie Precambrian metamorphic and igneous rocks. The strata in the thrust sheets are moderately to strongly deformed. 1

The Raft River Basin is thought to possess elements of both the Jim. Sage and eastern structural styles (gentle folds and grabens, and complex folds and low angle thrusts, respectively) as shown in FIg. 2.1 . The latter structural style is belleved to be terminated on the north by The Narrows structure and on the west by the Bridge fault (F1g. 2.2). The Narrows structure and normal faults, wuch as the Bridge, are thought to provide the structural control for geothermal resources.

Cenozolc strate, Including Plelstocene fanglomerates, are offset by numerous normal faults that parallel the east, west, and south margins of the Raft River Basin (FIg. 2.1). Based on gravity data the three faults having the greatest displacement are: (1) the north-trending Bridge fault, (2) an unnamed fault along the western margin of the Black Plne Mountains, and (3) the east-west-trending Naf fault. The latter fault has no surface expression.

The faults show downard displacement with dip toward the center of the basin. Precambrian rocks were encountered at depths between 1400 


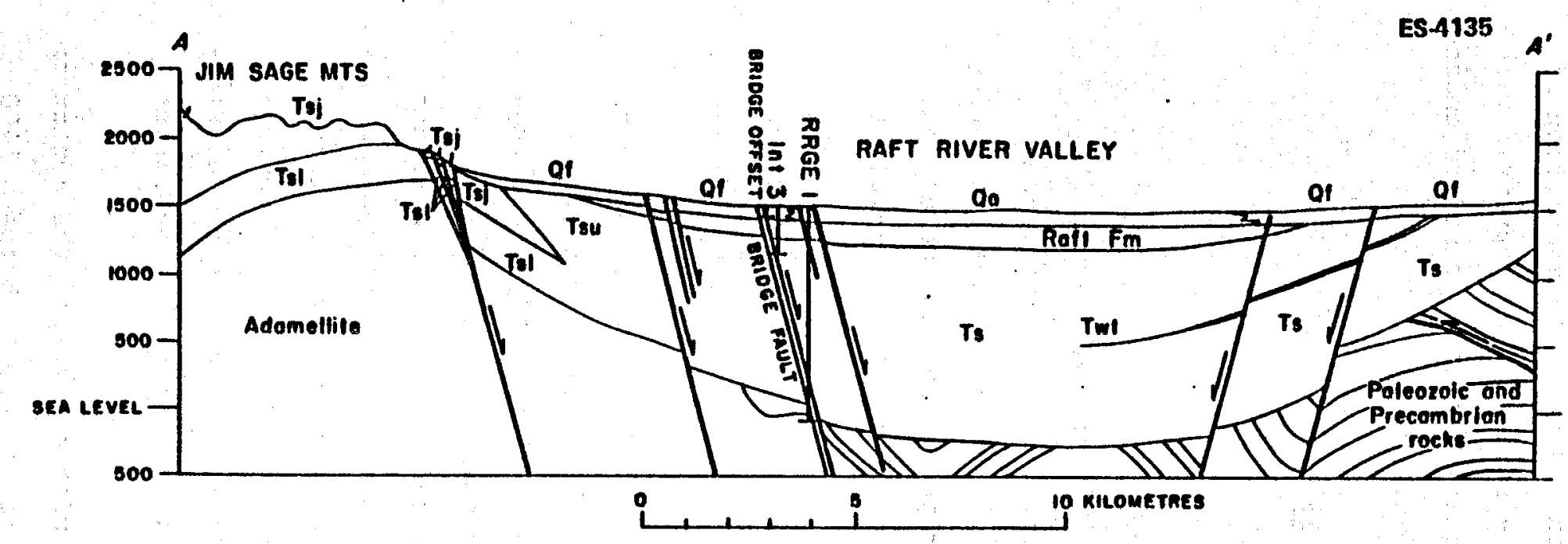

CORRELATION OF MAP UNITS

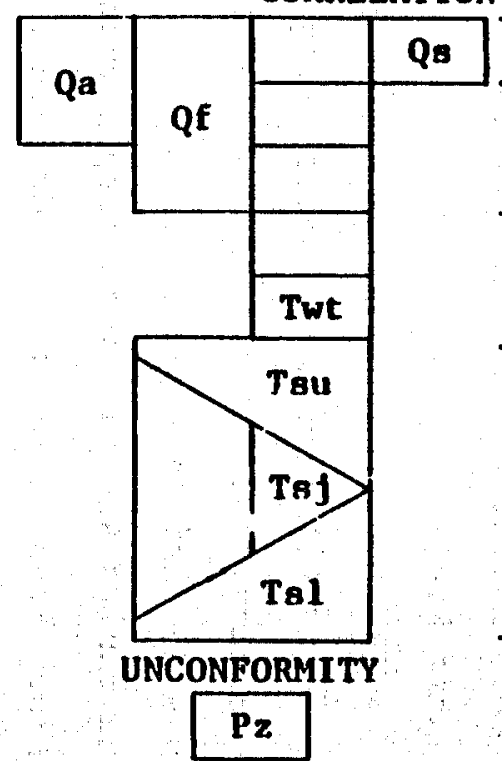

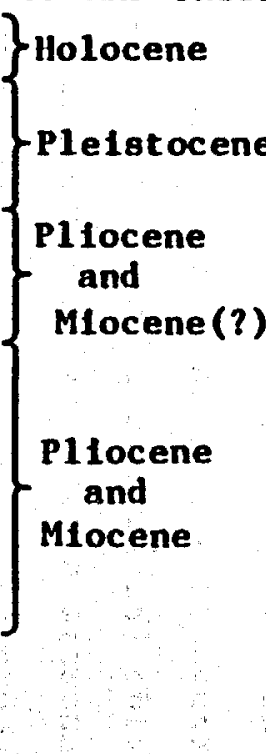

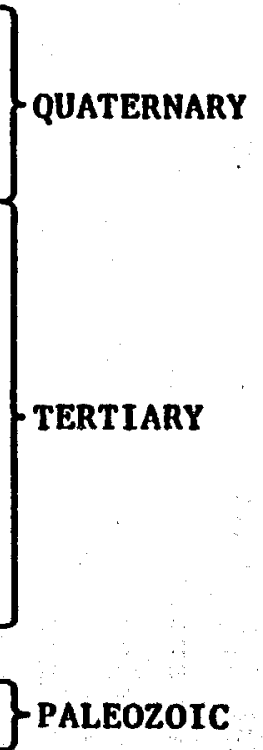

LIST OF STRUCTURE SECTION UNITS

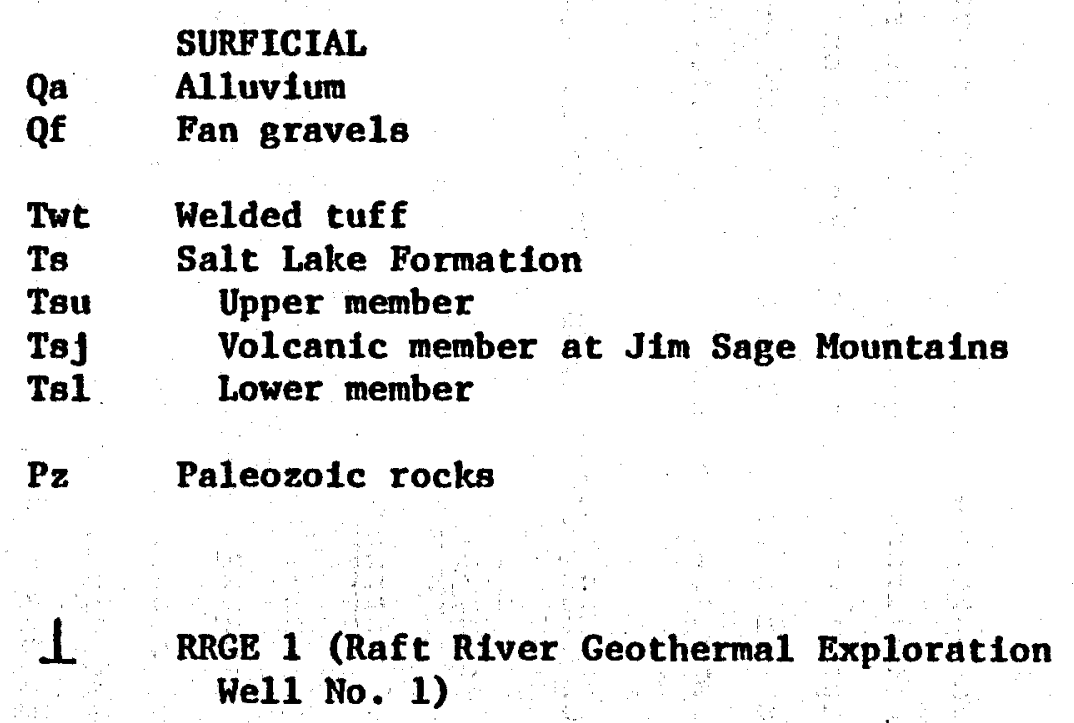

F1g. 2.1. Structure section perpendicular to axis of Raft RIver Valley. Source: P. L. Will1ams et al., Geology and Geophysics of the Southern Raft River Valley Geothermal Area, Idaho, U.S.A., U.S. Geological Survey Open File Report 75-322, Denver, Colo., 1975. 
ES 4122

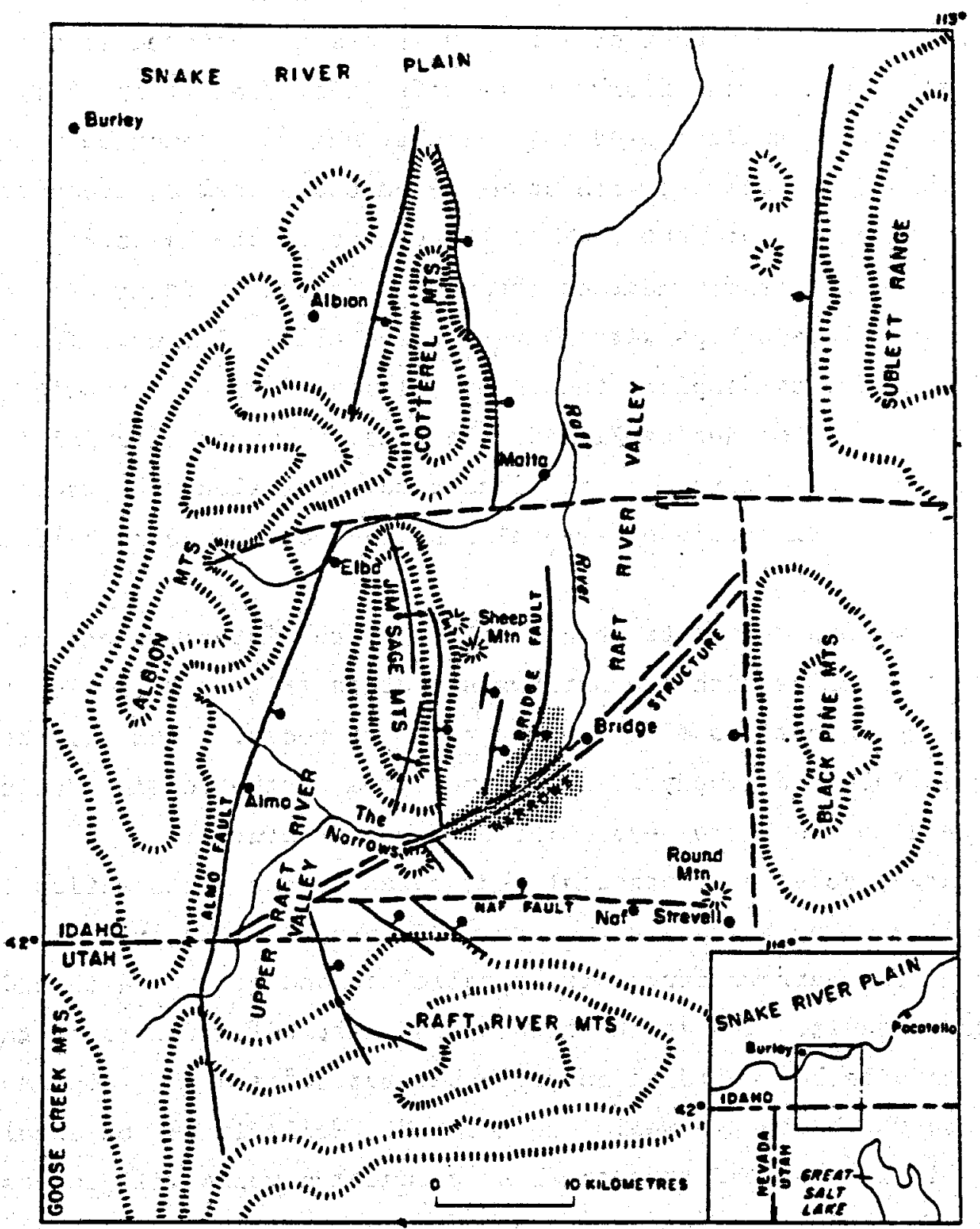

F1g. 2.2. Map of the Raft River Valley reglon, Idaho and Dtah, showing mafor faults (bar and ball on downthrown side; arrows indicate relative direction of movement) and anticlines (Jim Sage Mountains only). The shaded area is the withdrawal area. Source: P. L. Williams et al., Geology and Geophysics of the Southern Raft River Valley Geothermal Area, Idaho, U.S.A., U.S. Geological Survey Open File Report 75-322, Denver, Colo., 1975. 
and $1600 \mathrm{~m}$ ( 4600 and $5200 \mathrm{ft}$ ) in deep geothermal test holes within the basin. The section above the Precambrian consists entirely of Tertiary strata overlain by a thin veneer of Eolocene sediments.?

A relatively thin veneer of Tertiary strata are exposed in the Jim Sage Mountains on the west flank of the Raft River Basin (Fig. 2.1). These strata dip eastward toward the basin at angles varying between $15^{\circ}$ and $30^{\circ}$. This dip, together with down-to-the-basin faults, accounts for the greater depth to basement rock in the center of the basin. 1

Age of the latest movement on the normal faults 18 inferred from cross-cutting relationships with loess-mantled alluvial fans. The north-trending faults displace the older alluvial fans representing cyclic pluvial periods during pleistocene time. Younger alluvial fans conceal the faults. Therefore, the latest movement along the faults is older than middle Pleistocene (several hundred thousand years before the present). ${ }^{1}$

Thermal waters appear to be controlled by the intersections of the north-trending faults with The Narrows structure (Fig. 2.2), which is believed to be a shear zone within the basement rocks. From all the available surface and geophysical evidence, the north-trending faults do not extend to the south beyond The Narrows structure.

The target zone for geothermal test holes is the intersection of the Bridge fault and The Narrows structure. "Step-out" wells are drilled to the north of The Narrows structure, parallel to and on the basinward side of the Bridge fault. The depth at which the test holes intersect the fault (which dips basinward at an angle between $60^{\circ}$ and $70^{\circ}$ ) depends on how far into the basin the wells are located. While it is not absolutely essential, it is expected that the best production wells will intersect open fracture zones adjacent to recently active faults.

The thrust sheets do not appear to be related to geothermal resources of the Raft River Basin. They developed during the Laramide orogeny and there is no longer any active movement along them. No Paleozoic or Mesozolc strata were encountered between the overlying Tertlary and Precambrian rocks at the bottoms of the geothermal holes. The possibility exists, however, that Tertlary strata rest unconformably on Paleozoic 
and Mesozolc strata farther to the east and north in the Raft River Basin. 1,2

\subsubsection{Stratigraphy}

A comprehensive discusston of the stratigraphy is given in the Environmental Report, Raft River Thermal Loop Facility. 3 The following description is taken directly from that report:

The basement rock Is Intruded Precambrian quartz monzonite. This is overlain by a metamorphosed Precambrian series of schists and quartzites of which the Elba quartzite has been defined in deep wells. The Paleozolc sediments found in the southern and eastern borders of the valley were not encountered in the area north of The Narrows. Here the Precambrian metamorphosed serles are unconformably overlain by the tuffaceous siltstones and sands of the Salt Lake Formation. These grade upward into the younger Raft River sediments which contain more unconsolidated sands and gravels which are in turn covered by alluvial material of recent age.

The Salt Lake Formation consists of sedimentary and volcanic rocks having an aggregate exposed thickness of at least 762 m $(2500 \mathrm{ft})$. The general relations (FIg. 2.1) suggest that the formation is composed of three units having maximum thicknesses of about $520 \mathrm{~m}$ (1700 ft) for a lower sedimentary unit (TsI), $150 \mathrm{~m}$ (500 ft) for a central zone of welded tuffs (Tsj), and $\varepsilon \varepsilon$ much as $150 \mathrm{~m}(500 \mathrm{ft})$ for an upper sedimentary unit (Tsu). The massive volcanic rocks of the Cotterell Range occupy the central unit (Tsj). Present usage restricts the name Salt Lake Formation to deposits of Pliocene age.

The Raft Formation consists of lake and stream deposits that accumulated on the eroded surface of the Salt Lake Formation as drainage to the north was progressively blocked by basalt of the Snake River Plain. The formation is well exposed only in the northeastern part of the valley, yet it probably underIles most of the valley to the south, beneath a cover of younger alluvial materials.

Well drllling has disclosed sediments of probable lacustrine origin at many places beneath the floor of the valley, and these are presumed to be in the Raft Formation. In general, subsurface lakebeds at shallow depth beneath the north-central part of the valley floor probably are Raft Formation or younger, whereas those at greater depth and along the east and south flanks of the valley are Indeterminate as to whether they are Raft Formation or a part of the Salt Lake Formation. The percentage of coarse-grained material in the Raft Formation in the main valley increases markedly toward the south. Gravel is much more common toward the south than it is at the north, and the 
sand is coarser grained. Beds of clay are mostly thin, but are abundant. Individual beds thicken or thin within short distances and can only rarely be correlated between wells a short distance apart.

In the northern end of the Raft RIver Valley, basaltic lavas of the Snake River group crop out at land surface. There, and for some distance southward, the basalt interfingers with stringers of the Raft Formatlon, suggesting that a thickening section of basalt progressively dammed the outlet of the ancestral Raft River, leading to the formation of lacustrine conditions in the northern part of the valley and deposition of thick sections of Raft Formation alluvial deposits southward in the valley.

Deposits of mud, silt, sand, and gravel are widespread on the valley floors and scattered on the mountain slopes. Unch of the materlal has been transported for long distances by running water and 15 moderately-to-well sorted and distinctly stratified. Where the alluvium has not moved far, as in alluvial fans along the bases and lower slopes of mountalns, it is less well sorted and 18 poorly stratifled. Windblown deposits ... are widespread; they overlle mich of the basalt of the Snake River Group and other formations in the vicinity of Sublett, Hegler, and the northwestern part of the valley. The deposits reach a thickness of at least $30 \mathrm{~m}$ (100 ft) in depressions on the basalt of the Snake River Group, on leeward slopes of hills and in sheltered basins. Most of the material is silt size; it is buff to brown, highly porous, unstratified and has crude columnar structure. The age probably is late Plelstocene and Holocene.

Geothermal and Irrigation water are produced from widely separated parts of the stratigraphic section. Irrigation water 1s produced at shallow depth from unconsolidated sands and gravels of the Raft Formation and recent alluvium. On the other hand, geothermal water is produced at a depth of between 1100 and $1500 \mathrm{~m}$ (3600 and $4900 \mathrm{ft}$ ) from fault-related fractures in the lower part of the Salt Lake Formation and Precambrian schist of the upper Narrows directly above the Elba Quartzite. Hydraulic connection between these two aquifers is pooor in some locations because there are a number of lacustrine beds that lie between them. Geohydrology is discussed in greater detail in Sect. 2.2.

\subsubsection{Selsmicity}

Algermissen ${ }^{4}$ classifies the region Including the Raft River Valley as a zone 3 earthquake risk ( $F 1 g \cdot 2.3$ ), that 18 , one in which major . 


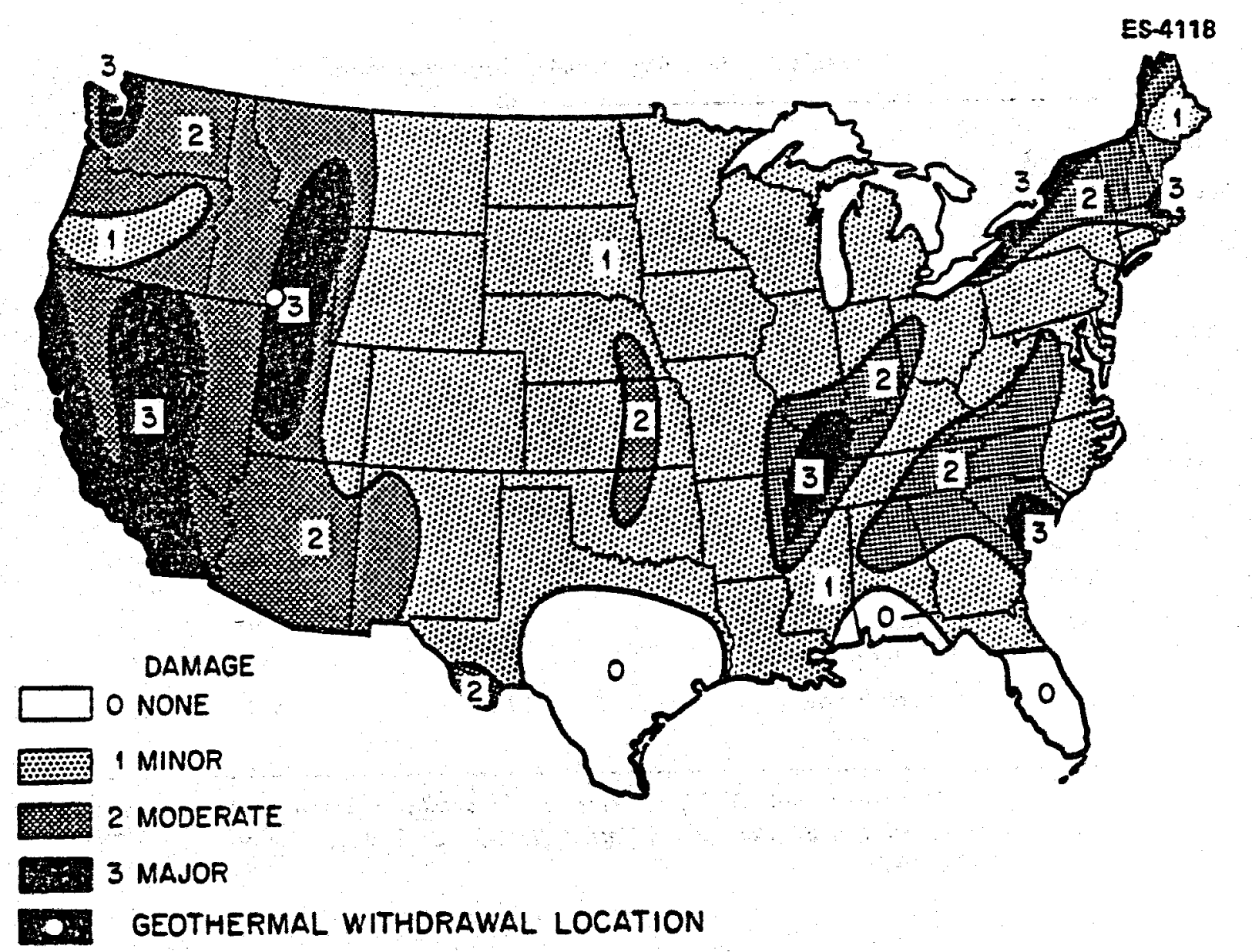

Fig. 2.3. Selsmic rlsk map of the United States. Source: S. T. Algermissen, United States Earthquakes, 0.S. Government Printing Office, 1968.

destructive earthquakes may occur. The most active areas within this reglon, however, are $100 \mathrm{~km}$ ( $60 \mathrm{mlles)}$ or more northeast and east of the Raft River in the vicinity of Yellowstone and the Wasatch Front, respectively, along the Idaho-Wyoming border and Into central Utah. This zone 16 known as the Intermountain Seismic Belt.

According to Algermissen and Perkins, 5 Raft River Iles In sèlomic source zone 30 , immediately adjacent to source zones 26,32 , and 34 . Selsmic source zones 26 and 34 , together with source zones 29 and 33 , comprise the Intermountain Selsmic Belt. Table 2.1 lists the relative 
Table 21. Seismic parameters for source zones

\begin{tabular}{|c|c|c|c|c|}
\hline $\begin{array}{l}\text { Zone } \\
\text { number }\end{array}$ & Location & $\begin{array}{l}\text { Number of modified } \\
\text { Mercalli maximum- } \\
\text { intensity } V \text { earth- } \\
\text { quakes per } 100 \text { years }\end{array}$ & $\begin{array}{l}\text { Maximum } \\
\text { credible } \\
\text { intensity }\end{array}$ & $\begin{array}{l}\text { Maximum } \\
\text { credible } \\
\text { magnitude }\end{array}$ \\
\hline 9 & $\begin{array}{l}\text { Humboldt Depression, } \\
\text { west-central Nevada }\end{array}$ & 125 & $x i$ & 7.9 \\
\hline 17 & Imperial Valley, Califomia & 223 & $x 1$ & 7.9 \\
\hline 26 & Idaho-Wyoming border & 137 & VI & 4.9 \\
\hline 29 & Yellowstone & 90.4 & $x$ & 7.3 \\
\hline 30 & $\begin{array}{l}\text { Southwest Idaho, } \\
\text { including Raft River }\end{array}$ & 10.5 & VII & 5.5 \\
\hline 32 & Nevada-Utah border & 17.0 & VI & 4.9 \\
\hline 33 & $\begin{array}{l}\text { Wasatch Front of } \\
\text { north central Utah }\end{array}$ & 127 & ix & 6.7 \\
\hline 34 & $\begin{array}{c}\text { Wasatch Front, } \\
\text { border zone }\end{array}$ & 71.0 & VII & 5.5 \\
\hline
\end{tabular}

'S. T. Algermissen and D. M. Perkins, A Prababilistic Estimate of Maximum Acceleration in Rock in the Contiguous United States, U.S. Geological Survey; Open File Report 76-416, 1976.

frequencies of modified Mercalli intensity $\mathbf{V}$ earthquakes, maximum credible Intensities, and maximum credible magnitudes that are 1ikely to occur in these source zones. Source zone 17 (Imperial Valley, California) and 9 (Humboldt Depression, Nevada) are Included for comparison. 5

These data show that the Raft River region is seismically inactive relative to surrounding regions. The maximum credible modified Mercall1 intensity is VII; an earthquake of this intensity is capable of causing slight to moderate damage to ordinary well-built structures and considerable damage to poorly built structures. Searches of the Earthaqake Bistory of the United States ${ }^{6}$ and National Oceanlc and Atmospheric Administration data files indicate no historical records of earthquakes In Cassia County, Idaho. Eowever, Slemons, Jones, and Gimlett ${ }^{7}$ Ist two events of the $1930 \mathrm{~s}$ with magnitudes of 5.1 and 5.4 (intensity between VI and VII). 3 
It is difficult to assess whether earthquakes whose epicenters ile outside the Raft River Valley are capable of producing intensity VII destruction with the valley. Maximum credible earthquakes in the Humboldt Depression, the Yellowstone reg1on, or the Wasatch Front are likely to be felt in the Raft RIver Valley; but they probably w11 not cause significant damage. For example, the Hebgen Lake earthquake (Yellowstone region) of 1959 had an intensity of $X$ in the epicentral region but only IV at Raft RIver, strong enough to be felt by people who are indoors. 8

Microselsmic studles were conducted in 1974 to characterlze the microselsmicity in the erea of geothermal development. Resu'ts indicate that the frequency of microseismic activity in the Raft River Valley is an order of magnitude lower than that of the Geysers Geothermal Field of California. 3

\section{$2.1 .3 \underline{50118}$}

The soils in the Raft River Valley are prfmarily young alluvial so11s. Solls along the floodplain are mainly ollty or sandy loams with some clay. Soils of the pledmont slopes are almost entitely loam. A few locations contain s1gnificant amounts of gravel. 3

The solls along the river are calcareous, and all solls (with one exception) have $a$ moderate to strong lime accumulation at depths of 10 to $76 \mathrm{~cm}$ (4 to 30 1n.). The alkalinity and salinity of these solls range from moderate to very high. Fermeabilitles range from moderate to Iow, except for gravelly solls whose average permeability is rather high. Runoff is slow and erosion hazard is slight. Fine silty loams have a moderate wind eroston hazard. 3

Land capability clessifications range from unsultable for irrigation to a high potential for 1rrigated cropland. Without Irrigation, none of the solls is buitable for cropland. Figure 2.4 is a so1ls map of the region. Table 2.2 gives a general land use classification. Soll unlts $104,121,122,245$, and 490 are important egricultural so11s that are within or close to the Raft River Pllot Plant facllities. Detailed descriptions of these soll units are glven In Table 2.3. 
ES-4127

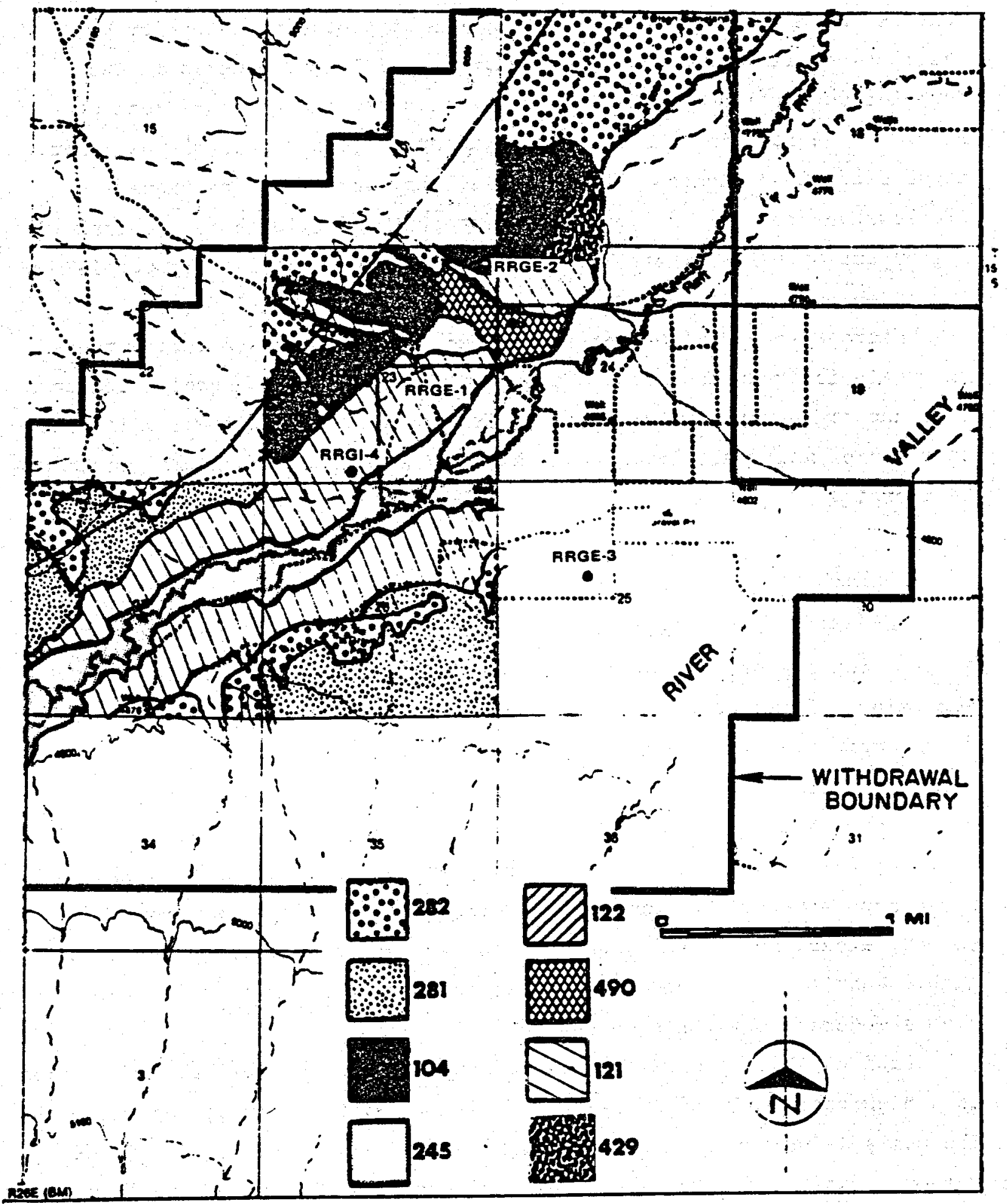

Fig. 2.4. Solls map for the Raft River thermal loop facility. Source: Idaho Natlonal Engineering Laboratory, Environmental Report, Raft River Thermal Loop Facility, TREE-1144, 1977. 
Tablo 2.2. Land une classifieation"

\begin{tabular}{|c|c|c|c|c|}
\hline & Limitations or hazards & Soll suitability & Applicablitity of agriculiure & Impact of use \\
\hline Class II & $\begin{array}{l}\text { Few; simple care and conservation } \\
\text { practices are required }\end{array}$ & $\begin{array}{l}\text { Wide range of use, with limited erosion } \\
\text { control, water control or disposal, } \\
\text { fertility level managoment, or surface } \\
\text { disturbence necessary to the mainte: } \\
\text { nance or enhancement of the resource }\end{array}$ & $\begin{array}{l}\text { Intensive row crop agriculture is } \\
\text { applicable }\end{array}$ & High-impact use is applicable \\
\hline Class IV & $\begin{array}{l}\text { Strict limitations and hazard } \\
\text { consideration }\end{array}$ & Renge, woodiand, wildife, open space & $\begin{array}{l}\text { Soils are marginal for agricultural } \\
\text { purposes; best sulted for hay and } \\
\text { pasture, if cultivated }\end{array}$ & $\begin{array}{l}\text { Inherent soll characteristics prectude } \\
\text { most high-impact use }\end{array}$ \\
\hline Class V & $\begin{array}{l}\text { Little or no erosion hazerd. } \\
\text { Limitations such as high water } \\
\text { tables prevent cultural develop- } \\
\text { ment }\end{array}$ & Pasture, moodiand, wildife, open spece & $\begin{array}{l}\text { Conversion to production of } \\
\text { cultivated crops possible where } \\
\text { and if proper drainage is installed }\end{array}$ & . \\
\hline Cless VI & $\begin{array}{l}\text { Severe llmitations or hazards to } \\
\text { use: shallow, droughty soils: } \\
\text { short, abrupt slopes; actuerse } \\
\text { climate regime; severe wind and } \\
\text { water erosion hozard in certain } \\
\text { instances these limitations may } \\
\text { be overcome through extensive } \\
\text { ond detalled cuitursl practice, } \\
\text { but this is usually not feasible }\end{array}$ & $\begin{array}{l}\text { Ronge, woorliand, watershed, wildilfe, } \\
\text { open spoce, aesthetic use }\end{array}$ & Exctionded & \\
\hline $\begin{array}{c}\text { Class VII } \\
\vdots\end{array}$ & $\begin{array}{l}\text { Extreme limitations or hazards to } \\
\text { use: shallow soil mantle, steep } \\
\text { stope gradients, highly erosive } \\
\text { solis }\end{array}$ & $\begin{array}{l}\text { Aonge, woodlend, watershied, wildilfe, } \\
\text { open space }\end{array}$ & Excluded & $\begin{array}{l}\text { Inherent soll characteristics preclude } \\
\text { use hoving Intense impact upon the } \\
\text { resource }\end{array}$ \\
\hline
\end{tabular}

"Idaho National Engineering Laboratory, Environmental Aeport, Roft Alver Thermal Loop Facility, TAEE-1144, 1977. 
Tatlo 2.3. Cheractorionten of the rotile

\begin{tabular}{|c|c|c|c|c|c|c|c|}
\hline Cherectoristices & & & & Solls & & & \\
\hline Soll unit: & 104 & 104 & $121-122$ & 245 & $201-282$ & 429 & 180 \\
\hline Soll nem & Avoum Loom & Hiko Paok & Brom Bit Lown & Genole SIIt Loem, Solime & Decto Losm, Salima-Alkell & $\begin{array}{l}\text { Pocatello Site Loom. } \\
\text { Seline }\end{array}$ & Smoetzer Sith Loom \\
\hline $\begin{array}{l}\text { Demeription } \\
\text { Surfeco layer }\end{array}$ & Loem and sllt toem & Losm & Silt loem & $\begin{array}{l}\text { Silt loem, very line sendy } \\
\text { lown }\end{array}$ & Loem (nurtece and sutsoin) & sile lown & silt loom \\
\hline depth, cm(in.) & 15(6) & $10(4)$ & $10(1)$ & $23(13)$ & $\begin{array}{l}\text { Surfuan: } 13 \text { (5); } \\
\text { nubsoll: } 30 \text { (14) }\end{array}$ & $162(100)$ & $33(13)$ \\
\hline Substrotum & $\begin{array}{l}\text { Growlly semoy loom and } \\
\text { sond }\end{array}$ & $\begin{array}{l}\text { Vory wrwelly loom, very } \\
\text { erewelly sand } \\
109 \text { (43) }\end{array}$ & & $\begin{array}{l}\text { Silcy ctor lown, coy } \\
\text { lown, very fine iendy } \\
\text { lowm } \\
\text { les }(72)\end{array}$ & 1521609 & & $\begin{array}{l}\text { Silt loom, sllty cley loom. } \\
\text { and loam ower very } \\
\text { movelly loany sand } \\
137 \text { (54) }\end{array}$ \\
\hline $\begin{array}{l}\text { Underlying loyert } \\
\text { depth,cm (in.) }\end{array}$ & $\begin{array}{l}\text { Grevelly lown, very } \\
\text { erewelly semdy loem, } \\
\text { send, growelly send } \\
142 \text { (66) }\end{array}$ & Sencty loam & $\begin{array}{l}\text { Silt lowm or sility clor } \\
\text { lown } \\
1621001\end{array}$ & & 1021047 & & \\
\hline Stopo, $x$ & $4-12$ & $4-12$ & $\begin{array}{l}0-2 \text { (Unit 121) } \\
2-4 \text { (Unit 122) }\end{array}$ & & $\begin{array}{l}0-1 \text { (Unit 2al) } \\
4-12 \text { (Unit 2a2) }\end{array}$ & $0-4$ & $0-2$ \\
\hline Dralnem & Exconively dralned & Woll drained & Moderotely woll drelned & Well dreined & Well drolined & Wels drained & Woll atained \\
\hline Pormoability & Modorotely ropid & Moderoisty reppld & Maderately stow & Modornte & Moderense & Modornte & Moderntely slow \\
\hline Zom of lime sccumulotion, cm (in.) & $16-64(8-25)$ & $\begin{array}{l}\text { Strom aceumutetion: } \\
10-71(4-28)\end{array}$ & $10-70(4-30)$ & $\begin{array}{l}\text { Calcerroous; depth not } \\
\text { owallidele }\end{array}$ & $\begin{array}{l}\text { Stron peavmulention: 38-69 } \\
(16-27)\end{array}$ & $\begin{array}{l}\text { Calcorrous; depth not } \\
\text { wniloblo }\end{array}$ & Below 51 (20) \\
\hline Alketinity & Moderate to strong & Modorite to strong & Very strong & Modiernete & Moderinte to strong & Moderate to strom & \\
\hline Solinity & Strong & $\begin{array}{l}\text { Strom bolow depth of } \\
36 \mathrm{~cm}(14 \mathrm{in} .)\end{array}$ & & Moderete to very itrong & Strong & Strong & \\
\hline Effective rootling depth, cm (im.) & $152(60)$ or more & 1521601 or more & $10-162(4-60)$ & $152(60)$ or more & 162 (60) or more & 162 (180) or more & $102-152(40-60)$ \\
\hline Avaifeble water cappecity, cm (in.) & $6.1-8.1(2.4-3.6)$ & $10.7-13.7(19.2-8.9)$ & $6.4-10.2(2.5-9.0)$ & $23-30(9-12)$ & $17.8-22.8(7.0-8.0)$ & $8.4-12.7(2.8-8.0)$ & $21.6-30.5(8.5-12)$ \\
\hline surtace runoft & Motium & Modium & Slow & Slow & Slow & $\begin{array}{l}\text { Stow to medium } \\
\text { (Iirigoted): Alow (non- } \\
\text { Irrigoted) }\end{array}$ & Stom or very slow \\
\hline Erotion hazerd & Modorato & Moderote & Silght & slight & Sliost & $\begin{array}{l}\text { Stight to moderme } \\
\text { (irrigened): ellight (non. } \\
\text { (rrigatod) }\end{array}$ & Stight \\
\hline Soil blowing hazurd & slowt & stiont. & Moderete & stight & Moderinte & Modhrote" & Slight \\
\hline Lnd un copsbillite" & Am vi or vil in & Cion Vi or VIIIn & 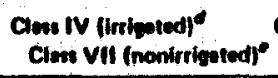 & $\begin{array}{l}\text { Clms II (irripotodl } \\
\text { Clom VI inonlerigated) }\end{array}$ & 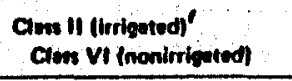 & $\begin{array}{l}\text { Clom II Iirrigatedf' } \\
\text { Cless VI (nonitrigoted) }\end{array}$ & Com II' $\mid \eta$ \\
\hline
\end{tabular}

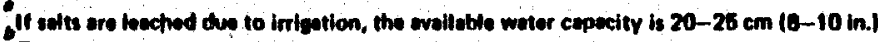

Thera is, howover, a chennetod river through this unit that heod euts into this soll.

for a definition of lind use clemeses see Toble 2.2.

Soll limitied by droughtiness.

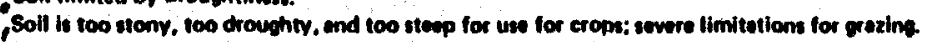

Soll moderately limited by droughtiness.

Colluvies roll limited by stones on the surfecen.

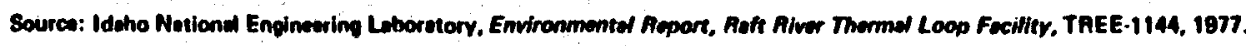




\subsubsection{Geothermal resources}

According to Renner, White, and Williams the Raft River thermal area is the fourth largest in Idaho, after the Bruneau-Grandview, He1ser, and Crane Creek areas. It has an estimated $20 \mathrm{~km}^{2}(7.7 \mathrm{sq}$ m1le) surface area, $1.5 \mathrm{~km}(0.9 \mathrm{mlle})$ thickness, $30 \mathrm{~km}^{3}(7.2 \mathrm{cu}$ mile) volume, and $2.3 \times 10^{18}$ calorie heat content. 9

The above estimates are preliminary. The actual extent of the geothermal reservoir remains undefined. Warm water flows from several Irrigetion wells in or near the Raft River Valley - for example, wells near Albion and Almo. Warm water was also encountered during the drillIng of a nonproductive o1l well near Malta, Idaho. There is a warm water seep at the east end of The Narrows. Near the northwest corner of Section 23, TI5S, R26E hydrotherma11y altered alluvium marks the location of a former hot spring. An Irrigation well drilled near the hot spring in the $1920 \mathrm{~s}$ to $126 \mathrm{~m}$ (414 ft) ylelds 38 liters $/ \mathrm{sec}$ ( $60 \mathrm{gpm}$ ) water at $93^{\circ} \mathrm{C}\left(200^{\circ} \mathrm{F}\right)$. Another shallow well in the southeast corner of Section 23 yields $90^{\circ} \mathrm{C}\left(194^{\circ} \mathrm{F}\right)$ water at about the same production rate. ${ }^{3}$

By the end of 1976, three geothermal test holes had been drilled to basement for the development of the Raft River P1lot Plant facility. Characteristics of these wells are presented in Table 2.4. Preliminary results suggest reservoir temperatures of approximately $148^{\circ} \mathrm{C}\left(298^{\circ} \mathrm{F}\right)$ and wellhead pressures between 9.5 and 11.9 atm (140 and $175 \mathrm{ps1}$ ) at depths between 1400 and $1600 \mathrm{~m}$ (4600 to $5300 \mathrm{ft}$ ). Flow rates range between 25 and 32 IIters/sec ( 400 and $500 \mathrm{gpm}$ ) under arteslan drive. Flow rates can be improved by means of a pump to between 69 and 9511 ters/sec (1100 to $1500 \mathrm{gpm}$ ) with between 150 and $300 \mathrm{~m}(500$ to $1000 \mathrm{ft}$ ) predicted drawdown over ten years of continuous operation. While the water is slightly hotter in RRGE-3, Its salinity is three times that of the other two wells. Also, Its sustained pumping rate is estimated to be only onethird to one-half that of the other wells. These facts suggest that while reservolr temperature is expected to be relatively unfform, salinities and production rates may vary by a factor of 2 to 3. Some wells may require a form of reservolr stimulation (such as hydrofracturing) 
Table 2.4. Characteriatics of the wolls"

\begin{tabular}{|c|c|c|c|}
\hline & \multicolumn{3}{|c|}{ Well } \\
\hline$\because \ldots \quad \therefore$ & RRGE No. 1 & RRGE No. 2 & RRGE NO. 3 \\
\hline $\begin{array}{l}\text { Completion date } \\
\text { Deoth } f(m)\end{array}$ & $\begin{array}{l}\text { March } 1975 \\
5000(1500)\end{array}$ & $\begin{array}{l}\text { June } 1975 \\
6500(2000)\end{array}$ & $\begin{array}{l}\text { June } 1976 \\
5900(1800)\end{array}$ \\
\hline Production interval, $\mathrm{ft}(\mathrm{m})$ & $3700-4700(1100-1400)$ & $4200-4700(1300-1400)$ & $5000-5800(1500-1800)^{b}$ \\
\hline $\begin{array}{l}\text { Chemical species, } \\
\text { mean concentration } \\
\text { in mg/liter (ppm) }\end{array}$ & & & - \\
\hline $\mathrm{Cl}^{-}$ & 776 & 708 & 2170 \\
\hline $\mathbf{F I}^{-}$ & 6.32 & 8.25 & 4.55 \\
\hline Total $\mathrm{NH}_{3}$ & 1.56 & 0.60 & $\cdots$ \\
\hline $\mathrm{SO}_{4}{ }^{2-}$ & 60.2 & 54.1 & 53.3 \\
\hline Total dissolved solids & 1560 & 1267 & 4130 \\
\hline Artesian pressure, psig cold & 50 & 60 & 40 \\
\hline Artesian pressure, psig hot & 175 & 165 & 140 \\
\hline Reservoir temperature, ${ }^{\circ} \mathrm{F}\left({ }^{\circ} \mathrm{C}\right)$ & $297(147)$ & $298(148)$ & $301(149)$ \\
\hline Flow experience & $\begin{array}{l}400 \mathrm{gpm} \text { (25 liters/sec) for } \\
\text { many days with artesian } \\
\text { pressure only. } 870 \mathrm{gpm} \\
\text { (55 liters/sec) for four } \\
\text { days with a pump. draw- } \\
\text { ing down } 375 \mathrm{ft} \text { (114 m) } \\
\text { below ground level. }\end{array}$ & $\begin{array}{l}500 \mathrm{gpm} \text { (30 liters/sed) for } \\
\text { several days with artesian } \\
\text { pressure only. }\end{array}$ & $\begin{array}{l}400 \mathrm{gpm} \text { (25 liters/sec) for } \\
\text { one day under artesian } \\
\text { pressure }\left(291^{\circ} \mathrm{F}, 144^{\circ} \mathrm{C} \text {. }\right. \\
\text { at surface). }\end{array}$ \\
\hline $\begin{array}{l}\text { Predicted flow after ten years } \\
\text { of operation }\end{array}$ & $\begin{array}{l}1100 \mathrm{gpm} \text { (69 liters/sec) } \\
\text { with } 900 \mathrm{ft}(300 \mathrm{~m}) \\
\text { drawdown below ground } \\
\text { level. }\end{array}$ & $\begin{array}{l}1500 \mathrm{gpm} \text { (95 liters/sec) } \\
\text { with } 900 \mathrm{ft}(300 \mathrm{~m}) \\
\text { drawdown below ground } \\
\text { level. }\end{array}$ & $\begin{array}{l}500 \mathrm{gpm}(30 \text { liters } / \mathrm{sec}) \\
\text { with } 1000 \mathrm{ft}(300 \mathrm{~m}) \\
\text { drawdown below ground } \\
\text { level. }\end{array}$ \\
\hline
\end{tabular}

-Idaho National Engineering Laboratory, Idaho Geothermal Development Projects Annual Report for 1976, Idaho Falls, Idaho.

Extrapolated.

or directional drilling (as in the case of RRGE-3) 10 to stimulate production.

The geothermal resource has an apparently abundant oupply of recharge water. Evidently meteorlc water percolates to great depths, where it is heated and then migrates horizontally and upward along shear zones such as The Narrows structure and the Bridge fault. The source of the recharge is unknown, but it way be much larger than local areas to the south, east, and west. It has been speculated that the vast recharge area of the Snake River Plain provides water from the north through the Intertongueing of the Raft Formation with Snake River flood basalt. 3 
Characteristics of the groundwater suggest that the geothermal resource is liquid-. (rather than vapor-) dominated. Chloride is the dominant dissolved constituent as opposed to sulfate, and the reservoir temperature is no higher than $150^{\circ} \mathrm{C}\left(300^{\circ} \mathrm{F}\right) .^{3}$

\subsection{HYDROLOGY AND WATER QUALITY}

\subsubsection{Surface water}

The Raft River is the most important surface water feature in the project area. It is a tributary to the Snake River, which in turn feeds the Columbia River. The Raft River originates in northern Utah, is fed by tributarles such as Cassia, Edwards, and Almo Creeks, and joins the Snake Rlver just upstream from the Lake Walcott impoundment. The Raft River Basin also Includes many small channels with occasional or seasonal flow, draining the surrounding mountain ranges. Figure 1.1 shows the major surface waters in the Raft RIver Basin, and FIg. 2.5 shows the drainage channels in the project area. Although there is a remote possibility that the heat exchangers might be flooded, the main plant is located on a terrace deposit at 5 m (15 ft) higher elevation, well above the flood area (FIg. 2.5). The basin extends over an area of approximately $3910 \mathrm{~km}^{2}$ ( $1510 \mathrm{sq}$ mlles), of which about $80 \%$ is located in Idaho.

Water depletfons within the Raft River Basin consist of (1) natural evapotranspiration; (2) replacement of shallow groundwater lost by (1): (3) 1rrigation; (4) recharge of groundwater lost as underflow from the Raft River Basin to groundwater along the Snake River; and (5) surface flow of the Raft River to the Snake River. It has been estimated that of the annual precipitation to the basin of $1.6 \times 10^{9} \mathrm{~m}^{3}\left(1.28 \times 10^{6}\right.$ acre-ft), evapotranspiration would deplete about $92 \%$ of the total. of the remaining $8 \%$, the Raft River Basin in its natural or undeveloped state would lose about $6.5 \%$ as subsurface outflow and about $1.3 \%$ as surface (Raft RIver) outflow. 11

Human development of the valley resulted at first in diversion of stream flow, and then in the heavy pumping of groundwater (Sect. 2.7) to satisfy agricultural and domestic needs. Human effects on groundwater 


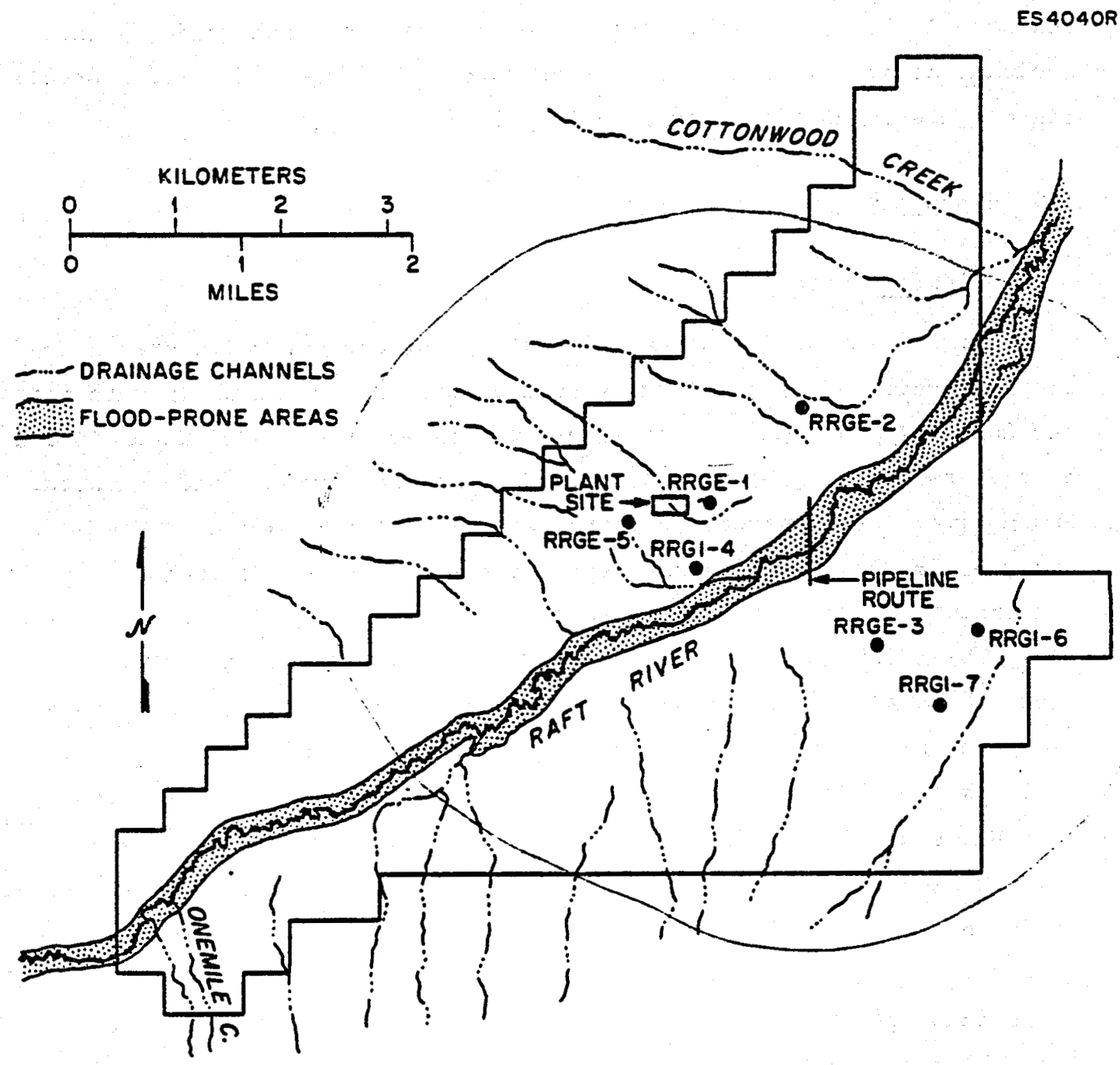

F1g. 2.5. Drainage channels and flood-prone zone in the project area. Source: Modifled from Idaho National Engineering Iaboratory, Enviromental Report, Raft River Thermal Loop Facility, TREE-1144, 1977.

resources are discussed elsewhere (Sect. 2.2.2). The Raft River, which at one time flowed perennially over its entire length, now has reduced flow, and a considerable portion of lts length is dry during the sumer 
as a result of diversions of the streamflow and increased percolation to groundwater. The discharge of the Raft River near Yale in 1910 has been estimated at 2 to $2.2 \times 10^{7} \mathrm{~m}^{3} /$ year $\left(1.6\right.$ to $1.8 \times 10^{4}$ acre-ft/year); by 1968 the discharge had declined by about $90 \%$, to $2.3 \times 10^{6} \mathrm{~m}^{3} /$ year $\left(1.9 \times 10^{3}\right.$ acre-ft/year). 11 As a result of increased water consumption, the Raft River chennel in the sumer is dry from the Bridge-Malta area to near Yale (Fig. 1.1); at which point drainage from groundwater and Irrigation enters the channel and flow resumes.

The flow of the Raft River in the project area varies on a seasonal basis, typically with a lerge peak in late spring, a smaller peak in January, and low flows throughout sumer and autum. As measured near the southwestern boundary of the project ares, mean monthly flows from October 1969 to June 1971 ranged from $0.22 \mathrm{~m}^{3} / \mathrm{sec}(7.71$ cf6) to 4.08 $\mathrm{m}^{3} / \mathrm{sec}$ (144 cfs). Minimum and meximum de1ly averages recorded at that station during the same period were $0.16 \mathrm{~m}^{3} / \mathrm{sec}(5.7 \mathrm{cfs})$ and $29 \mathrm{~m}^{3} / \mathrm{sec}$ (1020 cfs). Instantaneous discharges ranged from $0.02 \mathrm{~m}^{3} / \mathrm{sec}(0.8 \mathrm{cfs})$ to $58 \mathrm{~m}^{3} / \mathrm{sec}(2060 \mathrm{cfs})$ from 1946 to 1971 . The mean annusl total discharge at the station during the period 1969-1970 was $1.612 \times 10^{7} \mathrm{~m}^{3}$ $\left(1.305 \times 10^{4}\right.$ acre-ft). 12

Almo Creek discharges into the Raft River, except in late sumer. Surface runoff from the Raft River Mountains and from the Black Pine and Sublett ranges enters the Raft River only as a result of heavy rainstorms.

Table 2.5 presents chemlcal and bacterlological analyses of water samples from the Raft River taken in the project area from 1975 to 1977. DrInking and Irrigation water standards are given for comparison. Levels of cobalt, chromium, emonle, selentum, total dissolved solids (IDS), and collform bacterla which exceeded these standards have been reported. Mineralization typically increases during the growing season from spring to autumn because of the return of 1rrigation runoff, enriched in nutrients and pesticides, to the low-flowing river.

The suspended sediment yleld of the Raft River has been estimated at 48 to $95 \mathrm{~m}^{3} \mathrm{~km}^{-2}$ year $^{-1}(0.1$ to 0.2 acre-ft $\mathrm{sq} \mathrm{mile}-1$ year). So1l erosion along the stream banks contributes to the river's suspended solids load in the project area. 
Table 2.5. Selected water quality parameters for the Raft River in the project area, 1975-1977. Drinking and irrigation water standards are given for comparison.

[All units are mg/liter (ppm), except for coliform.]

\begin{tabular}{|c|c|c|c|}
\hline Component & $\begin{array}{l}\text { Reported concentration } \\
\text { in Raft River water }\end{array}$ & $\begin{array}{l}\text { Drinking water } \\
\text { standard }\end{array}$ & $\begin{array}{l}\text { Irrigation water } \\
\text { standard }\end{array}$ \\
\hline As & 0.006 & $0.05^{c .0}$ & 0.10 \\
\hline $\mathbf{B}$ & $0.07-0.12$ & $1.0^{6}$ & 0.75 \\
\hline $\mathrm{Ba}$ & 0.016 & $1.06,0$ & \\
\hline $\mathrm{Br}^{-}$ & $0.38-<1.5$ & & \\
\hline $\mathrm{Cl}^{-}$ & $63-204$ & $250^{d, f}$ & \\
\hline Co & 2.8 & & 0.05 \\
\hline $\begin{array}{l}\text { Coliform, total (per } \\
100 \mathrm{ml} \text { ) }\end{array}$ & $20-2780$ & $1-4^{c, d, \theta}$ & \\
\hline$\frac{\mathbf{C r}}{\mathbf{F}}$ & $\begin{array}{r}0.0006 \\
0.44-0.78\end{array}$ & $\begin{array}{l}0.05^{c, d} \\
2.0^{c, d, h}\end{array}$ & $\begin{array}{l}0.10 \\
1.0\end{array}$ \\
\hline $\mathrm{Hg}$ & $0.00003-0.0007$ & $0.002^{c . d}$ & \\
\hline$i^{2}$ & 0.036 & & \\
\hline $\mathrm{Li}$ & 0.04 & & 2.5 \\
\hline $\begin{array}{l}\mathrm{NH}_{3} \text {, total } \\
\left.\mathrm{NO}_{3}-\text { (as } \mathrm{N}\right)\end{array}$ & $\begin{array}{l}0.1 \\
0.2-3.8\end{array}$ & $\begin{array}{c}0.5^{i} \\
10^{6.0}\end{array}$ & \\
\hline $\begin{array}{l}\text { P, total } \\
\text { PO }^{3-}\end{array}$ & $\begin{array}{c}0.038 \\
0.06-0.17\end{array}$ & & \\
\hline & 0.0003 & $0.01^{c, d}$ & 0.020 \\
\hline $\mathrm{SO}_{4}{ }^{2-}$ & $29-78$ & $250^{d, f}$ & \\
\hline TDS & $376-758$ & $500^{d . f}$ & \\
\hline $\mathbf{Z n}$ & Not detected & $5.0^{d, f}$ & 2.0 \\
\hline
\end{tabular}

'Idaho National Engineering Laboratory, Enviranmental Report, Raft River Thermal Loop Facility, TREE-1144, 1977; and S. Spencer (Idaho National Engineering Laboratory). personal communication.

${ }^{b}$ Committee on Water Quality Criteria, Water Quality Criteria 1972, EPA-R3. 73-033-March 1973, Environmental Studies Board. Academy of Sciences and National Academy of Engineering, 1972.

C"National interim primary drinking water regulations," Fed. Regist. 40(248) (1975).

dRegulations for Public Drinking Water Systems (proposed), Department of Health and Welfare, State of Idaho, 1977.

-Water Quality Criteria: Report of the National Technical Advisory Committee to the Secretary of the Interior, Federal Water Pollution Control Administration, 1968.

The Public Health Service Drinking Water Standards, PHS Publication 956, U.S. Public Health Service, rev. 1962.

$\checkmark$ Depending on the number of samples taken.

h Based on an estimated average daily maximum air temperature of $17^{\circ} \mathrm{C}\left(62.5^{\circ} \mathrm{F}\right)$.

'European Standards for Drinking Water, World Health Organization, Geneva, Switzerland, 1961. 
The Raft River has been designated a Class A waterway by the State of Idaho, from the upper reaches to the confluence with the Snake River. Uses of the Raft River to be protected Include domestic water supply, industriel water supply, Irrigation, livestock watering, salmonid fish spawning and reering, other fishing and equatic life, hunting and widI1fe, water skilng and swiming, pleasure bosting, and sesthetics. 14

There is no annuel spring flooding along the Raft River. Nevertheless, F1g. 2.5 shows the areas along the Raft River characterized by the USGS as Elood-prone. 3

\subsubsection{Groundwater}

Except where noted, this discussion of groundwater resources in the project area and surrounding basin has been adapted from the comprehensive study by Walker et al. Il

Groundwater in the Raft River Valley comprises the most important water resource, because of the large volume in storage and because of 1 ts heavy use for Irrigation (Sect. 2.7). Unconfined groundwater occurs primarily in the Salt Lake Formation (bandy sediments with some volcanic rock), the Raft Formation (sand, gravel, leke sediment6, silt, and clay), and the more recent alluvial deposits. (See sect. 2.1 .1 for a discussion of the geological formations underlying the valley.) Artesian conditions prevail at only a few locations along the marglns of the lowlands. (See also sect. 2.1.4 for a discussion of the BIM and Crank wells.) The thickness of the water-bearing units ranges from near 0 in at the eastern boundary of the valley to approximately $450 \mathrm{~m}$ (1500 ft) near the northwestern corner of the valley. In the project area, the thickness of the waterbearing deposits is about 200 to $250 \mathrm{~m}$ (700 to $800 \mathrm{ft}$ ). The depth of the water table below the surface in the project area varies from near $0 \mathrm{~m}$ In the imediate vicinity of the Raft River channel to $30 \mathrm{~m}$ (100 ft) or more further away from the river. 3 The mean depth of wells in Township 15S, Range 26E, where most of the project area 1s located, was $100 \mathrm{~m}$ (325 ft), with individual wells ranging in depth from 47 to $165 \mathrm{~m}$ (153 to $540 \mathrm{ft}$ ), as reported in 1963.15 
The role played by groundwater in the hydrologic budget of the Raft River area 15 discussed in sect. 2.2.1. It has been estimated that the amount of groundwater in storage in the Raft River Valley in the uppermost $60 \mathrm{~m}$ (200 ft) of water-bearing deposits was $1.1 \times 10^{10} \mathrm{~m}^{3}\left(9 \times 10^{6}\right.$ acre-ft) in 1966. It is this groundwater in storage which has been most affected by the heavy consumptive water use for Irrigation. Beginning around 1950, pumping of groundwater increased from less than $1.2 \times 10^{7} \mathrm{~m}^{3}$ $\left(1 \times 10^{4}\right.$ acre-ft) annually to an estimated $2.9 \times 10^{8} \mathrm{~m}^{3}\left(2.35 \times 10^{5}\right.$ acre-ft) In 1966. Although surface outflow via the Raft River has been greatly reduced by the use of water in the valley (Sect. 2.2.1), the much larger subsurface outflow has not been appreciably affected. Based on the water yield (the amount of water potentially avallable for exploitation), outflows, and consumptive uses, it has been estimated that a considerable amount of water use in the valley (up to $1.3 \times 10^{8} \mathrm{~m}^{3}$ or $1.03 \times 10^{5}$ acre-ft in 1966) has been at the expense of groundwater in storage. The result of this consumptive use of stored groundwater bas been a significant decline in the water table over an area of approximately $610 \mathrm{~km}^{2}$ (235 sq miles), and a dewatering of more than $2.5 \times 10^{\circ} \mathrm{m}^{3}\left(2 \times 10^{6}\right.$ acre-ft) of water-bearing material from 1952 to 1966 . Rates of decline of water levels in wells of up to $2 \mathrm{~m}(6 \mathrm{ft})$ per year have been measured. Groundwater recharge is considerable along the bottom lands of the Raft River and Cassia Creek. However, it 18 minimal at greater distances from the streams and also further downstream where the reduced flow of the streams (Sect. 2.2.1) hes affected this source of recharge.

It has been observed that the water avallable in the valley is Insufficlent for the arount of irrigated land. 16 Because of this problem, the valley was declared a critical groundwater area in 1963 and closed to further water approprlations (Sect. 2.7).

Water quality of groundwater in the Raft RIver Valley, as elsewhere in the basin, varies markedly from well to well, as a function of hydrolog1c movement, local 1rrigation, and well depth. Table 2.6 shows selected water quality parameters for Irrigation wells in the vicinity of the Raft River Geothermal Exploration (RRGE) deep wells, as well as upstream and downstream from the geothermal wells. Irrigation water 
Table 2.6. Selected water quality parameters for groundwater wells in the vicinity of, upstream from, and downstraam from the RRGE geothermal wells in the project aree, 1975-1977. Irrigation water standards are given for comparison. [All units are $\mathrm{mg} / \mathrm{itter}$ (ppm), except for temperature.]

\begin{tabular}{|c|c|c|c|c|c|}
\hline \multirow[b]{2}{*}{ Component } & \multicolumn{4}{|c|}{ Measured concentrations" } & \multirow[b]{2}{*}{$\begin{array}{l}\text { Irrigation } \\
\text { water } \\
\text { standard }\end{array}$} \\
\hline & $\begin{array}{l}\text { Upstream from } \\
\text { RRGE wells }\end{array}$ & $\begin{array}{l}\text { In vicinity } \\
\text { of RRGE } \\
\text { wellse }\end{array}$ & $\begin{array}{c}\text { Downstream } \\
\text { from RRGE } \\
\text { wells }\end{array}$ & $\begin{array}{c}\text { All } \\
\text { wellse }\end{array}$ & \\
\hline As & 0.0 & 0.0 & 0.0 & & 0.10 \\
\hline $\mathbf{B}$ & 0.09 & 0.15 & 0.08 & & 0.75 \\
\hline $\mathrm{Ba}$ & & 0.025 & & & \\
\hline $\mathrm{Cl}^{-}$ & 212.0 & 726.0 & 419.0 & & \\
\hline Co & & & & 0.02 & 0.05 \\
\hline $\mathrm{Cr}$ & & & & 0.6 & 0.10 \\
\hline $\mathbf{F}^{-}$ & 0.31 & 3.2 & 0.0 & & 1.0 \\
\hline $\mathrm{Fe}$ & 0.09 & 0.10 & 0.09 & & 5.0 \\
\hline $\mathrm{Hg}$ & 0.0008 & & & & \\
\hline $\mathrm{Li}$ & 0.3 & 1.0 & 0.3 & & 2.5 \\
\hline $\mathrm{Na}$ & 89.0 & 447.0 & 198.0 & & \\
\hline $\mathrm{Ni} \quad \vdots$ & & 0.016 & & & 0.20 \\
\hline $\left.\mathrm{NO}_{3}-\operatorname{las} \mathrm{N}\right)$ & 2.8 & 2.4 & 3.0 & & \\
\hline & & & & 0.4 & 0.02 \\
\hline $\mathrm{SO}_{4}{ }^{2-}$ & 81.0 & 65.0 & 63.0 & & \\
\hline $\mathbf{Z n}^{2}$ & & & & 2.0 & 2.0 \\
\hline TOS & 804.0 & 1742.0 & 1210.0 & & \\
\hline Temperature, ${ }^{\circ} \mathrm{C}$ & 12.0 & 25.0 & 12.0 & & \\
\hline
\end{tabular}

\footnotetext{
- Idaho National Engineering Laboratory, Environmental Report, Raft River Thermal Loop Facility, TREE-1144, 1977.

BMean of three wells from 3 to $16 \mathrm{~km}(2$ to 10 miles) upstream from RRGE.1 (S.G. Spencer, Idaho National Engineering Laboratory, personal communication, August 11, 1977).

'Mean of 14 wells within $3 \mathrm{~km}(2$ miles/ of RRGE-1 (S. G. Spencer, Idaho National Engineering Laboratory, personal communication, August 10-11, 1977).

Mean of five wells from 4 to $6 \mathrm{~km}$ (2.5 to 4 miles) downstream from RRGE-1 (S. G. Spencer, Idaho National Engineering Laboratory, personal communication, August 10-11, 1977).

- Mean of all 22 wells (S. G. Spencer, Idatio National Engineering Laboratory, personal communication, August 10-11, 1977).

'Committee on Water Quality Criteria, Water Quality Criteria 1972, EPA-R3-73-033.March 1873, Environmental Studies Board. National Academy of Science and National Academy of Engineering, 1972.
}

standards are given for comparison. Some reported levels of fluoride, chromium, selenium, and zinc are at or above recommended concentrations for Irrigation water. Most of the groundwater in the Raft River Valley is very hard, with very low levels of tron, manganese, and boron. 
Agricultural practices contribute large amounts of sulfate and nitrate to the groundwater. It has been suggested that certain parameters, such as temperature and total dissolved solids (TDS), Indicate leakage between shallow groundwater aquifers and deeper geothermal reservoirs. ${ }^{3}$ It is possible that some of the irrigation wells in the project area are tapping hot water in the upper part of the Salt Lake Formation.

\subsection{ATMOSPHERIC CHARACTERISTICS}

\subsubsection{Climate}

The climate of the Raft River Basin ranges from humid and subhumid In the higher mountains to semlarid on the floor of the Raft River Valley. The site of the proposed project is located on the valley floor, where the climate may be characterized as cold desert steppe. Climatic records from within the valley are sparse; the present discussion of climate is derived from data collected at the site, from climatic records for Malta and Strevell Included in the Environmertal Report, 3 and from the study by Walker et al.11

\subsubsection{Temperature and humidity}

Mean monthly temperatures in the Raft River Valley range from about $-3^{\circ} \mathrm{C}\left(26^{\circ} \mathrm{F}\right)$ in December-January to about $20^{\circ} \mathrm{C}\left(68^{\circ} \mathrm{F}\right)$ in July-August, with a mean annual temperature of $8^{\circ} \mathrm{C}\left(46.5^{\circ} \mathrm{F}\right)$. Extremes of $-27^{\circ} \mathrm{C}\left(-17^{\circ} \mathrm{F}\right)$ and $40^{\circ} \mathrm{C}\left(104^{\circ} \mathrm{F}\right)$ have been recorded in the valley. The growing season averages about 100 days. Humidity in the valley is fairly low. The highest humidities (about 70\%) are recorded in winter, the lowest (averaging 50\%) occur in sumer.

\subsubsection{Wind character1stics}

Although predominant reglonal alrflow is generally from the west, local wind characteristics in the Raft River Valley reflect the orfentation of the valley and the proximity of surrounding mountains. Malta is subject to winds from the west off the face of the Cotterell Range, 
while the predominant winds at Strevell come from the southeast, out of the Salt Lake Valley (F1g. 2.6). Winds tend also to be channeled through The Narrows of the Raft River, resulting in predominantly southwest winds at the project site (FIg. 2.6). A detailed wind rose for the site, based on approximately a year of data, is shown in Fig. 2.7. Wind speed averaged $4 \mathrm{~m} / \mathrm{sec}(9 \mathrm{mph})$; the average maximum 24-hour wind speed was $7 \mathrm{~m} / \mathrm{sec}$ ( $16 \mathrm{mph}$ ). Calms occurred InfrequentIy, less than $3 \%$ of the total time and generally between midnight and 6:00 AM.

Information about stability conditions near the site is limited. Regional information indicates that inversions occur about $40 \%$ of the time in sumer and $50 \%$ of the time in winter, which is typical of western mountain states. 17 Because of the generally clear skies, rapid evening ground cooling promotes nighttime inversions. Usually, morning heating of the ground by the sun and the fairly dependable daily winds may be expected to clear the inversion before afternoon. Since calms occur less than $3 \%$ of the time, dispersion capabllitles at the site are probebly good.

\subsubsection{Prec1pitation}

Preclpitation in the basin is derived mainly from winter storms moving eastward across the basin and, to a lesser degree, from sumer thunderstorms that generally come from the south or southwest, out of Utah and Nevada. The amount of annual precipitation depends upon alt1tude: the valley floor recelves $255 \mathrm{~mm}(10 \mathrm{ln}$ ) or less a year, but the ulgher mountains surrounding the valley may receive over $765 \mathrm{~mm}$ (30 in.) of annual precipitation, mostly as 6now.11 Records for Malta from 1965 to 1974 Indicate an average annual precipitation of $269.5 \mathrm{~mm}$ (10.6 In.). Streve11, Iocated In a pass between the Raft River Mountains and the Black PIne RIdge, approximately 235 m $(764 \mathrm{ft})$ higher than Halta, receives $301 \mathrm{~mm}(11.9 \mathrm{In}$ ) of preciptation annually. Snowfall in the valley occurs mainly between December and Apr11 and averages 966 m (38 in.) a year, with a moisture content of 7 to $20 \%$. 
ES 4123

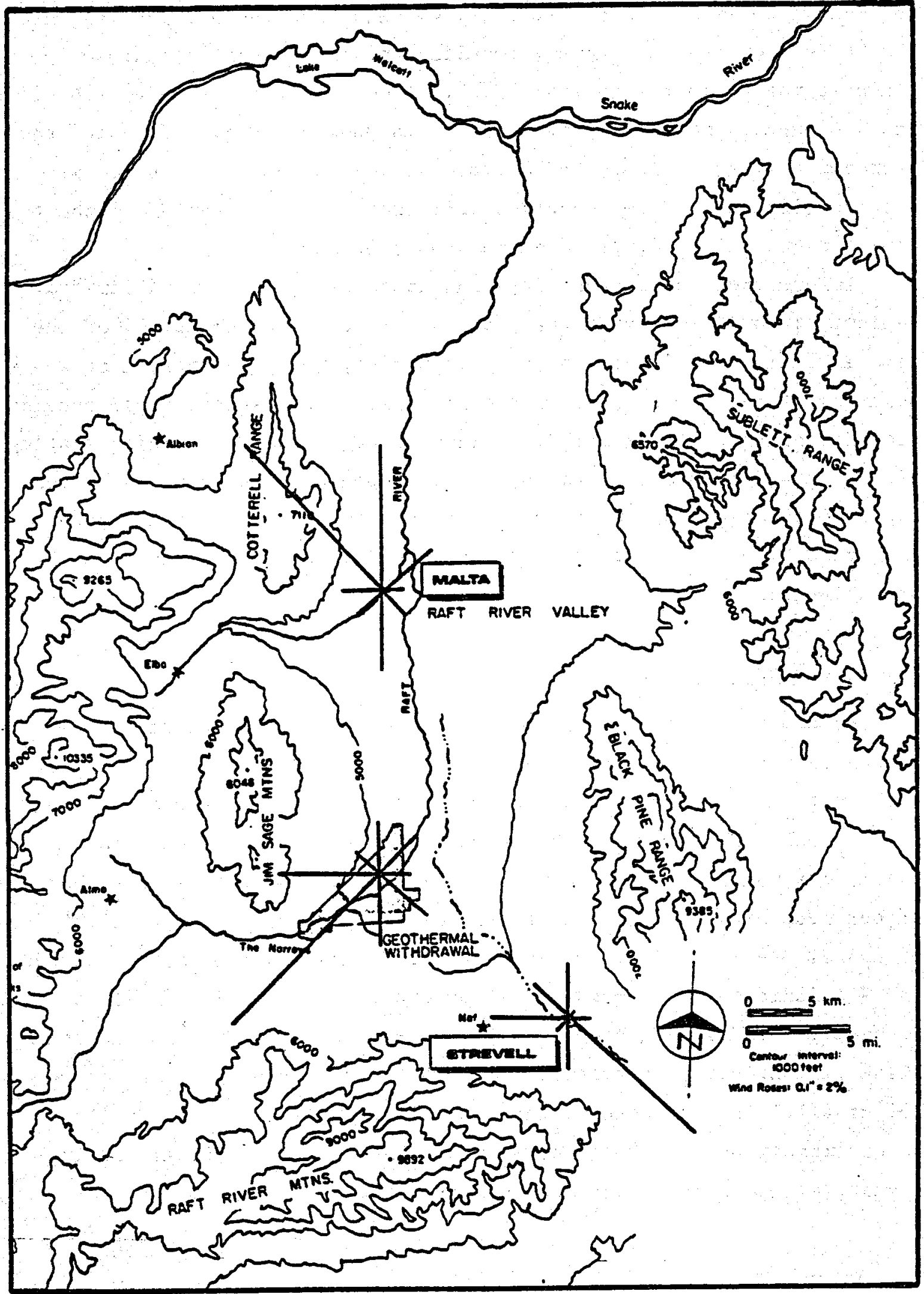

F1g. 2.6. Wind direction versus topography. Source: Idaho National Engineering Laboratory, Environmental Report, Raft River Thermal Loop Eacility, TREE-1144, 1977. 

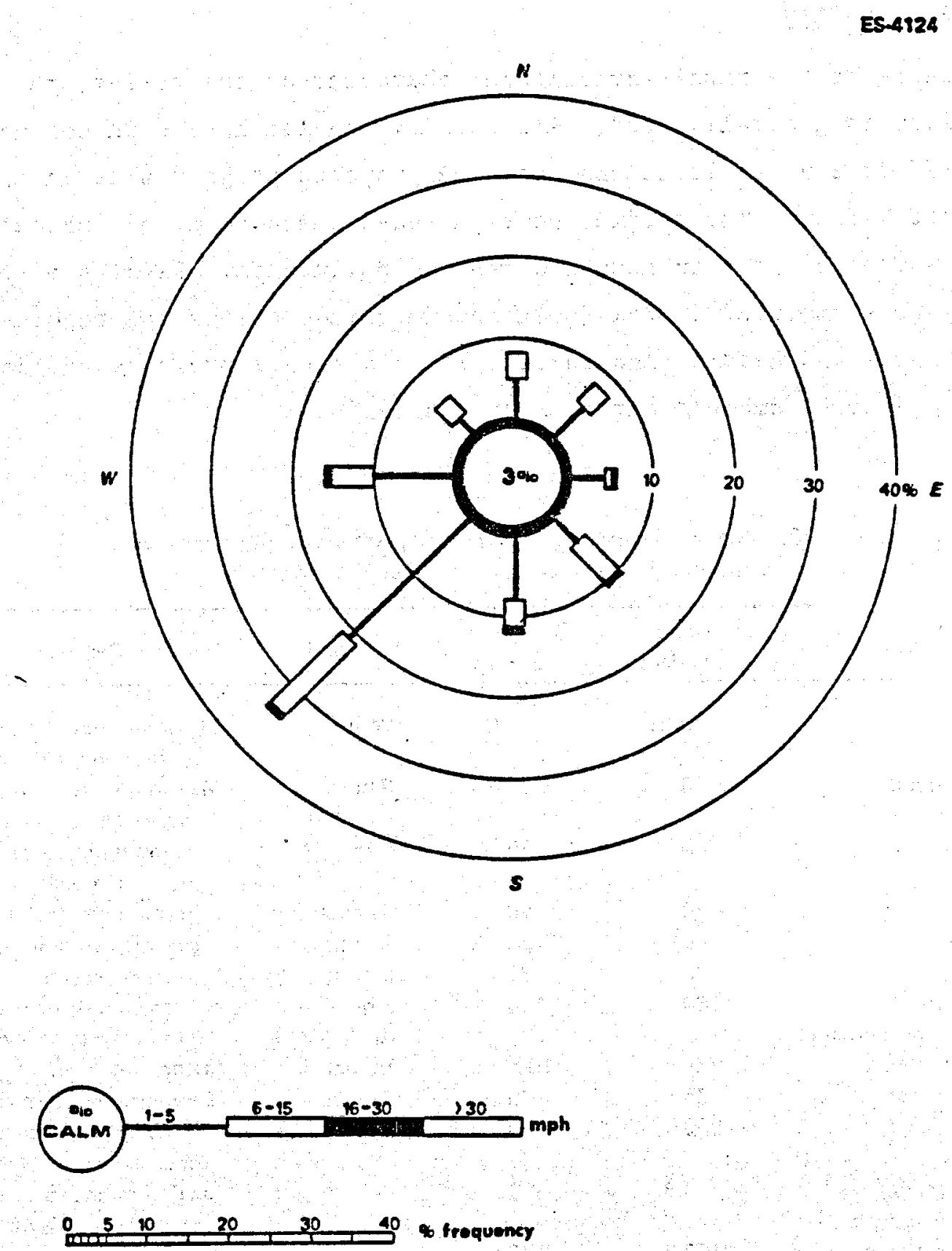

F1g. 2.7. Wind rose for RRGE-2, Source: Idaho Nat1onal Engineering Laboratory, Environmental Report, Raft River Thermal Ioop Facility. TREE-1144, 1977. 


\subsubsection{Air quality}

Because of the rural-agricultural character of the valley, the air quality is generally good. Alr quality studies have been conducted since 1975 at several locations near the proposed project site in the Raft River Valley. The studies have included measurement of ambient concentrations of particulates and gaseous pollutants. Results of the studies are sumarized in this section; detafled results are reported in the Enviromental Report ${ }^{3}$ and in ref. 18. Table 2.7 presents applicable state and Federal amblent alr quality standards.

Table 2.7. Idaho primary and secondary ambient air quality standards (Concentrations as $\mu \mathrm{g} / \mathrm{m}^{3}$ unless otherwise indicated)

\begin{tabular}{|c|c|c|c|c|}
\hline Pollutant & $\begin{array}{l}\text { Primary } \\
\text { standard }\end{array}$ & $\begin{array}{l}\text { Secondary } \\
\text { standard }\end{array}$ & Period & Remarks \\
\hline Beryllium & 0.01 & 0.01 & $24 \mathrm{hr}$ & $\begin{array}{l}\text { Maximum not to be exceeded } \\
\text { more than once a year }\end{array}$ \\
\hline \multirow[t]{2}{*}{$\begin{array}{l}\text { Carbon monoxide } \\
\left(\mathrm{mg} / \mathrm{m}^{3}\right)\end{array}$} & 10 & 10 & $8 \mathrm{hr}$ & $\begin{array}{l}\text { Maximum not to be exceeded } \\
\text { more than once a year }\end{array}$ \\
\hline & 40 & 40 & $1 \mathrm{hr}$ & $\begin{array}{l}\text { Maximum not to be exceeded } \\
\text { more than once a year }\end{array}$ \\
\hline $\begin{array}{l}\text { Fluorides" } \\
\text { (ppm, dry) }\end{array}$ & $\begin{array}{l}40 \\
60 \\
80\end{array}$ & $\begin{array}{l}40 \\
60 \\
80\end{array}$ & $\begin{array}{l}\text { Annual } \\
\text { Month } \\
\text { Month }\end{array}$ & $\begin{array}{l}\text { Arithmetic mean for two } \\
\text { consecutive months never } \\
\text { to be exceeded }\end{array}$ \\
\hline $\begin{array}{l}\text { Hydrocarbons } \\
\text { (corrected for methane) }\end{array}$ & 160 & 160 & $\begin{array}{l}3 \mathrm{hr} \\
(6-9 \text { AM) }\end{array}$ & $\begin{array}{l}\text { Maximum not to be exceeded } \\
\text { more than once a year }\end{array}$ \\
\hline Nitrogen dioxide & 100 & 100 & Annual & Arithmetic mean \\
\hline Particulate matter & $\begin{array}{r}75 \\
260\end{array}$ & $\begin{array}{r}60 \\
150\end{array}$ & $\begin{array}{l}\text { Annual } \\
24 \mathrm{hr}\end{array}$ & $\begin{array}{l}\text { Geometric mean maximum not } \\
\text { to be exceeded more than } \\
\text { once a year }\end{array}$ \\
\hline $\begin{array}{l}\text { Settleable particulates } \\
\text { (mg/cm per month) }\end{array}$ & 0.8 & 0.8 & . & $\begin{array}{l}\text { Maximum not to be exceeded } \\
\text { more than } 25 \% \text { of the time }\end{array}$ \\
\hline Photochemical oxidants & 160 & 160 & $1 \mathrm{hr}$ & $\begin{array}{l}\text { Maximum not to be exceeded } \\
\text { more than once a year }\end{array}$ \\
\hline \multirow[t]{2}{*}{ Sulfuric acid mist } & 12 & 12 & $24 \mathrm{hr}$ & $\begin{array}{l}\text { Maximum not to be exceeded } \\
\text { more than once a month }\end{array}$ \\
\hline & 30 & 30 & $1 \mathrm{hr}$ & $\begin{array}{l}\text { Maximum not to be exceeded } \\
\text { more than twice a week }\end{array}$ \\
\hline Sulfur oxides & $\begin{array}{r}80 \\
365\end{array}$ & 1300 & $\begin{array}{l}\text { Annual } \\
24 \mathrm{hr} \\
3 \mathrm{hr}\end{array}$ & $\begin{array}{l}\text { Arithmetic mean maximum not } \\
\text { to be exceeded more than } \\
\text { once a year }\end{array}$ \\
\hline
\end{tabular}

\footnotetext{
Those which result in total fluoride content in vegetation used for feed and forage.
} 
Total suspended particulates were measured daily at Malta, Naf, and at the Crank farm near the existing geothermal wells; results are sumarized in Table 2.8. Mean 24-hour partlculete concentrations ranged between 23 and $65 \mathrm{\mu g} / \mathrm{m}^{3}$ at these locatlons. The major component of the atmospheric particulates was soll dust. The source of this dust is in all likelihood unpaved roads and cultivated flelds in the valley. The 24-hour standard of $260 \mu \mathrm{g} / \mathrm{m}^{3}$ was exceeded twice at Malta in late June and corresponded to high values of $119 \mathrm{\mu g} / \mathrm{m}^{3}$ at the Crank farm. These high values probably occurred during high winds. Observed particulate concentrations are within the range that may be expected in similar rural-agricultural areas, as Indiceted by comparison with Table 2.9, which presents particulate concentrations at selected locations in southern Idaho.

Table 2.8. Dally hi-vol suspended particulate mass concentrations $\left(\mu \mathrm{d} / \mathrm{m}^{3}\right)$ in the Raft River Valley

\begin{tabular}{|c|c|c|c|c|c|c|}
\hline & $\begin{array}{l}\text { Number of } \\
\text { observetions }\end{array}$ & $\begin{array}{l}\text { High } \\
\text { value }\end{array}$ & $\begin{array}{l}\text { Low } \\
\text { value }\end{array}$ & $\begin{array}{l}\text { Arithmetic } \\
\text { mean }\end{array}$ & $\begin{array}{l}\text { Standard } \\
\text { deviation }\end{array}$ & $\begin{array}{l}\text { Geometric } \\
\text { mean }\end{array}$ \\
\hline $\begin{array}{l}\text { Malta } \\
\text { (July 30-Oct. 3, 1975) }\end{array}$ & 78 & 85 & 11 & 45.2 & 21.0 & 40.7 \\
\hline $\begin{array}{l}\text { Malta } \\
\text { (May 28-Aug. 26, 1876) }\end{array}$ & 91 & 384 & 16 & 64.7 & 46.1 & 55.9 \\
\hline $\begin{array}{l}\text { Crank } \\
\text { (May 28, 1976-Jan. 17, 1977) }\end{array}$ & 164 & 182 & 4 & 34.4 & 28.0 & 27.5 \\
\hline $\begin{array}{l}\text { Naf } \\
\text { (Oct. 21-Dec. 8, 1876) }\end{array}$ & 43 & 82 & 5 & 26.3 & 21.0 & 20.1 \\
\hline
\end{tabular}

Source: Environmental Studies Laboratory. University of Utah Research Institute, Baseline Environmental Studies in the Raft River Valley - 1976 Progress Report, 1977.

Concentrations of gaseous pollutants were measured in the vicinity of the RRGE-2 well for three weeks in late 1976 and early 1977. The well was flowing at the time, so the results may be somewhat higher than true background concentrations. Results are sumarlzed in Table 2.10 . Concentrations of all pollutents measured were well below primary amblent 
Table 2.9. Panticulate concentrations dotermined by the hi-ol method for varlous loeations in Ideho in 1972

\begin{tabular}{|c|c|c|c|c|c|c|c|}
\hline Location & $\begin{array}{c}\text { Site } \\
\text { designation }\end{array}$ & Type & $\begin{array}{l}\text { Number of } \\
\text { measurements }\end{array}$ & $\begin{array}{c}\text { Average } \\
\text { concentration } \\
\left(\mu \mathrm{g} / \mathrm{m}^{3}\right)\end{array}$ & $\begin{array}{c}\text { Mean } \\
\text { standerd } \\
\text { deviation }\end{array}$ & $\begin{array}{c}\text { Maximum } \\
\text { concentration } \\
\left(\mu \mathrm{g} / \mathrm{m}^{3}\right)\end{array}$ & $\begin{array}{c}\text { Minimum } \\
\text { concentration } \\
\left(\mu \mathrm{g} / \mathrm{m}^{3}\right)\end{array}$ \\
\hline $\begin{array}{l}\text { Twin Falls } \\
\text { (321 2nd Avo.) }\end{array}$ & $001 \mathrm{Fo1}$ & Conter city & 137 & 118.1 & 1.8 & 485 & 28 \\
\hline $\begin{array}{l}\text { Twin Falls } \\
\text { (5 miles east) }\end{array}$ & $001 \mathrm{F03}$ & Rural-agricultural & 100 & 45.6 & 2.1 & 221 & 10 \\
\hline Ada County & 001 F03 & Rural-agriculturat & 113 & 39.3 & 1.8 & 243 & 6 \\
\hline $\begin{array}{l}\text { Nampa } \\
\text { (923 1st So.) }\end{array}$ & 001 F01 & Center city & 87 & 113.7 & 2.0 & 534 & 19 \\
\hline $\begin{array}{l}\text { Butte County } \\
\text { (craters of the moon) }\end{array}$ & $001 \mathrm{A03}$ & Remote & 28 & 10.8 & 1.8 & 35 & 3 \\
\hline $\begin{array}{l}\text { Caribou Counny } \\
\text { (near Soda Springs) }\end{array}$ & 002 F02 & Rural-agricultur al & 100 & 36.3 & 2.2 & 237 & 6 \\
\hline $\begin{array}{l}\text { Idaho Falls } \\
\text { (C Street and Shoupe) }\end{array}$ & $004 \mathrm{FO1}$ & Conter city & 130 & 89.2 & 1.7 & 303 & 27 \\
\hline
\end{tabular}

Source: Environmental Studies Laboratory. University of Utah Research Institute, Baseline Environmentel Snidies in the Raft Aiver Valley - 1976 Progress Report, 1977. 
Table 2.10. Average 24hr concentrations of various environmental pollutants near RRGE-2, Raft River $\left(\mu \mathrm{g} / \mathrm{m}^{3}\right)$

\begin{tabular}{cccccccccc}
\hline Dates & $\begin{array}{l}\text { Total } \\
\text { sulfur } \\
\text { species }\end{array}$ & $\mathrm{H}_{2} \mathrm{~S}$ & $\mathrm{SO}_{2}$ & $\begin{array}{c}\text { Ammonium } \\
\text { sulfate }\end{array}$ & $\mathrm{NO}_{2}$ & $\mathrm{NO}$ & $\mathrm{NO}_{\mathbf{x}}$ & $\mathrm{O}_{3}$ \\
\hline $12 / 17-18 / 76$ & $48.4 \pm 4.9$ & $18.3 \pm 3.9$ & $12.5 \pm 1.3$ & 1.25 & 3.2 & 0.3 & 3.5 & 58.8 \\
$12 / 22-23 / 76$ & $36.4 \pm 3.6$ & $11.9 \pm 2.4$ & $13.5 \pm 1.4$ & 0.74 & 6.1 & 0 & 6.1 & 61.9 \\
$12 / 29-30 / 76$ & $14.3 \pm 1.4$ & $3.3 \pm 0.7$ & $7.8 \pm 0.8$ & 0.54 & 3.6 & 0.8 & 4.4 & 37.8 \\
$11 / 3-4 / 77$ & $16.9 \pm 1.7$ & $7.8 \pm 1.6$ & $2.1 \pm 0.2$ & 0.32 & 3.0 & 0.1 & 3.1 & 66.4 \\
\hline
\end{tabular}

Source: Environmental Studies Laboratory, University of Utah Research Institute, Baseline Environmental Studies in the Raft River Valley - 1976 Progress Report, 1977.

air quality standards (Table 2.7), as may be expected in an area of low traffic, far from a major industrial center.

\subsection{NOISE}

Noise is defined as any undesirable sound; for analytical purposes, It is assumed to decrease in desirability as loudness increases. Loudness (intensity) of sound is measured in dectbels (dB) using a logarithmic scale of comparative intensity with respect to the threshold of human hearing. Using this scale, an increment of $1 \mathrm{~dB}$ corresponds to an increase of $26 \%$ in intensity. Table 2.11 gives some common sound levels.

The human ear percelves sounds of intermediate frequency (1000 to $4000 \mathrm{~Hz}$ ) at lower intensity than those of low and high frequency; therefore, nolse measurements are usually welghted to account for this by using the "A" (dBA) scale. No1se impacts on humans depend to a high degree on individusl variation in acuity and personal experience as well as on Intensity and frequency of the noise. Wildiffe also differ greatly in their sensitivity. to various frequencies and intensities. 19

An unmuffled venting steam well may cause nolse levels of 120 dBA $31 \mathrm{~m}$ (100 ft) away. 20 Nolse levels from the liquid-dominated resource at Raft RIver are not expected to exceed $100 \mathrm{dBA}$ at $15 \mathrm{~m}(50 \mathrm{ft})$. A large proportion of the sound energy (Intensity) emanating from geothermal well venting is in the lower frequency range of the noise spectrum. 
Table 2.11. Typical "A"-woighted sound levels and human responses

\begin{tabular}{|c|c|c|c|}
\hline Sound source & $\mathrm{dBA}$ & Response criteria & $\begin{array}{l}\text { Intensity } \\
\left(\mu W / m^{2}\right)\end{array}$ \\
\hline Carrier deck jet operation & 150 & & $10^{\circ}$ \\
\hline & 140 & $\begin{array}{l}\text { Painfully loud; limited } \\
\text { amplified speech }\end{array}$ & $10^{8}$ \\
\hline & 130 & & $10^{7}$ \\
\hline Jet takeoff $(200 \mathrm{ft})$ & & Maximum vocal effort & \\
\hline & 120 & & $10^{6}$ \\
\hline Discotheque & 110 & & $10^{5}$ \\
\hline $\begin{array}{l}\text { Jet takeoff }(2000 \mathrm{ft}) \\
\text { Shout }(0.5 \mathrm{ft})\end{array}$ & & & \\
\hline & 100 & & $10^{4}$ \\
\hline Heavy truck $(50 \mathrm{ft})$ & & $\begin{array}{l}\text { Very annoying, hearing } \\
\text { damage ( } 8 \mathrm{hr})\end{array}$ & \\
\hline & 90 & & $10^{3}$ \\
\hline Pneumatic drill $(50 \mathrm{ft})$ & 80 & Annoying & $10^{2}$ \\
\hline Freight train $(50 \mathrm{ft})$ & & & \\
\hline Freeway traffic $(50 \mathrm{ft})$ & & $\begin{array}{l}\text { Telephone use difficult: } \\
\text { intrusive }\end{array}$ & \\
\hline & 70 & & $10^{1}$ \\
\hline \multicolumn{4}{|l|}{ Air conditioning unit (20 ft) } \\
\hline Light auto traffic $(50 \mathrm{ft})$ & 60 & Quiet & \\
\hline $\begin{array}{l}\text { Living room } \\
\text { Bedroom }\end{array}$ & 50 & & $10^{-1}$ \\
\hline & 40 & & $10^{-2}$ \\
\hline $\begin{array}{l}\text { Library } \\
\text { Soft whisper (15 ft) }\end{array}$ & & Very quiet & \\
\hline & $\begin{array}{l}30 \\
20\end{array}$ & & $\begin{array}{l}10^{-3} \\
10^{-4}\end{array}$ \\
\hline Broadcasting studio & 10 & Just audible & $10^{-8}$ \\
\hline & 0 & Threshold of hearing & $10^{-6}$ \\
\hline
\end{tabular}

-Typical A-weighted sound levels taken with a sound level meter and expressed as decibels on the scale. The "A" scale approximates the frequency response of the human ear.

Source: Environmental Quality - The First Annual Report of the Council on Environmental Quality, Council on Environmental Quality, transmitted to Congress August 1970. 
Because of this, the A scale tends to minimize potentiel noise impacts on wildiffe whose level of perception is generally unknown but is of ten broader than that of humans. Also, low-frequency, high-intensity noise may have subliminal or psychological effects on humans. The A scale weighting is nonetheless used for all standards and criteria and is the only index that can be used to assess noise Impact.

\subsubsection{Nolse characteristics of the site}

Due to the low population density and rural character of the Raft River Valley, baseline nolse levels are low. The primary nolse source is agricultural operations, and important secondary sources include vehicle traffic and wind. Sound level messurements which averaged $40 \mathrm{dBA}$ were dominated by two tractors operating withth $0.8 \mathrm{~km}$ ( $0.5 \mathrm{miles}$ ) of the measurement location. In the absence of such human activity, sound levels would measure approximately $20 \mathrm{dBA}$.

\subsubsection{No1se regulations}

This assessment 15 concerned with commulty nolse. The province of worker habitat and Its relationship to tools and machinery is administered by the Federal Department of Labor under the Occupational Safety and Health Act (May 29, 1971). Neither the State of Idaho nor Cassia County has specific regulations regarding commutty nolse. In the absence of local guldelines, the Environmental Protection Agency (EPA) has recomended that maximum sound levels be matntained between 78 and $82 \mathrm{~dB}$ or as low as practicable. Because of the danger to health, sound levels above 90 aB are prohiblted. The following Department of Eousing and Urban Development rating systell for nolse levels at residences Is also applicable:

1. Clearly unacceptable: exceeds 80 dBA for $60 \mathrm{~min}$. In a 24-hr perlod, or exceeds $75 \mathrm{dBA}$ for $8 \mathrm{hr}$ in a 24-hr time span.

2. Normally unacceptable: exceeds 65 aBA for 9 hr in a 24-hr time span, or loud repetitive sounds onsite. 
3. Normally acceptable: exceeds $65 \mathrm{dBA}$ for less than $8 \mathrm{hr}$ in a 24-hr perfod.

4. Clearly acceptable: does not exceed 45 dBA for more than 30 min. in a 24-hr period.

\subsection{ECOLOGY}

\subsubsection{Terrestrial ecology}

Plant communities in the Raft River Basin are those typical of much of the Great Basin: shrub communitles dominate the lower slopes and valley floor, and pinyon-junlper woodlands cover the upper slopes and foothills of the surrounding mountains. Animals thet typically occur in semiarid shrublands of the Great Basin would be expected to occur in the Raft River Valley.

\subsubsection{Vegetation}

The vegetation over approximately 29,000 ha $(74,000$ acres) surrounding the withdrawal area was mapped from aerlal photographs and fleld studies. 3 Thirteen distinct plant communties were Identified in the Raft River Basin; a complete plant species 11st may be found in Appendix D of the Envirormental Report. ${ }^{3}$ since much of the $290 \mathrm{~km}^{2}$ (115 sq miles) of the mapped area was outside the boundaries of the withdrawal area, not all thirteen plant comunities are represented within the withdrawal area proper. Two shrub specles dominate the vegetation of the natural communities within the withdrawal area: b1g sagebrush (Artemesia tridentata) and greasewood (Scroobatus vermiculatis). Greasewood-dominated commities occur on flat areas and gentle slopes on the valley floor, where soils are slightly alkaline. The big sagebrush type occurs on better-drained, less alkaline solls along drainages that finger through the aree. Sagebrush becomes a continuous type at higher elevations on the lower slopes of the mountains surrounding the Raft River Valley. Large ecotonal areas of mixed greasewood-sagebrush occur between the two types. The understory of both shrub comminities consists primarily of squirreltall grass (Sitanion hysterix), sandberg 
bluegrass (Poa scondbergii), Tansy mustard (Descurainia sp.), and some prickly pear (Opuntia polyacantha). Annuals that occur most frequently include cheatgress (Bromus tectorm), Russian thistle (Salsola kali), and pepperweed (Lepidium perfoliatum). Gressewood and sagebrush communitles cover well over $50 \%$ of the area of the withdrawal. Squirreltall grass (Sitanion hysterix), and Tansy mustard (Descurainia sp.) generally make up the typtcally sparse understory of grass and shrubs. The pinyon-funiper woodlands and the ecotonal area between the woodlands and big sagebrush commulties are excellent wildilfe habitat.

\subsubsection{Antmals}

Survey studies of vertebrate species have been conducted within the withdrawal area; detafled results of these surveys and complete species IIsts are avallable in the Environnental Report. 3 Animals that occur in the Raft River Valley are those that are typical of semiarid shrublands of the Great Basin desert. These shrub communitles have a surprising density and diversity of small mamals, primarily rodents. From 12 to 15 rodent species, with total rodent densities ranging from 15 to 40 per hectare, have been recorded from shrub habitats in the Great Basin.21,22 Ten species of rodents were observed in the Raft River Valley, the most comon being the deer mouse (Peromyscus moniculatis), pocket mouse (Perognathus parvus), the least chlpmunk (Eutamias minimus), and Ord's kangaroo rat (Dipodomys ordii). 3 Rabbits are conspicuous members of shrub commulties and are important prey for both mammalian and avian predators. Both the black-tall jackrabb1t (Lepus califorricus) and the cottontall (Sylvilagus nuttali) are comon in the Raft River Valley. Two species of predatory mamals were observed on the withdrawal erea: the coyote (Canis latrans) and the badger (Taxidea tarus). 3

Although the withdrawal area 16 not important range for big game, some habltat for both mule deer (Odocoileus hemionus) and pronghorned antelope (Antilocapra anericana) is present near the withdrawal area. On the east blopes of the Jim Sage Mounteins, the pinyon-juniper woodlands and the ecotone between the woodlands and the bIg sagebrush communities are excellent mule deer habitat. These slopes are considered 
by the U.S. Fish and Wildife Service to be crucial winter habitat for deer. 23 There is a small herd of pronghorned antelope that utilizes the lower portion of the western and eastern slopes of the Raft River Valley. Antelope may occasionally enter the withdrawal area. Ridding areas for this herd are located outslde the withdrawal area, south of the valley near the Raft River Mountains.

The same area on the east slopes of the Jim Sage Mountains that is good deer habitat 15 also important to game birds. Both the chukar partridge (Alectoris graeca) and the Hungarlan partridge (Perdis perdir) utIlize these slopes. Although sage grouse (Centrocercus urophasionus) are widely scattered throughout the withdrawal area, their preferred habltat is in dense sagebrush cover along drainages and on the slopes to the west of the withdrawal. Strutting grounds and brood rearing areas are on these slopes west of the withdrawal. 23 Mourning doves (Zenaida macroura) are common throughout the valley, but are concentrated near " springs, developed watering sites, and grain flelds. Ringnecked pheasants (Phasiconus colchicus) also use the grain fields on the withdrawal area. 3

The Raft Rtver Valley is good raptor habitat. Bird surveys conducted from September 1975 to July 1976 reported observations of 15 specles of raptors within $8 \mathrm{~km}(5 \mathrm{miles})$ of the withdrawal area. 3 Bald eagles (Haliaeetus leucocephalus) winter in the Raft River Valley and golden eagles (Aquila chrysaetos) are year-round residents. The most notable hawk that occurs in the Raft River Valley is the ferruginous hawk (Buteo regalis), largest of the North American hawks. Ferruginous hawks, for the most part, nest in junipers on the east slopes of the Jim Sage Mountains and on the west slope of the Black Pine Mountalns. 23 However, one ferruginous hawk nest is documented (no longer existing) in the southern part of the withdrawal area in a cottonwood tree next to the river. The withdrawal area also provides habitat for a number of species of songbirds. The most abundant songbirds are horned larks (Eremophila alpestris), western meadowlarks (Sturnella neglecta), Brewer's blackbirds (Euphagus cyonocephalus), Brewer's sparrows (Spizella breweri), and säge sparrows (Amphispiza belli). ${ }^{3}$ 


\section{5 .2 Aguatic ecology}

The most important aquatic habitat in the vicinity of the project area is the Raft River (Sect. 2.2.1). Fish species present in the river include cutthroat trout (Salmo clarki), mottled sculpin (Cottus bairdi), redside shiner (Richardsonius balteatus), speckled and longnose dace (Rhinichthys osculus and cataractae), and Utah and mountain sucker (Catostomus ardens and platyrhynchus), according to electroshocking sampling of two 100-m sections during Februsry 1977.24 The fish communtey in the shallow ( 0.03 to $0.5 \mathrm{~m}$ deep) Ifffle-pool reach near The Narrows, at the couthwestern corner of the project area, was dominated by dace ( $38 \%$ of captured Individuals), sculpins (37\%), and suckers ( $21 \%$ ). Smaller numbers of shiners and trout were taken. Further downstream, approximately in the center of the project area, the stream was deeper $(0.01$ to $1.0 \mathrm{~m})$ and contained no riffle areas. The fish commuity was dominated by shiners (49\%) and suckers (36\%), with the remainder of the fish being dace ( $15 \%)$; no trout or sculp in were taken.

The Raft River in the vicinity of the project area is considered poor fishery habitat. 23 Brown trout (Salmo tmutta) fingerlings stocked in the Raft RIver by the Idaho Fish and Game Department in 1973 were not detected in the February 1977 sampling. 3 Trout flshing on the Raft River 1s 1ight. 24 Cassia Creek, a downstream tributary to the Raft River, does provide a good fishery, however, and 1s regularly stocked by the State. 23

The poor fishery potential of the Raft Rfver can probably be related to such factors as low flow (Sect. 2.2.1); lack of sultable habltat and cover (the bottom substrate is primarily anoxic silt-mud up to $0.5 \mathrm{~m}$ deep and little macrophyte or overhanging vegetation is present), high suspended solids load, and limited Invertebrate populations. Kicksampling at four locetlons (two within the project area, one each upstream and downstream from the project area) ylelded only ten organisms in 30 sampling attempts. Quantitative sampling in selected riffles near the four sampling locations Indicated an invertebrate communty consisting primarlly of caddisfly larvae and mayfly and stonefly nymph, with lesser numbers of midge, crane fly, and dragonfly Imatures. Water mites, snails, and clams were also found. 25 Population densities at the four 
sampling sites were found to decrease in a downstream direction, from 1840 Individuals per square meter at the upstream site to 873 individuals per square meter at the downstream site. 25

The aquatic flora of the Raft River in the vicinity of the project area is dominated by diatoms, of which 85 spectes were 1dentified. 26 The diatom communities (dominated by Nitzschia palea, Navioula rhyncocephata, and Epithema sorex) were generally similar in composition over the length of the sampled portion of the Rtver, and fncluded eplpelic (living-on-mud) genera which reportedly characterize silt babitat in alkaline streams. 27 Other algae reported Included blue greens (Oscillatoria agardhii) and greens (Cladophora glomerata and Spirogyra commonis). The only rooted plant reported was the stinkwort Chora vulgaris, which occurs in silted, hard-water streams. 27 The blue-green alga Lyngbya, comon in warm waters, 27 was found in the effluent from the (hot) BLM well.26 Riparian vegetation includes bulrush (Scirpus), willow (Salix), and cattall. (Typha), although riparian habitat is not as extensive along the Raft River as it is along other area streams. 23

Caddisflies, snails, and clams taken from the Raft River, Big Springs (Island Park, Idaho), and the Snake RIver (Burley, Idaho) were analyzed for trace element concentration. 25 Although the data are difficult to interpret because of small sample size $\mathrm{s}^{3}$ and because of possible contribution of gut contents, 28 trace element concentrations appeared highest in caddisflies and clams from the Raft River. The situation was less obvious for snalls, with concentrations reported for the Big Springs or Raft River samples greater for various trace elements.

\subsubsection{Endangered species}

Only one specles 11sted as endangered or threatened by the Federal goverment is known to occupy the Raft River Valley.29,30 Bald eagles (Ealiaeetus leucocephalus) are infrequent but regular winter visitors to the valley. This low level of use and the character of the valley suggest that it does not constitute critical habitat for the species.

Wh1le no peregrine falcons (Falco peregrinus) were seen during the ecological survey, this species only recently ceased nesting in this 
region. An attempt is now being made to reintroduce the species into southern Idaho by placing young peregrines in the nests of other raptors In the Birds of Prey Natural Area. This area is $240 \mathrm{~km}$ (150 miles) from the Raft River Valley. Within the life of the project; peregrine falcons may return to the area, but the valley is not prime habitat so they would probably never become common.

Prairle falcons (Falco mexicams) have recently been removed from the list of threatened specles and ferruginous hawks (Buteo regalis) have been proposed for inclusion in that 11st. Both species are yearround residents of the valley.

None of the plant specles on the proposed list of endangered and threatened plants are known to occur in the valley. 31 Some may be present as seed which only germinate following exceptlonally heavy precipitation.

\subsection{LAND USE}

The major land owner in the Raft River Valley is the Federal government. All Federal land in the vicinity of the withdrawal is managed by the Bureau of Land Management (BIM). Privately owned land in the withdrawal area is concentrated along the river, as is most private land within the entire valley (FIg. 2.8). Approximately $43 \%$ of the withdrawal area is privately owned. Most of this private land is leased for geothermal development by the Raft River Rural Electric Cooperative, Sun 011 Co.s or Steam Corporation of Amerlca; some leases are under content1on. Some areas are leased for 011 and ges development, but the poor results of the three exploratory gas wells drilled to date have discouraged further exploration.

Wuch of the private land along the Raft RIver is currently under irrigated cultivation. While the topography permits flood Irrigation, most of the land is 1rrigated with sprinklers. The major crops are wheat, barley, alfalfa, and hay. Although an estimated $1400 \mathrm{~km}^{2}$ (340,000 acres) of undeveloped IrrIgable land exists in the valley, the moratorium on groundwater development has stopped development of new crop 1and. Approximately 720 ha (1800 acres) of private land within the geothermal withdrawal is irrigated. 


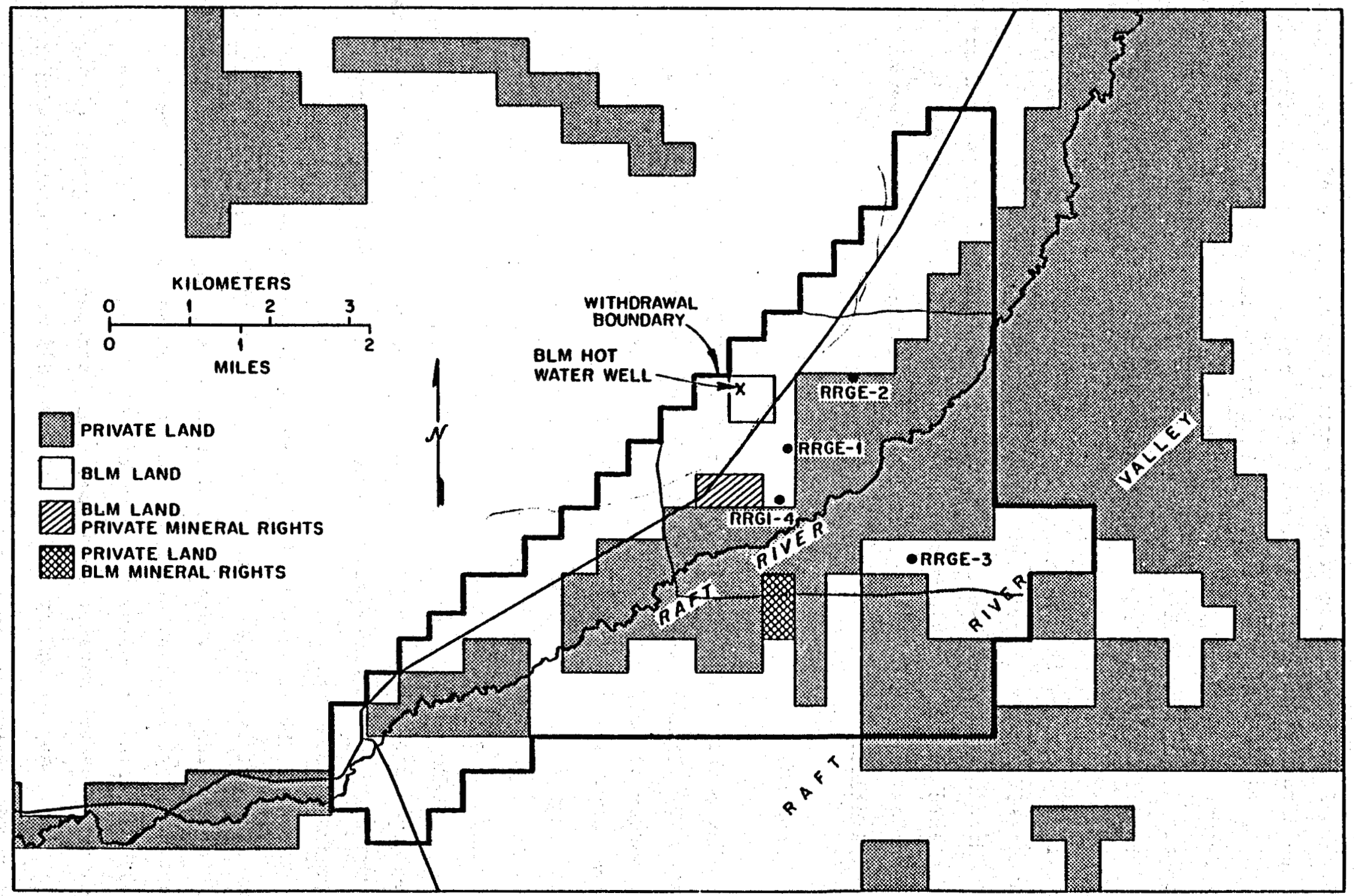

F1g. 2.8. Land ownership in the geothermal withdrawal area. Source: Idaho National Engineering Laboratory, Environmental Report, Raft River Thermal Loop Facility, TREE-1144, 1977. 
There is no industry in the valley because of the limited agricultural base, water supply, and labor force.

Most of the BLM-controlled land is classified for multiple use. Currently the only significant use of the land $1 \mathrm{~s}$ livestock grazing. In the Jim Sage and Cotterell ranges and on other steep slopes, grazing is impossible. The upper portions of the Jim Sage Mountains are high, rugged, and relatively undisturbed. A proposal to designate these mountains as e primitive area was rejected because they are not regionally unique. The BIM Is currently considering their claseification as a natural area. Most of the state lands in the area are leased for grazing.

The greatest recreational attraction in the area is the City of Rocks State Park, approximately $21.5 \mathrm{~km}$ (13 wiles) west of the withdrawal. No records are kept of visitation, but it is believed to amount to several thousand visitor days per year:

Within the geothermal withdrawal ares, the Bureau of Land Management (BLM) has identified a site at the BLM hot water well as a potential recreation area. To preserve this use, the BLM has set aside the NW $1 / 4$ of Sect. 23, T15S, R26E (F1g, 2.8) agrinst competing uses. No use is currently made of the ares.

Some birds, small game, antelope, and deer are hunted in the area, largely by local residents. Trout flshing is avallable in upper Cassia creek.

Access to the geothermal withdrawal erea is provided by State Highway 81, which runs from Burley to Malta and south into Utah. State Highway 77 runs from Malta to Almo and passes through the withdrawal. other roads are county or private and are generally unpaved.

\subsubsection{Prime and unique farmlands}

Prime and unique farmlands within the Raft River Valley will not be designated by the Department of Agriculture unt11 a soll survey has been completed. 


\subsubsection{Aesthetics}

The Raft River Valley is typical of many Great Basin Valleys: a flat to gently rolling valley floor rises to surrounding mountains ranging up to $1500 \mathrm{~m}(5000 \mathrm{ft})$ above the valley floor. Despite the agricultural development in the valley floor, the area maintalns a natural appearance. While shrub steppe vegetation dominates the valley and lower slopes, pinyon-juniper, aspen, and douglas fir woodlands in the mountains provide variety. The most dramatic aesthetic resource in the area, the City of Rocks, is separated from the geothermal withdrawal by mountains. The low nolse level and good alr quality of the valley enhance its aesthetic appeal.

The visual qualities of the Raft River Valley, other than the City of Rocks, are not unusual and would not be 11kely to attract visitors. However, responses of the Electrlc Co-op members to the geothermal development questionnaire Indicate that the unspoiled character of the valley is important to many of its residents. 32 In response to the question, "If you were able to control the future, what would you keep from changing in the valley," the most frequent response was "the rural character," and the third most frequent was "the natural enviroment."

\subsection{WATER USE}

Water for irrigation was obtained initially from streamflow diversion, but by the 1940 s pumping of groundwater became the dominant source. As a result of the withdrawal of groundwater and streamflow diversion, most of the flow of the Raft River is depleted by direct use and percolation to replace groundwater. Annual hydrologic budgets of the Raft River Basin, in both the natural and developed state, are presented in Sect. 2.2.1.

Groundwater use in the basin has been estimated at about $2.9 \times 10^{8} \mathrm{~m}^{3} /$ year $\left(2.35 \times 10^{5}\right.$ acre-ft/year) for 1966 , pumped from more than 300 wells. 11 Domestic water consumption has been estimated at $1.2 \times 10^{5} \mathrm{~m}^{3} /$ year (100 acre-ft/year), a much smaller amount than that used for irrigation. ${ }^{3}$ No municipal water systems are present in the Raft River Basin. 
Current groundwater withdrawals in the project area total about $4.4 \times 10^{6} \mathrm{~m}^{3} /$ year (3600 acre-ft/year), pumped from about 15 wells; this water is used for the Irrigation of privately owned land. Additionally, because of the acceptable quality of the geothermal waters so far extracted, local farmers have been able to use the cooled water for Irrigation and stock watering, supplementing pumped groundwater. The flows from the BLM and Crank (hot) wells, estimated at 3.8 liters/sec (60 gPI) each, have been used for Irrigation, stock watering, and greenhouse heating. Farmers also use ebout $4.4 \times 10^{4} \mathrm{~m}^{3} /$ year (36 acre-ft) year) of geothermal waters from well RRGE-1 for IrrIgation. 33

Aquaculture and soll cooling experiments planned in the project area, but not part of the pllot plant 1tself, will require the use of small amounts of geothermal fluid. These activities will be located near well RRGE-1, from which the fluids will be taken. The aquaculture experiment will require 6.3 liters/sec (100 gpm) and will continue from September 1977 to Apr11 1978; during this time no more than $1.3 \times 10^{5} \mathrm{~m}^{3}$ (105 acre-ft) w11l be needed. The soll cooling experiment, which will run for about three years, w111 require 0.6 to 1.311 ters/sec (10 to $20 \mathrm{gpm}$. Annual use has been estimated at $7.4 \times 10^{3} \mathrm{~m}^{3}$ (6 acre-ft).

Uses of the Raft River to be protected according to Its Class A designation by the state are 11sted in sect. 2.2.1. There is 1ight trout flshing on the Raft River, although the poor fishery status of the river (Sect. 2.5.2) Iimits this activity.

The State of Idaho owns all water resources withtn the state. Speciflc rights are obtalned by appropriation and are administered by the Department of Water Resources. Riparian rights may be exerclsed only to the extent that they do not interfere with appropriated rights. Ifmited water withdrawels for domest1c purposes [up to $4.9 \times 10^{4}$ 11ters/day $\left.\left(1.3 \times 10^{4} \mathrm{gpd}\right)\right]$ are permitted, whth the rights obtained by withdrawal and use subject to inspection by the Department of Water Resources and the Department of Health and Welfare. Groundwater righto for drainage purposes are also exempted from the appropriation procedure. Since 1963, the Raft River Basin has been declared a critical groundwater area by the state because of the uncertalnty of whether the supply w11 satisfy existing and pending water rights. No further approprietions of water 
rights have been permitted. Rights to the flow from the BLM, Crark, and groundwater wells in the project area are all approprlated. 33

\subsection{DEMOGRAPHY AND SOCIOECONOMICS}

The geothermal project is located in the southern portion of Cassia County, Idaho (FIg. 2.9). The area is rural; the two largest nearby commuities, Malta and Albion, have populations of 192 and 226 respectively. Malta is $24 \mathrm{~km}$ ( 15 miles) from the site; Albion is $55 \mathrm{~km}$ (34 miles) away. Other comminities within commuting range are Almo (population approximately 40), $27 \mathrm{~km}$ (17 miles) away; Elba (population estimated at 25), $43 \mathrm{~km}$ (27 miles) away; Naf (population 25), $18 \mathrm{~km}$ (11 miles) away; Sublett (population also approximately 25), $40 \mathrm{~km}$ (25 miles) away; and Declo (population 352), $66 \mathrm{~km}$ (41 miles) away (FIg. 2.9). Total population for the Raft River and Albion valleys, as estimated from the number of telephone connections in the Malta, Albion, Almo, and Elba exchanges, is approximately 1500. From these estimates, nearly two-thirds of the population of the area lives outside the communities 11sted, on farms and ranches. The population density within a $16-k m$ (10-mile) radius of RRGE-1 is 0.2 people per square kilometer ( 0.5 people per square mile). There are five occupled residences on private land within the geothermal withdrawal and several cottages for mlgrant farm workers.

On the county level, the population density of 2.8 people per square kilometer ( 7.2 people per square mile) is near the average for the state of Idaho. Typical of the state as a whole, Cassla County has many square miles of sparsely populated land surrounding an urban trade area of modest size. The largest city in the county is Burley, population 8771 (in 1976), approximately $80 \mathrm{~km}$ (50 miles) away. Most of the population, manufacturing, retall, and goverment centers are located in the northern end of the county, on the Snake River Plain. The county growth rate during the pertod 1970-1975 was only 1.5\% (Table 2.12).

Access to the valley is provided by Interstate Highway $80 \mathrm{~N}$ and State Highways 81 and 77. A large number of unpaved roads accomodate most movement within the valley, including access to the withdrawal. A 


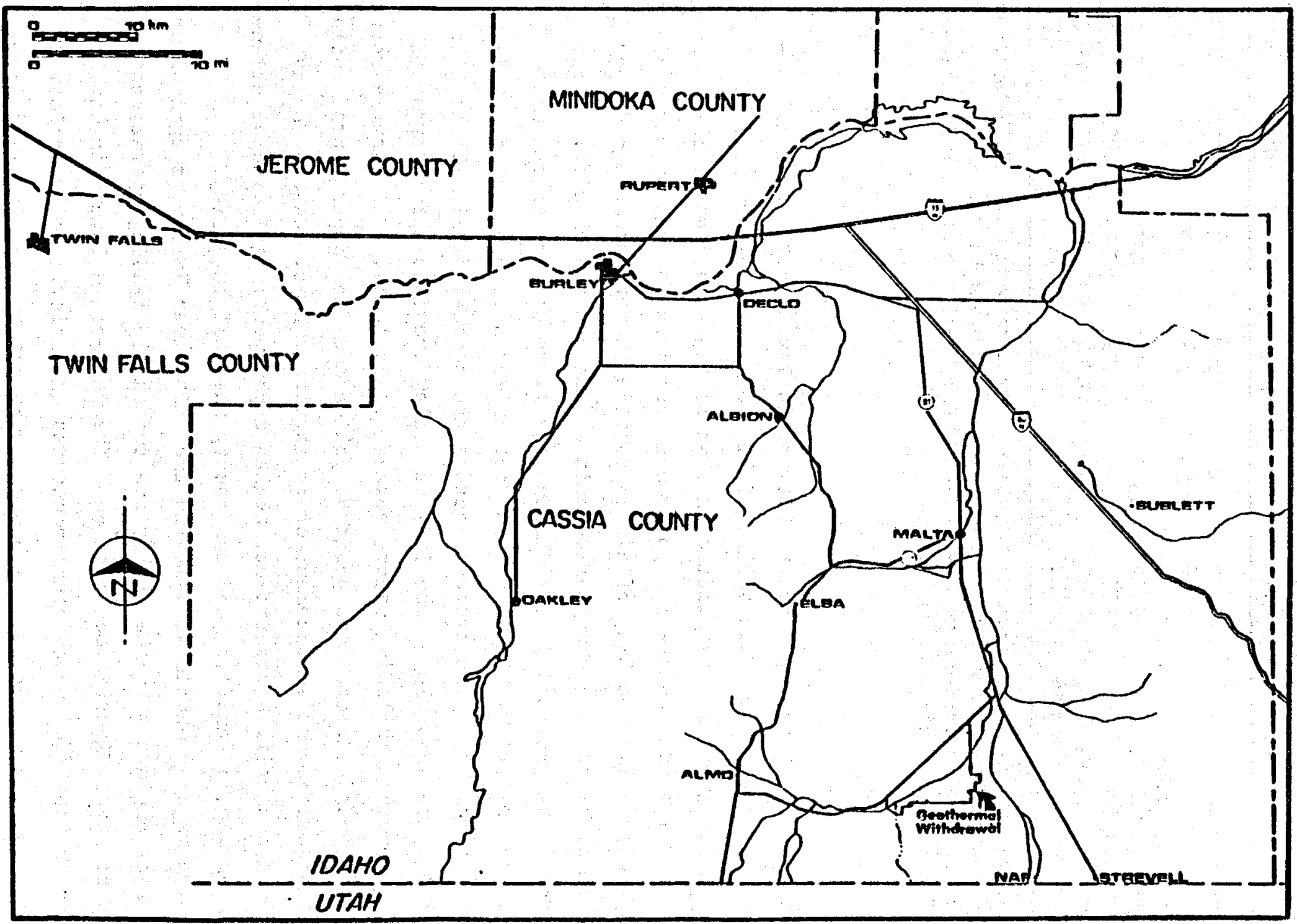

Fig. 2.9. Map of Cassia County, showing geothermal withdrawal area and nearby towns. Source: Idaho National Engineering Laboratory, Environmental Report, Raft River Thermal Loop Facility, TREE-1144, 1977. 
Table 2.12. Cassia County labor force and population statistics, 1970-1975

\begin{tabular}{lrrrrrr}
\hline & 1970 & 1971 & 1972 & 1973 & 1974 & 1975 \\
\hline $\begin{array}{l}\text { Civilian labor force } \\
\text { Percent of labor force }\end{array}$ & 7,389 & 7,528 & 8,006 & 8,311 & 8,607 & 8,233 \\
unemployed, unadjusted & 4.8 & 6.2 & 6.8 & 5.3 & 4.3 & 6.2 \\
Total employment & & & & & & \\
Agricultural employment" & 7,032 & 7,059 & 7,454 & 7,872 & 8,236 & 7,720 \\
Total estimated population & 1,798 & 1,850 & 1,659 & 1,741 & 1,800 & 1,740 \\
Percent of population employed & 17,017 & 17,400 & 17,500 & 18,000 & 18,400 & 18,700 \\
\hline
\end{tabular}

'Extracted from Civilian Labor Force Report, Cassia County for the years 1970-1975. These reports are available through the Idaho State Department of Employment, Bureau of Research and Analysis.

${ }^{b}$ Taken from the annual reports for the years 1973, 1974, and 1975 of the Bureau of Vital Statistics, Idaho Department of Health and Welfare.

small alrport is operated by the C1ty of Burley, but the nearest commercial airport is in Twin Falls, $60 \mathrm{~km}$ (36 miles) west of Burley.

Public services are limited in most of the Raft River Valley. The City of Malta has a part-time policeman, but does not supply water or sewage disposal. The City of Albion supplies water and sewage disposal and the services of a combination maintenance man and sheriff. Fire protection is provided by the BIM and the 14 volunteers of the Raft River Fire District. The Fire District in Malta also operates a DOEdonated ambulance. The nearest doctors and medical facilities to Albion and Malta are in Burley. The City of Burley provides a full array of public services including water, sewage, electricity, a library, airport, cemetery, parks, recreation program, pollce and flre departments, bullding Inspection, and enforcement of zoning ordinances. Cassla County operates a sheriff's department, health department, agricultural extension service, a landfill, and the county hospital in Burley.

The major economic activity in the Raft River Valley is agriculture. The major employers in the valley are two cattle feeding operations and the Raft River Electric Cooperative. The largest employers in Cassia County are the food processing industrles in Burley. While employinent in the county has kept pace with population growth, the increased proportion of the population within the labor force has resulted in Increased 
unemployment (Table 2.12). The 1975 unemployment rate was only slightly above the national average.

Vacast housing is essentially unavailable in the Raft River and Albion valleys, and land is seldom marketed in small parcels. Fewer than ten rental units are avallable in Albion and Malta in addition to avallable units in two motels in Malta. Spaces are available in small trailer parks in Malte and Albion. The Raft River Electric Co-op has subdivided part of a 30-ha (75-acre) plot near Malte to provide home sites for their employees.

Malta is the main educational center of the valley, wh almost 200 students in both the elementary and high schools. Elementary schools are a'so found in Albion (37 students) and Almo ( 9 students).

In February 1977, the ettendees at a meeting of the Raft River Electric Co-op were asked to fill out a questionnalre concerning geothermal development in the valley. The respondents indicated a desire for 8 level of economic development which would keep young people in the valley, and make possible improved services. On the other hand, they wanted to retain the rural character of the valley with its social closeness and neighborliness, clean alr and water, low population density, and minimal goverment. There was a strong desire expressed for control of the rate and nature of development by the citizens of the valley. The questionnaire and a tabulation of results are contained in the Enviromental Report. 3

\subsection{HISTORIC AND ARCHAEOLOGIC SITES AND NATURAL IANDMARKS}

\subsubsection{Historic sites}

The Raft River Valley was an emlgrant crossroads during western expansion. The Oregon Trall crossed the Raft RIver and split into two sections, one leading northwest to the oregon territory and the other to California via Salt lake City. The two sites within southern Cassia County which are currently listed on the National Register of Eistoric Places ${ }^{34}$ are connected with this westward migration (Fig. 2.10). The City of Rocks, now a state park located about $30 \mathrm{~km}$ (18 miles) from the withdrawal area, was one of the popular landmarks along the route to 


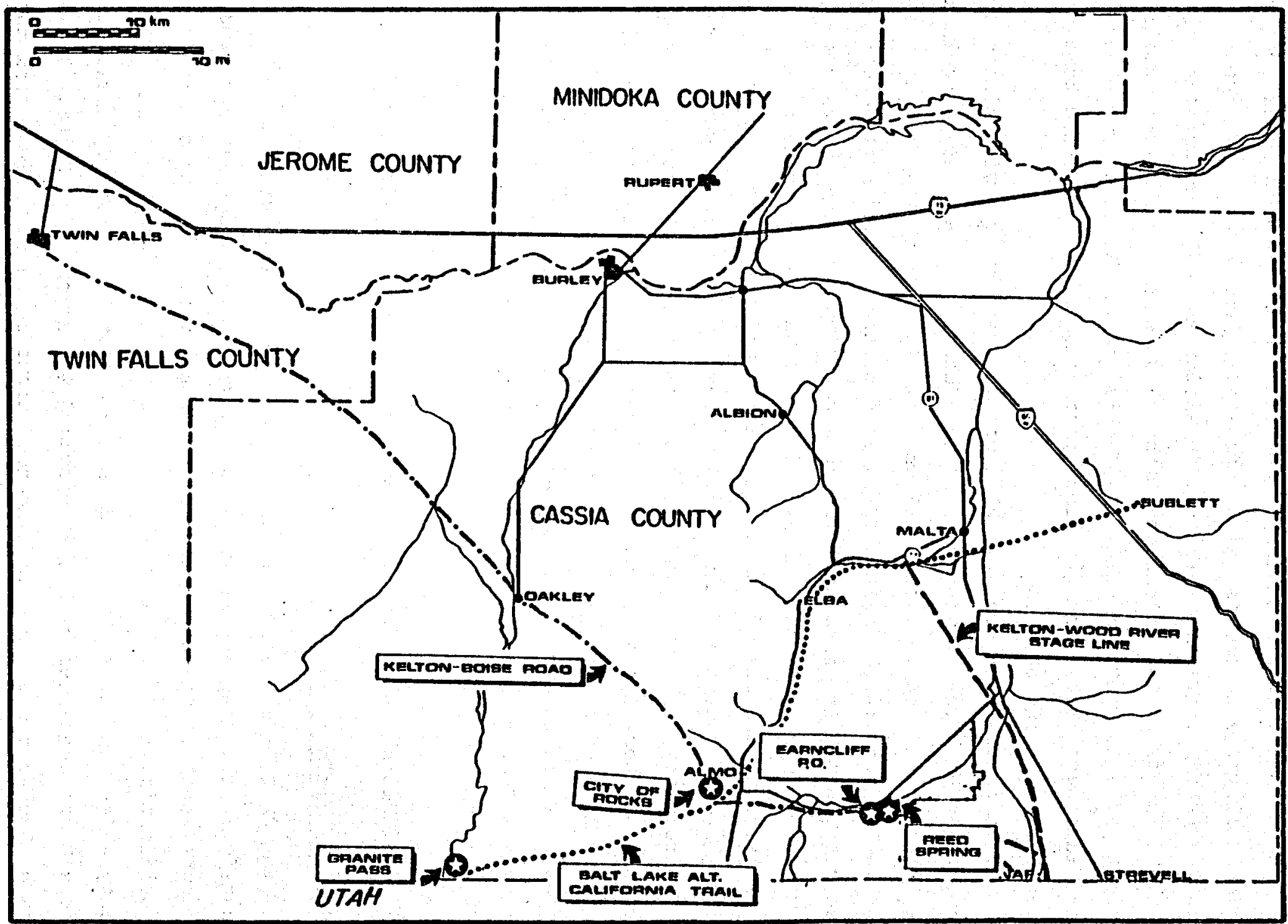

F1g. 2.10. Historic sites in Cassia County. Source: Idaho National Englneering Laboratory, Environmental Report, Raft River Thermal Loop Facility, TREE-1144, 1977. 
California from the Oregon Trail. The well-protected valley, with Its great variety of soft granite formations, was a camp site for thousands of emigrants, many of whom carved their names on the rock formations. Granite Pass, the other historlc site, approximately $55 \mathrm{~km}$ (35 miles) from the withdrawal area, was an important pass along the Californis cut off from the oregon Tra1l. The historic site consists of an unimproved road and a section of the original California Tratl.

In addition to the Californis Trail, there are traces of two other emigrant trafls through the Raft RIver Valley: the Kelton-Wood River Stage Line and the Relton-Boise Road (FIg. 2.10). Neither trall passes through the withdrawal area. The BIM also recognizes two other sites of historic significance in the Raft River Valley: Reed Spring, a campground at a large spring along the Californie Trail, and the Earncliff Post Office, a stagecoach station on the Kelton-Boise Road (FIg. 2.10).3 Both sites are located just west of the withdrawal area. Neither site is currently listed on or proposed for the National Regieter of Bistoric Places. 34

\subsubsection{Archaeologic sites}

A survey to determine the existence of archaeologic resources in the Raft River Valley was undertaken by the Department of Anthropology at Idaho State UnIversity. ${ }^{3}$ Since the Raft River would have been attractive to early aboriginal Inhabitants of the region, survey efforts were concentrated along the river and Its adjacent floodplain. The study consisted of a surface examination of an 11-km (7-mile) stretch along the river from The Narrows almost to Route 81. Seven sites with good archaeologic potential were found within the withdrawal area. ${ }^{3}$ None of the seven sites is within the area proposed for construction of the thermal loop facility; the closest ofte is $0.8 \mathrm{~km}(0.5 \mathrm{mlle})$ away, and the rest are at least $3 \mathrm{~km}$ ( 2 miles) from the proposed construction area. To protect the 61tes, the exact locations may not be disclosed to the public. However, they are included in a report avallable to individuals with the proper credentials at the Idaho National Engineering Laboratory offices in Idaho Falls. 


\subsubsection{Natural landmarks}

The proposed City of Rocks State Park is the orly site in the Raft RIver region that is currently isted on the National Registry of Natural Iandmarks. 35 
REFERENCES FOR SECTION 2

1. P. I. Williams et al., "Geology and Geophysics of the Southern Raft River Valley Geothermal Area, Idaho; D.S.A.," paper presented at the 2nd United Nations Symposium on the Development and Dse of Geothermal Resources, San Francisco, Cal1f., May 20-29, 1975.

2. R. R. Compton, "Geologic maps of the Yost Quadrangle, Box Elder County, Utah and Cassia County, Idaho," Miscellaneous Geologic Map Investigations Map I-672, D.S. Geological Survey, Washington, D.C., 1972.

3. Idaho National Engineering Laboratory, Enviromental Report, Raft River Thermal Loop Facility, TREE-1144, 1977.

4. S. T. Algermissen, "Seismic Risk Map of the United States," In United States Earthquakes, U.S. Dept. of Comerce, U.S. Goverment Printing Office, Washington, D.C., 1968.

5. S. T. Algermissen and D. M. Perkins, "A Probabilistic Estimate of Maximum Acceleration in Rock in the Contiguous United Stetes," U.S. Geological Survey Open File Report 76-416, 1976.

6. J. I. Coffman and C. A. von Hake, Eds., Earthquake Eistory of the United States, National Oceanic and Atmospheric Administration, U.S. Dept. of Commerce, U.S. Government PrInting Office, Washington, D.C., 1973.

7. D. B. Slemons, A. E. Jones, and J. I. Glolett, "Catalogue of Nevada Earthqquakes, 1852-1960," Bull. Seismol. Soc. Am., 55(2) (1965).

8. J. E. Zumberge and C. A. Nelson, EZlements of Geology, 3rd ed., John W1ley, New York, 1972.

9. J. L. Renner, D. E. White, and D. L. Wllliams, "Hydrothermal Convection Systems," In Assessment of Geothermal Resources of the United States - 1975, U.S. Geological Survey C1rcular 726, Arlington, Va., 1975. 
10. Idaho National Engineering Laboratory, Idaho Geothermal Development Projects Annual Report for 1976, Idaho Falls, Idaho.

11. E. H. Walker et al., The Raft River Basin, Idaho-Utah, as of 1966: A Reappraisal of the Water Resources and Effects of Groundwater Development, Water Information Bulletin No. 19, Idaho Department of Water Administration, 1970.

12. U.S. Geological Survey, Surface Water Records, Raft RIver Basin, Raft River at Peterson Ranch (1307800), near BrIdge, Idaho.

13. U.S. Bureau of Land Management, Unit Resource Analysis, Cotterell Planning Unit, Burley District Office.

14. State of Idaho, Water Quality Standards and Wastewater Treatment Requirements, Idaho Department of Environmental and Community Services, 1973.

15. M. J. Mundorff and H. G. Sisco, Groundwater in the Raft River Basin, Idaho, with Special Reference to Irrigation Use, 1956-1860, U.S. Geological Survey Water Supply Paper 1619-CC, 1963.

16. R. L. Nace et al., Water Resources of the Raft River Basin, IdahoUtah, U.S. Geological Survey Water Supply Paper 1587, 1961.

17. C. R. Hosler, "Low Level Inversion Frequency in the Contiguous United States," Mon. Weather Rev. 89:319-339 (1961).

18. Environmental Studies Laboratory, University of Utah Research Institute, Baseline Environmental Studies in the Raft River Valley 1976 Progress Report, 1977.

19. U.S. Envirommental Protection Agency, Effects of Noise on WiZalife and Other Animals, Dec. 31, 1971.

20. R. R. Illingworth, "Factors Contributing to Annoyance by Geothermal Steam Well Venting Nolse at the Geysers," In Proc. Geothermal Environmental Seminam 1976, November 1976.

21. J. R. Gustafson, Vertebrate Stmucture of a Sagebmush Commuity, Washoe County, Nevada, Ph.D Thesis, University of Nevada, Reno, 1974. 
22. R. W. Fautin, "Blotic Communities of the Northern Desert Shrub Blome in Western Utah," EcoZ. Monogr. 16(4):252-310 (1946).

23. U.S. Fish and Wildlife Service, Biological Values in the Raft River Valley Geothermal Lease Area, Boise, Idaho, 1976.

24. S. Findholt, Environmental Impact of Geothermal Development in the Raft River Valiey, Idaho Stete University, Pocatello, Idaho, 1976. Unpublished report on file, Idaho Natlonal Englneering Laboratory, Idaho FeIls, Idaho.

25. R. I. Speth, A Density and Neutron Activation Analysis Study of the Aquatic Invertebrates in the Raft River near the Geothemal Site, unpublished report on file, Idaho National Engineering Laboratory, Idaho FaIls, Idaho, 1976.

26. R. Clark, Aquatic Flora of the Raft Fiver, unpublished report on file, Idaho National Engineering Laboratory, Idaho Falls, Idaho, 1977.

27. H. B. N. Hynes, The Ecology of Ruming Waters, Untversity of Toronto Press, Toronto, Canada, 1970.

28. J. W. Elwood, S. G. Hildebrand, and J. J. Beauchamp, "Contribut1on of Gut Contents to the Concentration and Body Burden of Elements In Tipula spp. from a Spring-Fed Stream," J. Fish. Res. Board Can. $33: 1930-1938$ (1976).

29. U.S. Department of the Interior, "Endangered and Threatened Wildife and Plants," Fed. Regist. 42(135) (1977).

30. D.S. Department of the Interior, "Determination of Certain Bald Eagle Populations as Endangered or Threatened," Fed. Regist. 43(31) (1978).

31. U.S. Department of the Interfor, "Threatened or Endangered Fauna or Flora, Review of Status of Vascular Plants and Determination of Cr1t1cal Eab1tat," Fed. Regist. 40(127) (1975). 
32. J. A. Goodnight, Conmunity Impact Assesement of a Diversified Geothermal Energy Project Proposed for the Raft River Valley, Idaho, Battelle Memorial Institute, Pacific Northwest Division, Seattle, Wash., 1977 .

33. S. G. Spencer (Idaho National Engineering Laboratory), personal communication, Alig. 8, 1977.

34. U.S. Department of the Interior, Advisory Council on Elstoric Preservation, National Park Service, "National Register of Eistoric Places," Fed. Regist. 42(21):6198-6362 (1977).

35. U.S. Department of the Interior, National Park Service, "National Reg1stry of Natural Landmarks," Fed. Regist. 38(171):23982-23985 (1973), 39(112):20405-20406 (1974), and 40(87):19501-19508 (1975). 


\section{POTENTIAI ENVIRONMENTAI IMPACTS}

A discussion of the potential impacts from the development and operation stages of the proposed project follows. The categories of potential impacts are those on the physical environment, including geology, water quality, air quality, land use, and water use; impacts on the biologic environment; socioeconomic effects; effects on historical and archaeological resources; and impacts from accidents. These impacts are basically the same as those identified in a previous environmental assessment (DOE/EA-0008) for the originally planned thermal test 10op facility. The only additions or changes relate to the turbine-generator and its ancillary installations.

\subsection{TMPACTS OF DEVELOPMENT}

\subsubsection{Geological impacts}

During field development and plant construct1on, geological impacts will be Insigaiflcant. There will be no land subsidence, landslides, or induced sefsmicity. In addition to the four presently existing wells, another three wells are planned. As these wells are completed they will be shut-in unt11 test equipment such as heat exchangers is operable. No fluid w11l be produced or injected during fleld development except during brlef flow-testing periods.

\subsubsection{Impacts on water quality}

Potentially harmful drilling, waste, and geothermal flulds will be contained in mud and reserve pits, and contalnment of surface runoff of fluids w1ll be provided by the drainage of well sites toward the pits. The applicant will adhere to adequate drilling practices, such as proper casing and cementing (Sect. 1.2.1), which w111 prevent contamination of freshwater aquifers with geothermal fluids. However, the possibility of leakage to groundwater aquifers from deeper zones (Sect. 2.2.2), and consequent groundwater contamination, cannot be positively ruled out during drilling and injection. 
There is potential for groundwater contamination during flow-testing, but It will be minimal. The reserve pits will be unlined, so that the disposal of flow-test fluids will be by seepage as well as by evaporation. While there have been no percolation tests for the solls beneath the well sites, it is possible that seepage may equal or exceed the volume of disposal by evaporation. The permeablilty of soils is generally moderate (Table 2.3) and the reserve pits w11l be excavated below the zone of lime accumulation, destroying the only relatively impermeable zone within the soll profile.

Nevertheless, the total volume of flow-test fluld will be small, and the chemical composition of the fluid is not expected to be substantially different from that of shallow groundwater. One well was flowtested for four days at a maximum rate of 5511 ters/sec $(870 \mathrm{gpm})$. Total production would be $792 \mathrm{~m}^{3}(0.56$ acre-ft) if the maximum flow rate were sustained. Perhaps half of this volume will reach the water table, assuming that evaporation and seepage rates are equal. Total dissolved solids (IDS) in the geothermal fluid range from 1267 to $4130 \mathrm{mg} /$ iter (Table 2.4), and the fluoride content is high ( 4.6 to $8.3 \mathrm{mg} /$ liter). Irrigation wells in the vicinity have an order of magnitude less fluoride and approximately $1000 \mathrm{mg} / 11$ ter TDS. Eventual mixing with groundwater will dilute the concentration of contaminants to an insignificant level.

Few governmental agencies require liners for reserve pits. The Idaho Dept. of Water Resources. (IDWR) has adopted a flexible policy in this regard. If the production fluid does not differ substantially in chemical quality from the shallow groundwater of the region, if the flow test is of limited duration, or if the area is remote from population centers, a liner w1ll not be required. The IDWR issued a drilling permit for the Raft River flow test loop. A liner was not listed as a required item in the terms of the permit. 1

The chemical character of both irrigation wells and geothermal wells is quite variable. Some of the geothermal wells (RRGE-I and -2) have a lower total dissolved solids content than the average for irrigation wells in the profect area; one geothermal well (RRGE-3) has a considerably higher TDS than the Irrigation wells (Tables 2.4 and 2.6). 
Certain lons such as fluoride have a higher concentration in all measured geothermal wells than the average for irrigation wells. Other constitutents such as heavy metals have not been measured in any of the wells. The concentration of TDS and specific measured lons is higher In all measured geothermal wells than in the Raft River (Table 2.5). Concentrations of contaminants in injection water are unknown at this time; however, due to concentration by evaporation in reserve pits and addition of cooling tower blowdown and exchange lons, they are expected to be higher than those in the geothermal water. Therefore, although some of the geothermal water appears to be sultable for Irrigation, some of it is not and none of it can be disposed of in the Raft River. This and subsequent sections will describe the measures which have been and w111 be taken to protect the water resources of the Raft River Valley.

The construction required in the burying of pipelines beneath the Raft River (Sect. 1.2.1) presents a mintmal hazard to surface-water quality. Increased erosion, sedimentation, and mineralization could aggravate the present condition of siltation and the high suspended and dissolved solids load in the river (Sect. 2.2.1). Any disturbance of the streambed will be clesred with the Idaho Dept. of Water Resources prior to construction. All pipelines will cross beneath the Raft River at the same site and only a few days will be required for construction, resulting in short duration of increased turbidity.

The small septlc tank/evapotranspiration field system for santeary waste disposal (Sect. 1.2.1) is not expected to seriously affect groundwater quality. The system will be $10 \mathrm{cated}$ at least $600 \mathrm{~m}$ (2000 ft) from the nearest well [excluding the $165-\mathrm{m}(540-\mathrm{ft})$ deep BLM hot well and the thermal loop facility domestic well], and groundwater movement in the basin is slow. 2

\subsubsection{Impacts on alr quality}

Air quality impacts during construction and development of the proposed project could result from dust, from emissions from drilling and construction equipment, and from release of noncondensable gases 
during drilling and well-testing. Exhaust emissions from drilling and construction machinery will include $\mathrm{SO}_{2}, \mathrm{NO}_{\mathrm{x}}, \mathrm{CO}$, hydrocarbons, and particulates. These releases will be minor, short-term, and should be readily dispersed. Exhaust emissions from the proposed project should not constitute a significant increment to the present low amblent concentrations of these pollutants in the Raft River Valley (Table 2.10).

A maximum of 44.5 ha (111 acres) of land will be disturbed in connection with construction of additional dr1ll pads, access roads, pipelines, and the pllot plant facility itself (Sect. 3.1.5). Dust will be generated as a result of these activities. Baseline studies have shown that alrborne dust levels are variable in the valley but are generally below the U.S. secondary amblent standard of $60 \mu \mathrm{g} / \mathrm{m}^{3}$. (Table 2.8). Occasionally, during high winds, ambient dust levels exceed the short term ambient standards. A major source of the present dust is probably cleared and cultivated fields. It is not expected that dust generated from land to be cleared during construction and development of the proposed pilot plant will add significantly to present dust levels in the valley. However, construction areas will be graveled or sprinkled to control dust.

Noncondensable geothermal gases will be released during drilling and well-testing. Gases will be released to the atmosphere from the water/steam separator at the well (when one is used) and from the reserve pit. Maintenance of sufficient pressure within the well to protect against blowouts should result in acceptably low levels of gaseous emissions during drilling.

Well-testing will result in direct release of steam and noncondensable gases for approximately' ten days per well. Nitrogen and carbon dioxide are the major noncondensable gases present in the fluids at Raft RIver. ${ }^{3}$ Hydrogen sulfide is a noncondensable gas that is often of some concern because 1ts characteristic unpleasant odor is detectable at low ambient concentrations (30 ppb). The concentration of $\mathrm{H}_{2} \mathrm{~S}$ in geothermal fluid at Raft River is $0.33 \mathrm{ppm}$, which is very $10 \mathrm{w} .^{3}$ Amblent concentrations of $\mathrm{H}_{2} \mathrm{~S}$ measured within a few hundred meters of the RRGE- 1 well when it was flowing were less than $20 \mathrm{ppb}$, below the odor threshold (Table 2.10). 
Concentrations of anonia in the goethermal fluid are also quite low, less than $10 \mathrm{ppm}^{3}$ There is no methane in the fluid. 4 Mercury was detected as e trace at $0.0039 \mathrm{ppb}^{3}$ Because of the very low concentrations of noncondensable gases of enviromental concern, the short-term release of noncondensable gases during well-testing should have no effect on air quality in the Raft River Valley.

\subsubsection{Ecological 1mpacts}

\subsubsection{Terrestrial impacts}

Activities related to development and construction of the proposed project will disturb a total of 44.5 he (111 acres) of land (see Sect. 3.1.5). The type of vegetation that will be removed from this land (predominantly big sagebrush and greasewood) is abundant in the valley and over a large area of the western United States. Most of the small animals that will be lost due to habitat destruction are abundant and widespread in similar areas in the valley. Their loss will not constitute a significant impact on the populations of these animals In the Raft River Valley. None of the land in the big game and game bird habitat on the eastern slopes of the Jim Sage Mountains will be disturbed. The U.S. Fish and WIIdlife Service (USFWS) has recomended that a $50-m(160-f t)$ buffer zone be maintained on each side of a stream (Appendix A): This habitet is important to wildilfe for food, cover, and water. Although it may be necessary to disturb some vegetation along the river to construct geothermal IInes connecting wells on one side of the river to the pilot plant on the other, no wells will be drilled within $50 \mathrm{~m}$ of the river. The construction of any geothermal IInes across the river w111 be coordinated with the USFWS to ensure minimal disturbance of wildife habitat.

The Raft River Valley is good raptor habitat (Sect. 2.5.1). Since the amount of land to be alsturbed during development and construction represents a small fraction of the raptor's hunting habltat, there should be no adverse effect on the raptors from reduction in prey. However, construction and drilling activities could be a potential source 
of disturbance to nesting raptors in the withdrawal ares. Raptors are probably more likely to be sensitive to the human presence associated with these activities than to the noise generated by them.

The ferruginous hawk is of special concern, since this spectes is very sensitive to human disturbance during the early part of nesting. Minimal disturbance near the nest site will cause these hawks to abandon the nest during both nest-building and Incubation of the eggs. 6 Once the young are hatched there is less likelihood of abandonment by the adults. 6 Most ferruginous hawk nests occur outside the withdrawal area and thus should not be affected by the proposed project. 3 However, one nest was located (no longer existing) along the river in the southern part of the withdrawal area. ${ }^{3}$ The USFWS has recommended (Appendix A) that a buffer zone of $0.8-\mathrm{km}(0.5-\mathrm{mlle})$ radius be established around any ferruginous hawk nest; in this buffer zone no surface disturbance would be allowed. The USFWS has also recomended that an additional 0.8-km (0.5-mile) radius be established in which no disturbance, including surveys or drilling, will be allowed from March 1 and July 15 (Appendix A). This perfod extends from the time during which adults first arrive at the nest through the period that the young fledglings spend one to two weeks in the vicinity of the nest. 5 . The USFWS recommendations will be followed.

Development activities should not affect any wintering bald eagles that use the Raft River Valley. There are no known roosts or large concentrations of bald eagles near the withdrawal area. However, if any bald eagle roosts are discovered in the course of development activities, no activity will be allowed within a 1-km (0.6-mile) radius of the roost during the perlod when the eagles are present (December through February). Because the withdrawal area is located at least $2.5 \mathrm{~km}$ (1.5 miles) from the sage grouse strutting grounds, development-related activities should not disturb the grouse.

There should be no significant impact on vegetation from dust generated during construction of the proposed project (Sect. 3.1.3). The small quantities of noncondensable gases released during welltesting (Sect. 3.1.3) should not affect vegetation around the drill sites. 


\subsubsection{Aquatic impacts}

No adverse effects on aquaric ecology are expected to result from the well drilling required for field development because none of the drilling sites are near the river and no materials will be discharged in the river. The extent to which aquatic biota in the Raft River are protected from adverse effects during development will largely be a function of care taken during construction of pipelines buried beneeth the Raft River. The river is already heavily silted, with a high dissolved and suspended solids load. Increased erosion and sedimentation would further reduce the avallable habitat for flsh, invertebrates, and macrophytes. Direct destruction of strean bottom habitat will be unavoidable during the burying of pipeline, but limited in extent. In most of the river in the project area, the stream bottom provides poor habltat for equatic blota. Disturbance of the remaining adequate habitat, particularly riffle areas, will be particularly avolded. There will be only one crossing site, and the turbidity resulting from pipeline construction should last only a few days.

\section{1 .5 Impacts on land use}

\subsubsection{Clearing of land at the site}

Construction of the p1lot plant will require the clearing of approximately $4 \mathrm{ha}$ ( 10 acres) for the plent and assoclated facilities, 16 ha ( 4.0 acres) for an evaporation pond, 0.8 ha ( 2 acres) for each well slte, and 0.2 ha ( 0.5 acres) per well for access roads. Although the pipeline will be laid in trenches which are only wide enough to essemble the pipe, an area approximately $6 \mathrm{~m}$ (20 ft) wide will be disturbed during pipeline construction. If the plpelines average $2 \mathrm{~km}$ ( 1.24 miles) in length, the total area disturbed will be approximately 8 ha (2l acres). Thus, the total area disturbed by drilling and construction (including the four wells already completed) w11l be approximately 36 ha (90 acres).

The vegetation cleared will be elther natural shrub vegetation or irrigated cropland. The pilot plant, evaporation ponds, and most of 
the wells will not be located on Irrigated cropland. The greatest impact on irrigated cropland w11l arise from the construction of well site roads. Most pipeline construction will take place after the growing season and will follow acquired rights-of-way for road construction. Grazing intensity on natural shrub vegetation averages approximately 4 ha (10 acres) per animal unit month (ADM). The loss of vegetation due to construction of this project represents a loss of approximately 10 AUM. Ponds and drill pads will be fenced to protect 1ivestock.

All but 8 ha (20 acres) of this land will be restored to its original use after construction. Irrigated cropland will be returned to cultivation. Public land will be seeded with elther crested wheatgrass or sagebrush depending on the outcome of discussions between the Bureau of Land Management and the U.S. Fish and Wildilfe Service. Crested wheatgrass can support livestock grazing Intensities as high as 0.8 ha ( 2 acres) per AUM. Sagebrush supplies habltat for pronghorned antelope and other wildlife species. Private land owners will probably prefer crested wheatgrass.

As indicated in Fig. 2.5, the only structure within the 100-year floodplain will be the pipeline. This structure will not lead to further development of the floodplain, will not lead to endangerment of hrman health, safety, welfare or property, and does not significantly affect natural and beneficial values served by the floodplain. Therefore, it can not be construed to be in violation of Executive Order 11988 Floodplain Management.

\subsubsection{Impacts of noise}

During the construction period nolse will be produced by the construction activities themselves and by the drilling and testing of new wells. The major source of nolse associated with construction is the operation of heavy equipment which produces sound levels in the range of 70 to $100 \mathrm{dBA}$ at a distance of $15 \mathrm{~m}$ (50 ft) from the source. Measurements of nolse during well drilling with mud include levels of $90 \mathrm{dBA}$. at $15 \mathrm{~m}(50 \mathrm{ft})$ and 68 to $71 \mathrm{dBA}$ at $30 \mathrm{~m}(100 \mathrm{ft})$. At various stages during drilling and following completion of drilling, the wells are 
allowed to flow through a flasher/separator to the atmosphere and reserve pit. Noise levels of less than 80 dBA were measured at $15 \mathrm{~m}$ (50 ft) from an open discharge line.

Five occupied residences exist on private land within the withdrawal area. One is approximately $0.5 \mathrm{~km}$ ( 0.3 miles) from the most likely pilot plant site. Estimates for attenuation at this distance and at $1 \mathrm{~km}$ ( 0.6 mile) are presented in Table 3.1. These estimates do not include effects of intervening objects or atmospheric conditions, but the low vegetation and even topography of the area would add little to nose attenuation. Construction activities will occur during the day over a perioi of almost two years. Drilling will continue 24 hours a day for a period of from three weeks to two months per well. Well venting will occur at irregular intervals for periods of several hours.

Table 3. 1. Predicted noise impact of construction activities (dBA)

\begin{tabular}{lccc}
\hline Activity & $\begin{array}{c}15 \mathrm{~m}(50 \mathrm{ft}) \\
\text { from activity }\end{array}$ & $\begin{array}{c}0.5 \mathrm{~km}(0.3 \text { mile) } \\
\text { from activity }\end{array}$ & $\begin{array}{c}1 \mathrm{~km}(0.6 \text { mile) } \\
\text { from activity }\end{array}$ \\
\hline Construction & $70-100$ & $40-70$ & $34-64$ \\
Drilling & 90 & 60 & 54 \\
Well venting & 80 & 60 & 44 \\
\hline
\end{tabular}

- The nearest critical receptor for plant construction noise is a residence which lies within $0.5 \mathrm{~km}$ of the most likely site.

While these nolse levels are routinely accepted by residents of citles, they may be obtrusive in the rural environment of this project. The very low frequency nolse produced by well-testing is particularly obtrusive because it is unusual and is not greatly diminished by shutting doors and windows. However, nolse levels are generally not expected to exceed Environmental Protection Agency (EPA) or Housing and Urban Development (HUD) guldelines because most construction and well drilling and venting are carried out at least $0.5 \mathrm{~km}(0.3 \mathrm{mlle})$ from residences (one occupied residence is within $0.5 \mathrm{~km}$ of a well site). Mitigation of noise effects on animals is provided by the buffer zones 
around important habitat (Sect. 3.1.4). Construction personnel w111 be protected from excessive noise according to OSHA and DOE standard practice.

\subsubsection{Impacts on water use}

It is possible that surface and groundwater resources (Sects. 2.2.1 and 2.2.2) will become increasingly scarce in the basin because of heavy agricultural water use (Sect. 2.7), regardless of the pllot plant development. Under current moratorium restrictions it is hoped that the water level within the basin will reach equilibrium with current pumping levels.

Miscellaneous groundwater uses, such as sanitary and fire protection systems and well drilling, will require the withdrawal of up to $4.9 \times 10^{4}$ liters/day $\left(1.3 \times 10^{4} \mathrm{gpd}\right)$ from one pumped well. On an annual basis, this use of up to $1.8 \times 10^{4} \mathrm{~m}^{3} /$ year $(14$ acre-ft/year) will represent less than $0.5 \%$ of estimated grundwater use in the project area (Sect. 2.7). It has been estimated that pumping at more than 20 times this rate for almost three years would lower the water table less than $0.3 \mathrm{~m}(1 \mathrm{ft})$ at a distance of $0.6 \mathrm{~km}(2000 \mathrm{ft}) .{ }^{7}$ The projected pumping of groundwater during the project is not expected to have an adverse effect on groundwater resources. Water required during drilling will come from domestic and/or geothermal wells. About $1.1 \times 10^{7}$ 1iters $\left(3 \times 10^{6} \mathrm{gal}\right)$ will be required for each of three new wells, for a total of $3.3 \times 10^{7}$ liters $\left(9 \times 10^{6} \mathrm{gal}\right)$. Less than $4.9 \times 10^{4}$ 1iters/day $\left(1.3 \times 10^{4} \mathrm{gpd}\right)$ will be withdrawn from domestic wells. These withdrawals will not conflict with existing approprlated water rights in the valley.

Because of the apparent connection between the geothermal reservoir and shallow groundwater aquifers (Sect. 2.2.2), it is possible that the flow-testing of geothermal wells could lower the water table in some locations. Additionally, flow from the BLM and Crank (hot) wells could be adversely affected. Flow from the BLM, Crank, and groundwater 
wells is appropriated and utilized (Sect. 2.7), and a reduction in the wells' productivity could represent a significant impact. Contamination of groundwater, possible during reinjection, could also affect its use. Groundwater quality is being monitored in wells drilled around the injection wells and in existing irrigation wells.

Beneficial uses of the Raft River are protected according to its Class A designation (Sect. 2.2.1). Although the river in the project area is heavily sedimented and provides a poor fishery (Sects, 2.2.1 and 2.7), further degradation of the river will be minimized by burying the pipelines $1 \mathrm{~m}(3 \mathrm{ft})$ beneath the river at a single crossing site and completing construction within a few days.

\subsubsection{Socioeconomic impacts}

The socioeconomic characteristics of the Raft River Valley may be modified during the construction period by the importation of workers and their families, employment of local residents, and infusion of money into the economy. During the 21 months of construction, an average of 24 workers will be employed, with a maximum work force of 47 . In addition, a drilling crew of 24 workers will be required for six months in 1978.

Consultation between the Southern Idaho Building Trades Counc1l and the Idaho National Engineering Laboratory Indicates that the construction crew can be recruited from within southern Idaho. Those who live in Burley or even as far away as Pocatello and Twin Falls are expected to commute to the site. The experience of the Idaho National Engineering Laboratory suggests that less than one-third of the construction force can be expected to move into the area, and at least $70 \%$ of the nonlocal construction force will not bring their families. Because of the absence of a skilled construction labor force, hiring of Raft River Valley residents is not expected to be significant.

Because no deep-hole drilling firms are based in Idaho, drilling crews must be Imported from other states. Previous crews for the Raft River site have lived as a unit in short-lease apartments or motels in Burley. It is expected that this pattern will be followed in the future. 
The relatively long drilling perlod in 1978 (six months) may lead a few crew nembers to bring their families.

Most nonlocal construction workers are expected to find housing in Burley. The low evallability of housing in the Raft River Valley, the short duration of construction employment, and the absence of urban amenities make it unlikely that many of these workers will settle in the valley. Drilling crews and many of the construction workers will probably utilize Burley's 15 motels. Although apartment availability is low, the housing market in Burley should not be strained by the requirements of the construction force.

Secondary employment produced by the project is expected to reach a maximum of 15 positions. Most of these will be located in Burley. The local pool of unemployed labor is easily adequate to ftll this need.

The project will make few demands on public services and will do little to change the rural character of the valley and its close friendly social climate. On the other hand, it will supply few jobs for valley residents and little revenue, for local govermments.

\subsubsection{Impacts on historical and archaeological resources and natural lendmarks}

There are no historic sites or natural landmarks close enough to the project area to be affected by construction and development of the proposed facility (Sect. 2.9).

None of the seven potential archaeologic sites identified during the survey (Sect. 2.9) w11l be disturbed by construction of the pilot plant facility. If any archaeologic resources are uncovered during excavation for roads or pipelines, the proper authorlties will be contacted and approprlate measures taken to preserve the resources.

\subsection{IMPACTS OF OPERATION}

\subsubsection{Geological impacts}

When the plant begins operation there is a potential for subsidence throughout utilized portions of the well field. According to Atherton 
et al.,$^{8}$ subsidence is considered to be a defintte hazard in Iiquiddominated systems, especially where artesian pressure exists at the wellhead ( 10 to $12 \mathrm{~atm}$, or 150 to $170 \mathrm{psi}$, at Raft RIver). As the reservoir pressure declines, compaction will occur. Even under normal (hydrostatic) pressure conditions, normal compaction of clays, silts, and shales will be accelerated because of the creation of a new drainage path. How much of the reservoir compaction will be translated to the surface as subsidence is not known at this time.

Lofgren 9 has documented land subsidence in the Raft River Valley. He compared 1974 leveling data with elevations established 40 years earlier and came to the conclusion that subsidence is caused by two contributing factors: (1) reglonel tectonic movements [ a maximum of $6.4 \mathrm{~cm}$ (2.5 in.)], and (2) withdrawal of groundwater for irrigetion [a maximum of $80 \mathrm{~cm}(31.5 \mathrm{in.})$ ]. Lofgren was reluctant to define the areal extent of subsidence, but he tentatively suggested that more than $260 \mathrm{~km}^{2}$ (100 sq miles) is involved.

A leveling grid has been established for the purpose of monitoring subsidence around the pilot plant facility. 3 This grid will be releveled semiannually. If any subsidence is detected, a more detalled grid w111 be established in an attempt to determine the cause of such subsidence.

Injection of geothermal flulds into the production reservolr can mitigate, but not entirely eliminate, subsidence. (There is no plan to reinject into the reservoir at the Raft River project, however.) Maximum makeup water requirements for the cooling tower are 17 ilters/sec (264 gpm) for evaporation and 7 11ters $/ \mathrm{sec}(115 \mathrm{gpm})$ for blowdown. Makeup water will be derived entirely from geothermal water. If the use of geothermal water for agricultural experiments continues, this may add significantly to the amount of unreplaced geothermal water. Without agricultural tests, a maximum of $20 \%$ of the geothermal fluid will not be returned to the subsurface. 3

Ideally, Inject1on should take place in the same aquifer as production. Current plans, however, are to inject geothermal flusd at a shallower depth [between 580 and $820 \mathrm{~m}$ (1900 and $2700 \mathrm{ft}$ )] than the production zone, which is between 1400 and $1600 \mathrm{~m}$ (4600 and $5200 \mathrm{ft}$ ). 3 
The rationale is that injection against the wellhead pressure at depth (10 to $12 \mathrm{~atm}$, or 150 to $170 \mathrm{psi}$ ) would be impractical. Injection Into a zone above the production zone will possibly result in forming a pressure cap on the geothermal reservoir. However, injection into a shallower aquifer as a means to mitigate subsidence is a controversial subject. Idaho Nationel Engineering Laboratory belleves that the reduction in pressure gradient between the production and injection zones will reduce the fluid flow from the former to the latter. Lofgren, 10 on the other hand, belleves that injection of fluid into a shallower aquifer amounts to nothing more than a disposal system at best. It is conceivable that hydrofracturing the injection zone could lead to Increased hydraulic communication with the production zone, causing loss of reservolr fluid and possibly increased subsidence. Source terms for calculating subsidence are not avaliable, but the amount of subsidence is not expected to be significant due to the limited scope of the proposed project. Historically, subsidence is only a major import where large quantities of fluid are withdrawn over extended periods of time (example, Pasadena, Texas; San Joaquin Valley, California; Chocolate Bayou O1I Field, Texas). Because actual behavior is undetermined at this time, it will be necessary to monitor for subsidence by means of a close-order land survey. Baseline elevations are already known. 9

Land subsidence will probably have little environmental impact on anything other than the pilot plant itself. The magnitude of subsidence Is expected to be swall because of the limited nature of the proposed project. There should be little or no effect on the Raft RIver. Hence, croplands are not expected to be replaced by wetlands. There are no non-project-related structures along the Raft River to be Impacted by subsidence. Differential settlement cracks may appear in the foundations or walls or pilot plant bulldings, and jolnts between distribution lines and wells may separate. Settlement cracks will probably not be serious. The escape of geothermal fluid, however, is a matter of considerable concern. Since distribution lines settle as the land subsides, whereas the well casing does not, subsidence-induced ruptures between pipelines and wells can be prevented by installing flextble joints. While it may 
not be necessary to install flexible joints inftlally, monitoring for subsidence may indicate the need for retrofitting.

The use of an Intermediate-depth injection aquifer appears to be an adequate disposal locale. It should not interfere with either the geothermal aquifer or the shallower irrigetion aquifers, at least not within a short time frame. Long-term effects will be monitored carefully against contamination of Irrigation aquifers and pressure and/or temperature decline of the geothermal reservoir. Monitor wells are being installed for this purpose. ${ }^{3}$

The possibility of induced selomicity exists. Current plans are to Install injection pumps designed to pump 150 liters/sec (2500 gPm). These pumps will increase the injection fiuld pressure from 8 to 20 atm (120 psi to 300 ps1). ${ }^{3}$ Pump injection, as opposed to gravity injection, is required because of the artesian pressure (2.7 atm, or $40 \mathrm{psi}$ ) and relatively low permeability that exist in the injection aquifer ${ }^{11}$ at a depth of $610 \mathrm{~m}(2000 \mathrm{ft})$. With a wellhead pressure of 20 atm (300 psi) there is a minimal danger of fault activation or hycrofracturing and, thus, Induced selsmictty.

Evans 12 has shown a correlation between selsmicity and fluid injection at Rocky Mountain Arsenal near Denver, Colorado. He also showed that injection by gravity flow significantly reduced seismicity. He concluded, therefore, that high levels of Induced selsmicity are unlikely to occur unless the fluid is injected under high pressure. Wellhead pressures between 34 and 68 atm (500 and 1000 psi) produced significant Induced selsmicity at Rocky Mountain Arsenal.

Although Induced selsmicity might be Instrumentally perceptible at Raft River, it is not likely to cause damage to surface structures. Injection pressure at Rocky Mountain Arsenal was 2 to 10 times greater than that proposed at Raft River, but it created only mild earthquakes and no documented incidences of damage.

Baselines studies show that microselsmiclty ${ }^{3}$ has a low frequency of occurrence in the Raft RIver Valley (Sect. 2.1.2). Therefore, a microseismic monitoring net would be useful in detecting any increased selsmicity related to the production and injection of geothermal fluids. 
A three-point microselsmic system has been installed in the vicinity of the geothermal wells. ${ }^{3}$ This system will soon be expanded. An Increase in the level of selsmicity would suggest that the injection aquifer had been hydrofractured, creating the potential for excursion of fluld into a potable aquifer.

If the level of selsmic activity should Increase above baseline activity, Its relationship to injection pressure w111 be evaluated. If a functional relationship is found, the injection pressure may have to be reduced, or, depending upon the severity, infection wells may have to be capped. If infection wells are shut in, the pilot plant would also be required to shut down until an alternative fluid disposal system is developed.

\section{2 .2 Impacts on water quality}

Barring an accident, such as a blowout, plpeline rupture; system fallure, or reserve pond faflure (Sect. 3.4), operation of the plant is not expected to have adverse effects on surface-water or groundwater quality. Potentially harmful blowdown from the cooling tower w111 be held in impermeable evaporation ponds (plastic liner over a bentonite base) and/or injected, rather than be released to the surface. During injection, the possibility does exist for contamination of groundwater resources if there is interaction between injection zones and shallow groundwater aquifers. Because of the appropriated status of these water resources (Sect. 2.7), such contamination could have a serlous impact. (Blowdown will only be injected if it meets state water ouality standards and will not contaminate upper aquifers. Significant thermal pollution of the Raft River as a result of the passage of geothermal fluids through the buried pipeline is unlikely, because of the insulation around the pipe and the layer of river bottom substrate between the pipe and the river water. Water quality of the Raft River would probably be protected in the unlikely event of contamination of groundwater in the project area because the river recharges groundwater in the area, rather than being fed by groundwater. 


\subsubsection{Impacts on eir quality}

Since all access roads will be paved or oiled and disturbed land will be reseeded, there should be little dust generated after construction and development activities have concluded. The major potential impact on air quality from operation of the plant will result from the cooling tower, which will use geothermal fluid for makeup. Cooling tower emissions will consist of water vapor and noncondensable gases. During normal operations, the only noncondensable gases vented to the atmosphere from the pilot plant will be those contained in the portion of the fluid used for cooling tower makeup. Maximum makeup water requirements (ususily occurring in July) are 17 11ters/sec (264 gpm) for evaporation and 7 11ters/sec ( $115 \mathrm{gpm}$ ) for blowdown. ${ }^{3}$ The only noncondensable gas of concern is $\mathrm{H}_{2} \mathrm{~S}$ (Sect. 3.1.3). Assuming that all of the $\mathrm{H}_{2} \mathrm{~S}$ in the makeup fluid (at a concentration of $0.33 \mathrm{ppm} \mathrm{H}_{2} \mathrm{~S}$ ) will be released, the maximum expected ground-level concentration will be approximately $10 \mathrm{ppb}$. This maximum concentration could be expected to occur $100 \mathrm{~m}$ ( $330 \mathrm{ft}$ ) from the tower during slightly unstable atmospheric conditions (Pasquil stability $C$ ) with a wind speed of $1 \mathrm{~m} / \mathrm{sec}(2.2 \mathrm{mph})$. Since this maximum ground-level concentration of $\mathrm{H}_{2} \mathrm{~S}$ is one-third of the odor threshold ( $30 \mathrm{ppb})$, there should be no impacts on air quality from noncondensable gases from the cooling tower.

Particulates in the form of dissolved solids will be part of the drift from the cooling tower. Total dissolved solid content of the geothermal fluld is approximately $1400 \mathrm{ppm}$, which is lower than the level in irrigation water used on crops in the vicinity of the withdrawal area. 3 Drift eliminators to be installed on the tower will keep drift deposition rates well below levels wh1ch damage the leaves of even sensitive crops. In any case, drift from the planned smallscale mechanical draft tower will fall within a few hundred meters of the tower and should not affect local alr quality or deposit significant amounts of salt on crops. In addition to the natural contaminants, chromium and zinc will be added to the cooling water. Concentrations of these metals will be monitored in soll, vegetation, and wildiffe in order to avoid the possible development of toxic concentrations. 
Because of the semlarid climate, the evaporation of water from the tower and ponds typically w1ll not saturate the air, and there should be no visible plume. Eowever, on cold winter days a plume will in all likelihood be visible from the tower and steam will probably form over the evaporation ponds. These localized plumes should not constitute a significant impact on alr quality or a hazard to local road traffic.

\section{2 .4 Ecological impacts}

\subsubsection{Terrestrial impacts}

Yuch of the land cleared during construction and development of the plant w1ll be revegetated, and therefore it should not be permanently lost as wildife habitat. Noise and human activity in the withdrawal area during operation should be less than that during the construction and development phase and should not adversely affect wildlife. U.S. Fish and Wildife Service recomendations concerning activity in the vicinity of ferruginous hawk nests and sage grouse strutting grounds (Sect. 3.1.4.1) will be followed during the operation of the plant. The short transmission line carrying power from the facility could represent an electrocution hazard to large raptors. Electrocution will be prevented by using tower designs which will serve to prevent contact across conductors by large birds.13,14

The release of noncondensable gases from the cooling tower will be low enough (Sect. 3.2.3) to have no affect on vegetation in the vicinity of the tower. Because the dissolved solids content of the geothermal fluid to be used as cooling tower makeup is relatively low, it is unlikely that vegetation in vicinity of the tower will be affected by salt drift. In any case, drift will fall only within a few hundred meters of the tower (Sect. 3.2.3), and probably less than 20 ha (50 acres) would be affected. The cooling tower should not constitute a significant impact on terrestrial biota.

\subsubsection{2, Aguatic impacts}

Protection of the Raft River from chemical and thermal pollution will prevent impacts on aquatic biota during operation of the plant. 
The water requirements of the project (cooling tower makeup, drilling fluids, fire protection, and sanitary systems) will be satisfied from geothermal and/or domestic wells, rather than by consumption of river water. Therefore, flow of the river will not be reduced during plant operation, unless lowering of the water table in the vicinity of the Raft River causes increased percolation of river water into the ground (Sect. 3.2.2).

\subsubsection{Impscts on land use}

During operation the plant, evaporation ponds, access roads, and wells will occupy 8 ha ( 20 acres) of land. Most of this will be grazing land which is currently in natural vegetation. The land area lost would not be sufficient to support one cow for a year. Some of the wells may be placed on land which is currently cultivated. Because water rather than land is the limiting factor in agricultural production, the lost land could usually be replaced by bringing new land under cultivation. Restored unirrigated land will revert to its original use as livestock grazing land and wildlife habltat. If the land is restored by planting crested wheatgrass, the increased usefulness of the land for grazing from approximately 4 ha ( 10 acres) to 8 ha (20 acres) per animal unit month will compensate for the land lost to the operating plant.

Air pollution from the plant is not expected to affect vegetation or livestock (Sect. 3.2.3).

The presence of geothermal pipelines burled under fields may affect agricultural production. Warming of the soll will increase evaporation and may affect root growth. The magnitude of this effect cannot be predicted, but the area potentially affected is small. Observation of the pipe corridors and the soil warming experiments should elucidate this potential problem.

The nolse level will be reduced from that of the construction perfod. The major source of noise will be the cooling tower. Cooling tower noise will be approximately $80 \mathrm{~dB}$ at $5 \mathrm{~m}(16.5 \mathrm{ft})$ or $50 \mathrm{~dB}$ at $500 \mathrm{ml}(0.3 \mathrm{mlle})$. These levels would not cause health effects or serious aesthetic effects.

Effects of plant operation on visual aesthetics will be reduced from those of the construction period due to revegetation and removal 
of the drilling rigs. Because of the dry climate, the cooling tower plume will typically only be visible during the winter. The cooling towers and other structures will not be tall and will therefore not be conspicuous. The use of reflective metal surfaces will be avoided by painting sheet metal buildings in natural tones.

\subsubsection{Impacts on water use}

It is possible that surface-water and groundwater resources (Sect. 2.2.1 and 2.2.2) will become increasingly scarce in the basin because of heavy agricultural water use (Sect. 2.7), regardless of pilot plant development. Onder current moratorium restrictions, however, it is hoped that the water level within the basin will reach equilibrium with current pumping levels.

Use of groundwater in the project area (Sect. 2.7) could be affected If Interactions between the geothermal reservoir and shallower groundwater aquifers result in a lowered water table and reduced Irrigation well flow during facllity operation. Because of the appropriated status of groundwater in the project area (Sect. 2.7), adverse effects on available groundwater could have a serlous impact. Not all produced geothermal fluids will be available for injection. The use of the fluids for cooling tower makeup is expected to require about $13 \%$ of the production rate. Additional geothermal fluids may be needed for the drilling of wells.. The withdrawal of groundwater from a domestic well for fire protection and sanitary systems is not expected to have a serious effect on water use (Sect. 3.1.6). Effects on water use because of reduction in surface-water or groundwater quality are not expected (Sect. 3.2.2).

Beneficial uses of the Raft River, protected according to its Class A designation (Sect. 2.2.1), are not expected to be affected by facllity operation, unless lowering of the water table in the vicinity of the Raft River causes increased percolation of river water and a resultant lowering of flow. 


\subsubsection{Socioeconomic Impacts}

Although the level of expenditure for the project will be lower for the operation phase than for the construction phase, the socioeconomic effects on the local area during operation way be greater. The operating plant w111 require $a$ work force of 13 for a period of at least five years. Because the supply of trained technicians in the county is not high, it is expected that as many as ten of the operators will come from outside the area. These people and their families will become established members of the community.

It is difficult to predict the distribution of new residents. Malta is the closest town to the project ( $24 \mathrm{~km}$ or $15 \mathrm{miles}$ away), but it offers few social services and is far from the area's shopping center, Burley. Lots are available in Malta on land owned by the Raft River Electric Co-op. Albion offers an intermediate location between the project and Burley, as well as municipal, water and sewage and a pleasant hillside locetion. The small towns of Almo and Elba may attract new residents if housing is avallable. Burley offers a broad range of social services, urban amenities, and a relatively large housing market but requires a 160-km (100-mile) roundtrip commute to the project site. Employees of the Idaho. National Engineering Laboratory may stay in a Malta motel and commute on weekends from Idaho Falls. It is Iikely that the distribution of new population will result in the addition of only a few families to any one commulty.

Secondary employment produced by the operating project will be low, and probably no more than one or two of these new jobs will be in cities other than Burley. The estimated number of school age children from 13 new families is 18 . This is less than the normal variation in the student body of Raft River School.

Plans for disposition of the electrical power produced will not be made until an operator of the plant 15 chosen.

The pllot plant is unlikely to produce significant local economic stimulation in the form of taxes or trade elther from the eventual sale of electricity or from employment changes. The drilling of geothermal wells on private land to supply the plant will be avoided so that rent 
and royalty payments will be low. Itttle land will be required for housing in any one commutty; therefore land prices should not increase significantly. Demand for social services may increase somewhat due to the desires of new residents and the expectations of new revenue for such services from the project. The questionnaire issued to members of the Raft River Electric Co-op suggested that such revenue is forthcoming. However, this profect is not expected to generate significant amounts of new goverment revenue and it is unlikely that the few new residents will overcome the general aversion of older residents to public indebtedness. The electrical generating capacity of the project is small in comparison to the total electrical system demand.

This project w111 not generate the employment expected by some local residents, but it will also not destroy the rural character of the valley or its close, friendly social structure. If the success of this program leads to greatly increased geothermal development for further electrical and nonelectrical uses, then the social and economic costs and benefits could become sigaificant. Valley residents have expressed a desire to be kept informed of plans for geothermal development so that they can exercise some control over its effects. This desire will be honored by DOE.

\subsubsection{Impacts on historical and archaeologic resources and natural landmarks}

There are no historic sites or natural landmarks close enough to the project site to be affected by operation of the pilot plant. Effects on archaeologic resources would occur only during construction and development (Sect. 3.1.8).

\subsection{SITE RESTORATION}

All land cleared around the pllot plant except for the approximately 4 ha (10 acres) needed for the plant itself w1ll be contoured and reseeded. of the land cleared for each drill site, an area approximately $23 \times 30 \mathrm{~m}$ $(75 \times 100 \mathrm{ft})$ w11l be left graveled around the wellhead to provide access 
for maintenance and testing activities. After driliing and completion of each of the wells, all equipment will be removed from the drill site, and the reserve pit will be backfilled unless required for further flow-testing. Reserve pits will not be used as evaporation ponds and will only contain nontoxic drilling mud end cuttings. All disturbed land, excluding that left for access, will be graded, contoured to approximate the netural slope, and reseeded. Upon abandonment, the well will efther be plugged according to State of Idaho requirements or capped for use as a monftoring well. At that time, all land around the wellhead and the access road will be contoured and reseeded as necessary. In specific cases, requests from the Bureau of Land Management (BLM) or private landowners to leave access roads intact would be honored.

It is Iikely that the pilot plant will be turned over to a utility or group of utilities after five years of operation. 15 However, the process system of the plant coulc be dismantled about two to five years after commencement of test operation if all desired test data had been derived by DOE and the utilities were not Interested in the system. In such a case, all facllitles and equipment would be removed. Any material not recyclable would be disposed of at a landfill or as prescribed by state or local requirements. All ponds would be backfilled as soon as they were dry. When all land area, including access roads, had been cleared, it would be graded, contoured, and reseeded. Currently, the BLM generally requires reseeding with crested wheatgrass. Recent requests by the U.S. Fish and Wildiffe Service to reseed to sagebrush for habitat enhancement would be resolved with the BLM, and action would be taken accordingly.

\subsection{ACCIDENTS}

The most Iikely serious accident is an uncontrolled release of geothermal fluids. Release of flulds may occur at the wellhead, in the well bore (blowout), or in pipelines. Blowouts can occur during exploratory drilling, well field development, or during operation of the plant. At the relatively low temperatures and pressures 
encountered in the fluids at Raft River, the potential for blowouts is very low. Blowouts may result in surface cratering; land, water, and atmosphere contamination; excessive noise; geothermal energy waste; and personnel injury. Released fluids could destroy crops and contaminate solls beyond the tolerance of plants within a relatively small area around the blowout.

Casings may rupture during operation in several ways: through subsidence caused by withdrawal of fluids; through seismicity induced by injection; through naturally occurring earthquakes; through landslides; and through corrosion. Induced seismicity is unlikely at the profect site (Sect. 3.2.1), and landsliding is essentially impossible on the valley floor. Some subsidence may occur in the imediate vicinity of production wells. Flextble piping or joints can be used if needed between gathering lines and wells to prevent pipeline rupture due to subsidence. The most likely cause of casing fallure is corrosion. If the casing ruptures in an aquifer zone, groundwater contamination and waste of geothermal energy may occur. If rupture takes place in a relatively impermeable zone, Iittle or no damage to the enviroment or waste of energy will result, but the well casing would have to be repaired.

The most 1ikely mechanism for an uncontrolled release of geothermal fluids will be pipeline rupture. Whereas blowouts and ruptured well casings may be difficult to bring under control, pipelines can be isolated by shutting in the appropriate wells and, if necessary, closing down the plant. A pipeline rupture would result in a surface or underground spill of fluids that could contaminate solls and destroy vegetation in the immediate vicinlty of the spill. However, it is possible to discover and stop the flow of leaks within approximately 10 min. of their occurrence. The envirommental consequences of a sp111 would be minor unless the fluids reached the Raft River. The total discharge of one well would equal $16 \%$ of the minimum average dally flow of the river. A spill of fluids into the river could result in destruction of aquatic blota near the spill and short-term degradation of downstream water quality. Special care w1ll be taken in the construction of all pipelines near the river. 
The only other credible major accident that could occur during operation of the plant would be a fire. Flamable hydrocarbons such as 1sobutane, propane, and pentane are being considered singly or as mixtures for the secondary working fluid. A major rupture could result in loss of the entire 170,000 -Iiter $(45,000-\mathrm{gal})$ working volume before action could be taken ( 13 min at the process circulation rate), but smaller leaks would permit shutdown and dumping of the secondary fluid into underground storage tanks. Routine precautions to be taken in the storage and handing of these materials, including exclusion of Ignition sources from the plant area, should greatly reduce fire hazards. SInce a mercaptan odorant will be added to the working fluid, leaks will be detectable at concentrations of $20 \%$ of the lower flemable limit. Although most plant facilities are located on high ground (terrace deposits), the process heat exchangers will be nearer the river. Since isobutane is heavier than alr, it is more likely to be isolated from the main plant if a gas leak should develop. There will be a fire protection system built at the plant, Including a separate well and storage tank to provide surge capacity for fighting fires. Water can be used to cool the fire in order to limit damage and prevent its spread. Fire fighting equipment and techniques will comply with the standards of the National Fire Protection Association. A major fire could destroy the plant and injure personnel, but would be unlikely to spread beyond the plant.

Leaks of secondary working fluids without fire are unlikely to have serlous environmental effects. Simple saturated hydrocarbons have minimal acute toxiclty to vertebrates and are essentially nontoxic to plants. The D.S. occupational standard for both propane and pentane is a time-weighted average of $1000 \mathrm{ppm}$, and no toxicity is recognized for isobutane. 16 No long-term exposure is anticipated. Asphyxiation due to acute exposure will, under most clrcumstances, be prevented by detection of the mercaptan ocorant and by dispersal. 
REFERENCES FOR SECTION 3

1. R. Folt (Idaho Dept. of Water Resources, Bolse, Idaho), personal communication to W. P. Staub (Oak Ridge National Laboratory), Feb. 1978.

2. E. E. Walker et al., The Raft River Basin, Idaho-Utah, as of 1966: A Reappraisal of the Water Resources and Effects of Groundwater Development, Water Information Bulletin No. 19, Idaho Department of Water Administration, 1970.

3. Idaho National EngIneering Laboratory, Environmental Report, Raft River Thermal Loop Facility, TREE-1144, 1977.

4. Idaho National Engineering Laboratory, Geothermal R\&D Project Report for Period Apriz 1, 1975 to June 30, 1975, ANCR-1247, UC-13, Idaho Falls, Idaho, 1975.

5. U.S. Fish and Wildlife Service, Biologic Values in the Raft River Geothermal Area, Bolse, Idaho, 1976.

6. C. Snow, Fermuginous Ecowk, Buteo regalis, Report No. 13 in Habltat Management Series for Unique or Endangered Species, U.S. Bureau of Land Management, Denver, Colo., 1974.

7: D. R. Ralston, Results of Promp Tests in the Raft River Basin, an open file report to Aerojet Nuclear Company by the Idaho Bureau of Mines and Geology, Moscow, Idaho, 1975, cited in ref. 2.

8. R. W. Atherton et al., "The Analysis of Subsidence Associated with Geothermal Development," vol. 1, NSF Grant No. AER75-17298, Systems Control, Inc. Palo Alto, Calif., 1976.

9. B. E. Lofgren, Land Subsidence and Tectonism, Raft River Valiey, Idaho, U.S. Geological Survey Open File Report 75-585, Sacramento, Calif., 1975.

10. B. E. Lofgren (U.S. Geological Survey, Sacramento, Calif.), personal communication to W. P. Staub (Oak Ridge National Laboratory), September 1977. 


\section{$93 / 94$}

11. R. Stoker (Idaho National Engineering Laboratory), personal communication to W. P. Staub (Oak RIdge National Laboratory), June 1977.

12. D. M. Evans, "Man-made Earthquakes in Denver," Geotimes 10:11-18 (1966).

13. D. Miller, Suggested Practices for Raptor Protection on Powerlines, Edison Electric Institute, 1975.

14. G. Hannum, W. Anderson, and M. Nelson, "Power Lines and Birds of Prey," paper presented at the Northwest Electric Light and Power Observation Conference, Yakima, Wash., 1974.

15. Wayne R. Knowles (Senior Project EngIneer, Geothermal Energy Branch, Department of Energy, Idaho Operations Office), letter to B. G. Arnold (Oak Ridge National Laboratory), April 1978.

16. H. E. Christensen and T. T. Luginbyhl (Eds.), Registry of Toxic Effects of Chemical Substances, National Institute for Occupational Safety and Health, U.S. Dept. of Bealth, Education, and Welfare, Rockville, Md., 1976. 
4. COORDINATION WITE FEDERAL, STATE, AND LOCAI PIANS

The Idaho National Englneering Laboratory has maintained reguler consultation with the Burley District of the Bureau of Land Management (BLM), the U.S. Geological Survey, the Idaho Dept. of Water Resources, the Idaho Dept. of Health and Welfare, and the State Historical Society. The BLM Burley District has in turn consulted with the U.S. Fish and Wildilfe Service concerning biological values of the valley (Appendix A). The district office of the Soil Conservation Service, U.S. Dept. of Agriculture was consulted concerning prime and unique farmland. Numerous other contacts have been made with state and Federal fish and wildife, enviromental, and other agencies. The Cassis County commissioners have been notified at varlous stages in the project. The results of these consultations, including recommendations for mitigation, are discussed under the Individual aress of concern in Sect. 3. None of the concerns expressed by the agencies consulted would prevent or serlously impede development of the project. The status of necessary permits and approvals is summarized in Table 4.1. 
Table 4.1. Permits and approvels

\begin{tabular}{|c|c|c|c|}
\hline Permit or approval & Ageney & Authority. & Status \\
\hline $\begin{array}{l}\text { Exemption from Permit to } \\
\text { Construct and notification } \\
\text { of anticipated start-up } \\
\text { for pilot plants }\end{array}$ & $\begin{array}{l}\text { Idaho Department of } \\
\text { Health and Welfare, } \\
\text { Division of Environ- } \\
\text { ment }\end{array}$ & $\begin{array}{l}\text { Environmental Protection } \\
\text { and Health Act of } 1872 \\
\text { (Rules and Regulations } \\
\text { for Control of Air Pol- } \\
\text { lution in Idahol }\end{array}$ & Will be applied for \\
\hline $\begin{array}{l}\text { Permit to drill ar alter } \\
\text { well on Federal tands }\end{array}$ & $\begin{array}{l}\text { Department of the } \\
\text { Interior }\end{array}$ & $\begin{array}{l}\text { Geothermal Steam Act of } \\
1870\end{array}$ & Obtained \\
\hline $\begin{array}{l}\text { Geothermal Resource Well } \\
\text { Permit (to construct or } \\
\text { atter well or injection } \\
\text { well) }\end{array}$ & $\begin{array}{l}\text { Idaho Department of } \\
\text { Water Resources }\end{array}$ & $\begin{array}{l}\text { Idaho Geothermal Re- } \\
\text { sources Act of } 1972\end{array}$ & Obtained \\
\hline $\begin{array}{l}\text { Application to appropriate } \\
\text { public water (If well in } \\
\text { volves consumptive use of } \\
\text { water, this application must } \\
\text { accompany application for } \\
\text { well permit.) }\end{array}$ & $\begin{array}{l}\text { Idaho Departiment of } \\
\text { Water Resources }\end{array}$ & $\begin{array}{l}\text { Idaho Geothermal Re- } \\
\text { sources Act of } 1972\end{array}$ & $\begin{array}{c}\text { Obtained } \\
\therefore\end{array}$ \\
\hline $\begin{array}{l}\text { Approval of plans for } \\
\text { eanitary and drinking } \\
\text { water ovstems }\end{array}$ & $\begin{array}{l}\text { State Board of } \\
\text { Health }\end{array}$ & $\begin{array}{l}\text { Environmental Protection } \\
\text { end Health Act of } 1872\end{array}$ & Obtained \\
\hline $\begin{array}{l}\text { Approval of Building Plans } \\
\text { (plans must meet codes): } \\
\text { approval for hauling wide } \\
\text { loads on county roads }\end{array}$ & $\begin{array}{l}\text { Cussis County } \\
\text { Commissioners }\end{array}$ & & Will be obtained \\
\hline $\begin{array}{l}\text { Approval for houling wide } \\
\text { loads on state highways }\end{array}$ & $\begin{array}{l}\text { Idaho Transportation } \\
\text { Department }\end{array}$ & . & One day approva! \\
\hline $\begin{array}{l}\text { Withdrawal of } 5000 \text { ecres } \\
\text { from public domain }\end{array}$ & $\begin{array}{l}\text { Bureau of Land } \\
\text { Managemem }\end{array}$ & $\begin{array}{l}43 \text { CFR Part } 2350 \text { and } \\
\text { Executive Order } 10355 \\
\text { (May 26, 1952) }\end{array}$ & In process \\
\hline $\begin{array}{l}\text { Approval of zoning changes } \\
\text { end approval for access } \\
\text { roads }\end{array}$ & $\begin{array}{l}\text { Cassia County } \\
\text { Commissioners }\end{array}$ & $\begin{array}{l}\text { Local Planning Act of } \\
1975\end{array}$ & 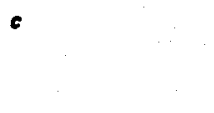 \\
\hline $\begin{array}{l}\text { Approval of sanitary } \\
\text { system }\end{array}$ & $\begin{array}{l}\text { District Health } \\
\text { Department }\end{array}$ & & Will be obrained \\
\hline $\begin{array}{l}\text { Archaeological clearance survey } \\
\text { of lends to be disturbed }\end{array}$ & $\begin{array}{l}\text { Department of the Interior } \\
\text { (through state } \\
\text { archseologist) }\end{array}$ & $\begin{array}{l}\text { Executive Order } \\
11593 \text { (1971) }\end{array}$ & Completed \\
\hline Geothermal injection sgreement ${ }^{f}$ & $\begin{array}{l}\text { Idaho Department of } \\
\text { Water Resources, with } \\
\text { review by Idaho Depart- } \\
\text { ment of Health and } \\
\text { Walfere }\end{array}$ & $\begin{array}{l}\text { Title } 39 \text { Chapter 1, } \\
\text { Chapte: } 52 \text { of Idaho } \\
\text { Code; Chapter 87, Idaho } \\
\text { Session Lows 1973; } \\
\text { Idaho Waste Disposal } \\
\text { Well Act }\end{array}$ & Will be obtained \\
\hline Geothermal production agreement & $\begin{array}{l}\text { Idaho Department of } \\
\text { Water Resourtes }\end{array}$ & $\begin{array}{l}\text { Title } 42 \text { Chapter } 40 \text { of } \\
\text { Idaho Code }\end{array}$ & Will be obtained \\
\hline Permit to alter stream channep & $\begin{array}{l}\text { Idaho Department of } \\
\text { Water Resources }\end{array}$ & $\begin{array}{l}\text { Title } 42 \text { Chapter } 38 \text { of } \\
\text { Idaho Code }\end{array}$ & Will be obtained \\
\hline $\begin{array}{c}\text { Approval of water supply ovstems } \\
\ldots\end{array}$ & $\begin{array}{l}\text { Idaho Department of } \\
\text { Health and Welfare } \\
\text { and District Health } \\
\text { Department }\end{array}$ & & Will be abtained \\
\hline
\end{tabular}

-Pilot plant is one from which the sale of producs is incidental and in developmental quamities. Written approval must be renewed ennually.

BLLM may impose restrictions on the land use under authority of the Geothermal Steam Act of 1970 at the time of transfer.

"Cassia County has not yot established a land use plan.

¿Does not include reservoir tests.

- Required for any channel crossing of the Raft Fiver. 


\section{ALTERNATIVES}

The reasonably avallable alternatives to the proposed action may be categorized as project alternatives and design alternatives. The project alternatives Include no action and delayed action. The design alternatives include changes in location, system design, and condenser cooling.

\subsection{PROJECT ALTERNATIVES}

The reasonably available alternatives of delaying or not constructing the proposed facility were evaluated in the context of the National Geothermal Research and Development Act of 1974. Under this act, the Federal government is called upon to assist in the development of practicable means of producing energy from geothermal resources by supporting resource assessment and research and development profects. If the proposed project is delayed or not constructed, important information on extracting energy from geothermal not become available, to the Industry for several years. Since a large percentage of the Known Geothermal Resource Areas in the United States are within the temperature range of the proposed pilot plant, the development of a substantial amount of the total geothermal resource base w1ll be precluded until research such as this project is conducted. It was therefore concluded that delay or no action is not consistent with the National Geothermal Research and Development Act and subsequent policy resulting from it.

\subsection{DESIGN ALTERNATIVES}

The design alternatives reasonably avallable are restricted by several external constraints. These include the temperature of the resource, the availability of data on the resource, the ability to use existing geothermal wells, the type of research date needed, and the life-cycle costs of the project. 
The binary cycle system for extracting energy frow the geothermal fluid was selected since the binsry cycle w1ll be the most likely comercial method of producing electricity from geothermal fiuids in this temperature range. The system was designed to handle several binary fluids during the faclifty life, although isobutane will be the fluid for inttial operation experiments. This project w1ll therefore have the potential for providing important information on the use of several binary cycle fluids in extracting energy from moderatetemperature geothermal flulds.

The most important alternative from the environmental viewpoint would be a change in the type of cooling system employed because of the water appropriation limits in the Raft River Valley. Alternative cooling wethods that were considered for the project include:

1. air cooling (dry towers),

2. wet cooling tower using geothermal fluid for makeup,

3. wet cooling tower using cool groundwater for makeup, and

4. once-through cooling using cool groundwater.

of these alternatives only dry towers or wet towers with geothermal makeup meet the envirommental and legal constraints on water use; of these two the wet towers are the more cost-effective and were chosen. Other cooling systems such as soll cooling w11l be tested in confunction with operation of the pilot plant.

REFERENCE FOR SECTION 5

1. D. E. White and D. L. Williams (Eds.), Assessment of Geothermal Resources of the United States - 1975, USGS Circular 726, 1975. 
APPENDIX A 



\section{Memorandum}

: Nick Cozakos, District Manager. BLM, Burley District Dffice

DATE: June 24, 1976

FROM : Richard J. Fisher, Field Supervisor, ES, Boise

subject: Biological values in the Raft River Valley Geothermal Lease Area.

The U.S. Fish and Wildlife Service, in response to a meeting with Jim Pribble on June 12, 1975, presents the following concerns with regards to potential impacts on fish and wildlife resources from geothermal exploration and development.

This document serves es a compilation report of wildlife values found within Cassia County, Idaho, geothemal lease areas. The report covers locations of critical habitat areas, vulnerable drainage courses and recomended exclusion areas.

Lands:

The Raft River geothermal lease lands include:

1. Known Geothermal Resource Areas (including the Energy Research. Development Agency (ERDA) withdrawal lands).

T. 13 S., R. 26 E., B.M. Section 35.

T. 14 S., R. 26 E., B.M. Sections 12, 13, 24, 25, 28, 30, 29, 33 , and 36 .

T. 14 S., R. 27 E., B.M. Sections $18,19,30$, and 31 .

T. 15 S., R. 26 E., B.M. Sections 1, 2, 3, 4, 10, 11, 12, 14, $15,16,21,22,23,26,27,28,29,33,34$, and 35 .

T. 15 S., R. 27 E., B.M. Sections 6, 7, 18, 19, 30, and 31 .

T. 16 S., R. 26 E., B.M. Sections 4 and 5.

2. Non-competitive Geothermal Resource Areas (including ERDA withdrawal lands).

T. 11 S., R. 25 E., B.M. Sections 13, 14, 23, and 24.

T. 12 S., R. 26 E., B.M. Sections 15, 22, 26, 27, 34, and 35 . 
T. 13 S., R. 26 E., B.M. Sections 2, 3, 10, 15, 21, 25, 26, 27. 28,33 , and 34 .

T. 13 S., R. 27 E., B.M. Sections 14, 23, 25, 26, 34, and 35.

T. 14 S., R. 26 E., B.M. Sections $3,4,5,6,7,8,9,10,15$, $16,17,18,19,20,21,22,27,31,32$, and 34 .

T. 14 S., R. 27 E., B.M. Sections $1,2,3,4,9,13,14,21$, $23,24,25,26,28,29,32,33$, and 35 .

T. 15 S., R. 26 E., B.M. Sections $5,6,7,8,9,18,19$, and 20.

T. 15 S., R. 27 E., B.M. Sections $2,3,4,5,8,9,10,11,13$, $14,15,17,20,21,22,23,26,27,28,29,32$, and 35 .

T. 16 S., R. 26 E., B.M. Sections $1,2,8,9,10,11,12,13$, 14,15 , and 17 .

T. 16 S., R. 27 E., B.M. Sections $1,2,5,6,7,8,11,14,17$, and 18.

3. ERDA Withdrawal Lands (not included under 1 or 2 above).

T. 13 S., R. 26 E., B.M. Section 36.

T. 13 S., R. 27 E., B.M. Section 31.

T. 14 S., R. 26 E., B.M. Sections 1, 2, 11, 14, 23, 26, and 35.

T. 14 S., R. 27 E., B.M. Sections 6 and 7.

T. 15 S., R. 25 E., B.M. Sections 34, 35, and 36.

T. 15 S., R. 26 E., B.M. Sections $13,24,25,31,32$, and 36.

T. 16 S., R. 25 E.,.B.M. Sections 10, 11, and 12.

T. 16 S., R. 26 E., B.M. Section 3.

\section{Vegetation:}

Four dominant vegetation complexes are found throughout most of the Raft River Valley and Marsh Creek areas. They include:

1. Desert shrub representatives, such as grease wood, (Sarcobatus vermiculatus); shadescale, (A triplex confertifolia); big sage, (Artimisia tridentata); and bus sage, (Artimisia spinescens). 
2. Crested wheatgrass, (Agropyron cristatum); in various stages of reversion to sagebrush.

3. Juniper forests. (Juniperus osteosperma).

4. Alfalfa fields and some cereal crops. Numerous areas are also characterized by halogetin. (Halogeton glomeratus).

Raft River, Cassia and Marsh Creeks:

Beginning at Boise Meridian, T. 13 S., R. 26 E., Sec. 36 and for 19 miles upriver to T. 16 S., R. $25 \mathrm{E}$., Sec. 3, the Raft River flows through the middle of the KGRA lands. Downstream 26 mfles, the river empties into the Snake River at Lake Walcott.

Though a poor fishery is found within this reach of the Raft River, Cassia Creek, a tributary, provides a good fishery and is stocked regularly by the Idaho Department of Fish and Game. Riparian habitat is more extensive on Cassia and Marsh Creek than Raft River; however, all provide cover and nesting habitat for various species of mamma is and birds. Cover use is made by deer, predators, pheasants and waterfow when seeking water. No specific area along these streams concentrates this usage. Riparian vegetation includes bulrush, Scirpus; willow. Salix; and cattails, Typhe.

Though flow through Raft River and Marsh Creek may be as low as 1 to $8 \mathrm{cfs}$, these streams are particularly important to wildlife species in this arid environment. Blowouts and other mishaps which result in the addition of poor quality geothermal fluids to either stream could have a significant impact on the aquatic and wildlife resources of the Raft River area and may also affect water quality downstream in the Snake River. Therefore, all drilling and development should be prohibited within 100 yards of each of these streams.

Deer, partridge, doves, pheasant, waterfowl and many non-game species utilize springs and reservoirs for food, cover and water in the Raft River Valley. Protection of these water sources is of utmost importance to the fauna of this ecosystem due to limited access and the arid nature of the region. A minimum 100 yard radial buffer zone should be maintained around each water source where no wildlife obstructions or vegetative stripping would be permitted. No permanent developments or structures should be built within 100 yards of these water sources. Existing streams should have a 50 yard buffer zone on each side maintained in a natural state of vegetation. Deer, cottontail rabbits, upland game and many non-game animals utilize these corridors for food, cover and water. Important streams, reservoirs and springs are indicated in blue on the map. 
EXISTING SPRINGS AND RESERVOIRS WHERE A MINIMUM 100 YARD RADIAL BUFFER ZONE SHOULD BE MAINTAINED

NAME

West Bridge Spring
Keisaw Reservoir
Reservoir
Sandrock Well
Parks Creek Reservoir
Nibbs Reservoir
"Mu Reservoir
McClellans Spring
Spring

T. 15 S., R. 25 E., Sec. 18

T. 15 S., R. 27 E., Sec. 23

T. 14 S., R. 26 E., Sec. 33

T. 14 S., R. 27 E., Sec. 27

T. 13 S., R. 26 E., Sec. 28

T. 13 S., R. 26 E., Sec. 9

T. 13 S., R. 26 E., Sec. 4

T. 13 S., R. 26 E., Sec. 3

T. 15 S., R. 26 E., Sec. 8

Existing streams where a 50 yard buffer zone should be maintained.

West Bridge Spring

R. 26 E., T. 15 S., Sec. 18, 17, 16, 22.

Spring Creek

R. 26 E., T. 14 S., Sec. $19,20,21,22,15,14,13,12$.

Nibbs Creek

R. 26 E., T. 13 S., Sec. 6, 5, 9, 10.

Unnamed creek

R. 26 E., T. 12 S., Sec. $20,29,28,27,26$.

\section{Wildlife Concerns:}

The Raft River and Marsh Creek drainages support a diversity of wildlife, and the following areas have special significance in maintaining this diversity.

Deer are found utilizing nearly every canyon and gully along the eastern front of the Jim Sage Mountains. Important deer winter habitat is available along Marsh Creek. Efforts should be taken to minimize vegetative disturbance throughout the year during the exploratory phase. By controlling legetative destruction, the geothermal resource may be 
evaluated and its potential determined without long-term disturbance to the deer population. This is appropriate where bitterbrush, (Purshia); willow, (salix): and cliffrose. (Cowania): are found in stands of more than five acres.

There is remnant herd of antelope that utilizes the lower portions of the western and eastern slopes of Raft River Valley. Kidding areas for this herd are primarily found south of the valley around the Raft River Mountains. If information is not avallable on the location of these kidding areas, we should enter into cooperative study to determine this. Once located, surveying should be prohibited within 1/4 mile of the kidding area from the ist of May through June. No permanent developments or vegetative removal should be allowed in these areas.

Sage grouse strutting grounds are located in:

T. 14 S., 26 E., Sec. 30 and 34 .

T. 15 S., 26 E., Sec. 3 (See map).

Section 4 in T. 15 S., 26 E., supports a wintering area for sage grouse that may also be strutting ground. The critical areas listed above will be checked for population characteristics and their use verified in the field this summer and next spring (1977), through a cooperative study involving BLM and the Idaho Department of Fish and Game and this agency. It is known that female grouse move to sagebrush habitat for nesting sites and most nesting occurs within approximately two miles of the strutting grounds. The approximate area required for the nesting complex of these grouse are delineated by red slash marks on the attached map. Surface activity should be restricted from this area between March 15 and July 15. In addition, no permanent structures should be built within one mile of the strutting grounds.

Raptorial birds are found in moderate numbers through the lease areas. Their prey base of jackrabbits, cottontails, ground squirrels, small rodents and reptiles are moderately abundant also. A Townsend ground squirrel colony is present in:

T. 14 S., R. 27 E., Sec. 22 and 27.

The Townsend ground squirrel is a major prey species for raptors nesting on the west side of the Blackpine Mountains, especially during years of low jackrabbit abundance. No surface disturbance should be allowed within those areas where ground squirrels are found and 100 yard buffer zone of no development should be established around the colony (See map).

The ferruginous hawk, perhaps the most numerous raptor in Raft River, is found nesting throughout the lease area in junipers and, in two 
instances, on the ground. The Raft River Valiey has the greatest density of this species within the state. The species is classified by the U.S. Fish and Wildlife Service as a species of concern and is a possible candidate for threatened status. Ferruginous hawks are very sensitive to disturbance during the nesting period and will readily abandon the effort. It is recomended that:

1. A one-half mile radial buffer zone be located around nests where surface disturbance will not be allowed.

2. Up to an additional half-mile zone be established where surface. disturbance including surveys or drilling will not be allowed from March 1 to July 15.

Recommendation 1 would maintain the nest site and hunting habitat around the nest. Radical alteration can cause returning adult birds to abort nesting activities. Recomendation 2 is made to maximize the probability that the adults will successfully nest and fledge young and to minimize the influence of human disturbance as it relates to raptor productivity. Also, the additional half-mile is recommended to insure that fledgings will have sufficient cover and food adjacent to the nest. The March 1 through July period represents the time span in which adults first arrive in the area through the period that the young fledge and spend one to two weeks in the vicinity of the nest. This period is necessary to assure the full nesting sequence. The nests should be checked annually during the month of April to determine which are active. To be specific, some pairs will use one nest site year after year while, other pairs will nest only during years when there is a high density of jackrabbits. Surveying could be allowed near nests not being utilized that particular year.

Approximately 31 nest sites are known to be active within the last four years in and around the periphery of the lease areas. The nest site areas are listed below and buffer zones are inscribed on the enclosed map.

\section{NEST LOCATIONS}

T. 11 S., R. 26 E., B.M. Section 29

T. 12 S., R. 26 E., B.M. Section 22

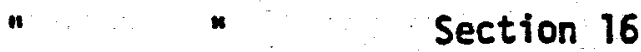

T. 13 S., R. 26 E., B.M. Section 3

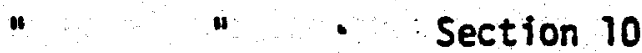

T. 13 S., R. 28 E., B.M. Section 32 
T. 14 S., R. 26 E., B.M. Section 1

T. 14 S., R. 26 E., B.M. Section 9

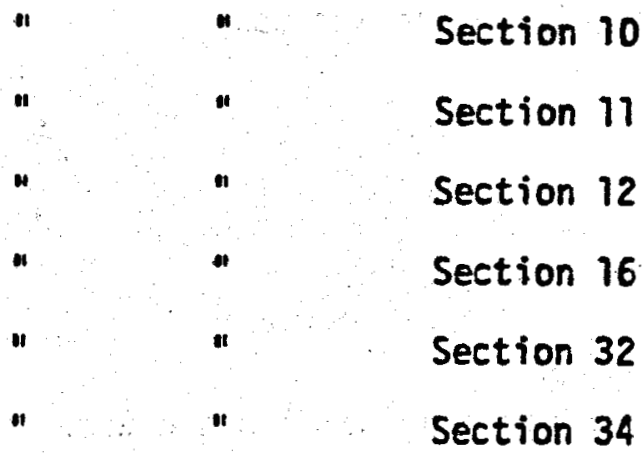

T. 14 S., R. 27 E., B.M. Section 33

u.

"

Section 36

T. 14 S., R. 28 E., B.M. Section- 5

I $\quad$ a

แ

"

$"$ $\mathbf{a}$

แ

a

Section 7

Section 19

Section 30

Section 31

T. 15 S., R. 26 E., B.M. Section 15

u

"

Section 16

"

"

Section 33

T. 15 S., R. 28 E., B.M. Section 7

, II

*

Section 20

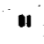

Section 32

T. 16 S., R. 24 E., B.M. Section 24 (two nests)

T. 16 S., R. 24 E., B.M. Section 22

T. 16 S., R. 24 E., B.M. Section 23 
We hope this information will be useful to you in establishing guidelines for geothermal activities on the Raft River lands. If you have further questions, please contact us.

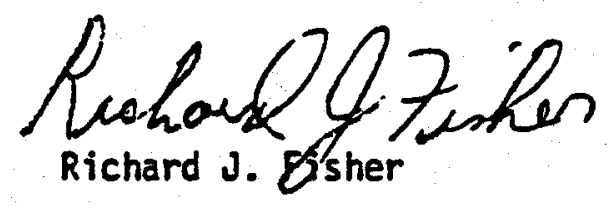

Enclosure

CC: Bill Webb

Idaho Department of Fish and Game

Les Dauterive

U.S. Geological Survey 
valley. 2 The respondente ( $13 \%$ of the membership) were overwhelmingly in favor of the geothermal project. Concerns expressed in the questionnaire responses included: (1) avallabllity of housing and location of new housing, (2) preservation of the friendiy feeling of a close commuity, (3) preservation of the rural character of the valley, and (4) preservation of the natural enviroment. These and other enviromental issues are discussed below in Chap. 3 .

\section{REFERENCES FOR SECTION 1}

1. Wayne R. Knowles (Senior Project Engineer, Geothermal Energy Branch, Department of Energy, Idaho Operations Office), letter to H. G. Arnold (Oak Ridge Netional Laboratory), Apr1l 1978.

2. J. A. Goodnight, Commuity Impact Assessment of a Diversified Geothermal Energy Project Proposed for the Raft River Valley, Idaho, Battelle Memorial Institute, Pacific Northwest Division, Seattle, Wash., 1977. 